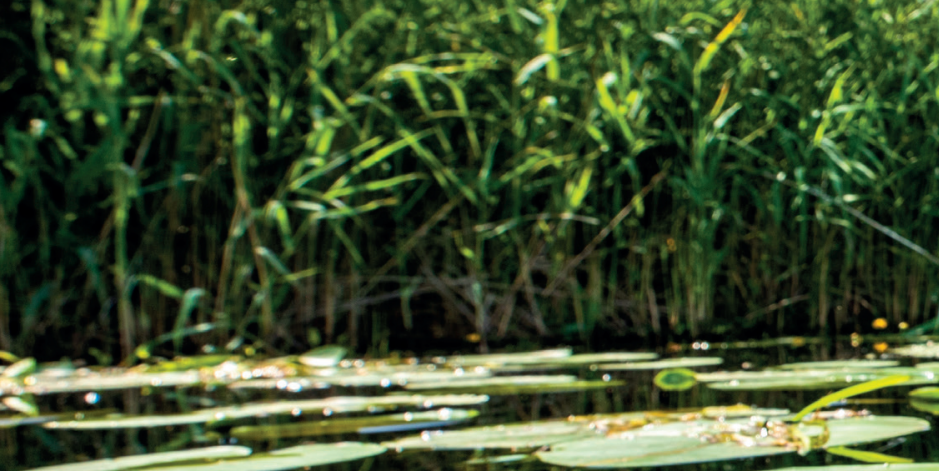
198.

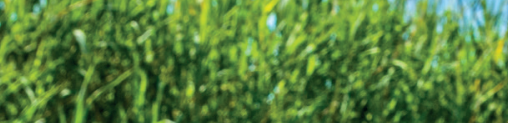
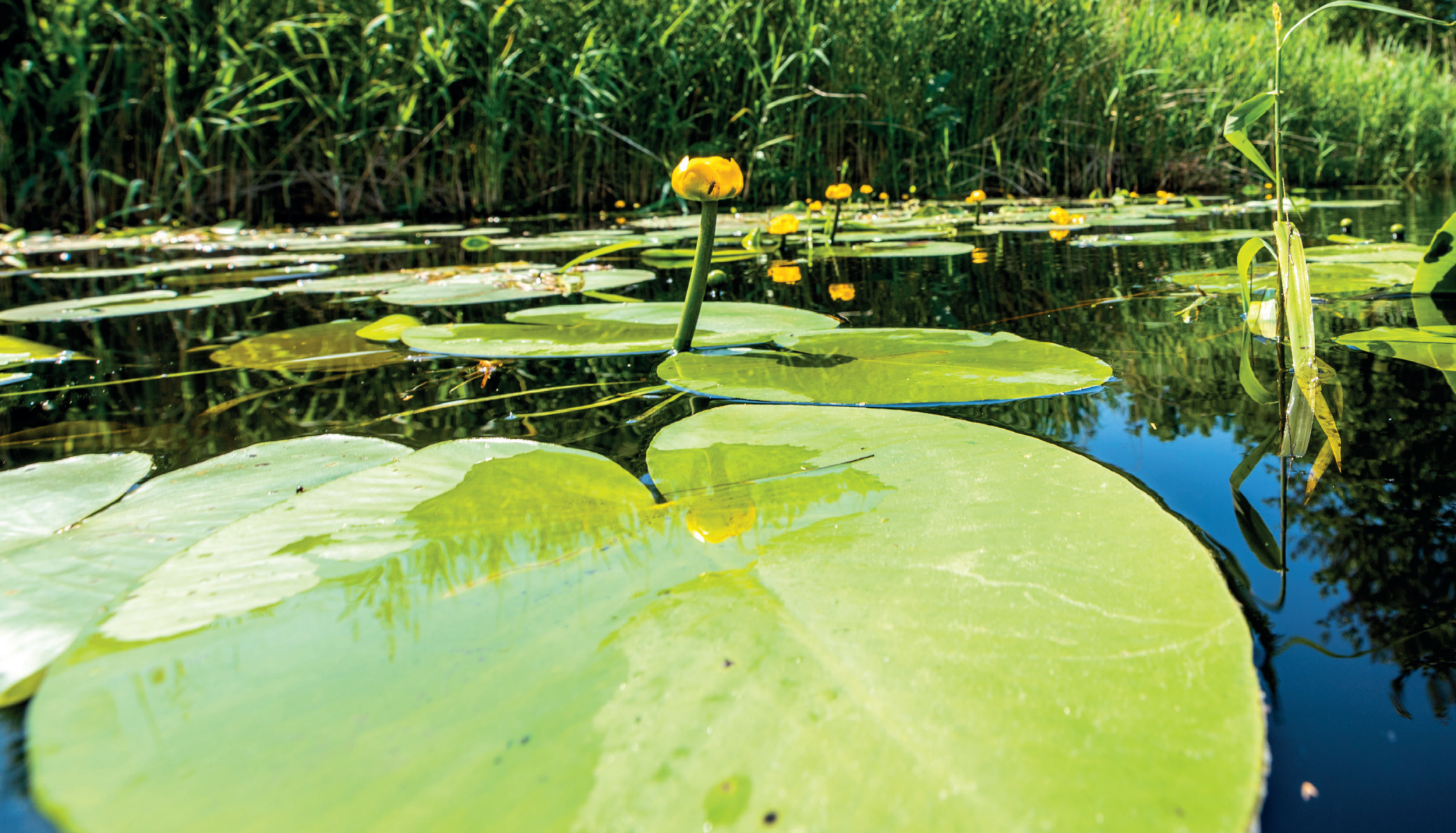

\title{
.
}





\section{Regionale pilot Kennisimpuls RBO-Noord, synthese uit- en afspoeling stikstof en fosfor naar water}

Peter Schipper ${ }^{1}$, Robert Smit ${ }^{1}$, Rene Rietra ${ }^{1}{ }^{\text {Luuk van Gerven }}{ }^{1}$, Leo Renaud ${ }^{1}$, Leonne Jeurissen ${ }^{1}$, Gerard H. Ros ${ }^{2}$

1 Wageningen Environmental Research

2 Nutriënten Management Instituut (NMI)

Wageningen Environmental Research

Wageningen, juni 2021

Gereviewd door:

Laura Timmermans, Wageningen Environmental Research

Akkoord voor publicatie:

Gert-Jan Reinds, teamleider Duurzaam Bodemgebruik WEnR

Rapport 3094

ISSN 1566-7197 
Schipper P., R. Smit., R. Rietra., L. Renaud, G.H. Ros, 2021. Regionale pilot Kennisimpuls RBO-Noord, synthese uit- en afspoeling stikstof en fosfor naar water. Wageningen, Wageningen Environmental Research, Rapport 3094. 62 blz.; 25 fig.; 6 tab.; 51 ref.

Bekend is dat de omvang van de verschillende nutriëntenbronnen in Nederland verschilt per regio/locatie en in tijd, en dat de mate van stuurbaarheid van de emissiereductie niet altijd goed bekend is. Hierdoor staan ecologische doelen en maatregelen om de ecologische doelen te bereiken vaak ter discussie. De bestuurders van Regionaal Bestuurlijk Overleg Noord (RBO Noord) vragen een samenvatting van recente studies over de problematiek van de diffuse nutriëntenbronnen in de beheergebieden van Wetterskip Fryslân, Noorderzijlvest en Hunze en Aa's. Ook wordt gevraagd om een overzicht van de water- en stofstromen vanwege het huidige beleid (Delta-aanpak Waterkwaliteit en Zoetwater) en de daarin benoemde hardnekkige problemen met nutriënten. Het huidige rapport geeft een synthese van de actuele kennis over af- en uitspoeling vanuit natuur- en landbouwbodems naar water. De resultaten hiervan geven a) inzichten in de huidige situatie en handelingsperspectieven voor de overheden en waterbeheerders en $b$ ) de benodigde inputdata om via een oppervlaktewaterkwaliteitsmodel de wateren stofstromen in Noord-Nederland dynamisch te kunnen simuleren.

Trefwoorden: Kaderrichtlijn Water, oppervlaktewater kwaliteit, uitspoeling, afspoeling, landbouw, bronnenanalyse, nutriëntenbalans, mestgiften, herkomst nutriënten, stikstof, fosfor, nitraat

Dit rapport is gratis te downloaden van https://doi.org/10.18174/549304 of op www.wur.nl/environmental-research (ga naar 'Wageningen Environmental Research' in de grijze balk onderaan). Wageningen Environmental Research verstrekt geen gedrukte exemplaren van rapporten.

2021 Wageningen Environmental Research (instituut binnen de rechtspersoon Stichting Wageningen Research), Postbus 47, 6700 AA Wageningen, T 03174807 00, www.wur.nl/environmental-research. Wageningen Environmental Research is onderdeel van Wageningen University \& Research.

- Overname, verveelvoudiging of openbaarmaking van deze uitgave is toegestaan mits met duidelijke bronvermelding.

- Overname, verveelvoudiging of openbaarmaking is niet toegestaan voor commerciële doeleinden en/of geldelijk gewin.

- Overname, verveelvoudiging of openbaarmaking is niet toegestaan voor die gedeelten van deze uitgave waarvan duidelijk is dat de auteursrechten liggen bij derden en/of zijn voorbehouden.

Wageningen Environmental Research aanvaardt geen aansprakelijkheid voor eventuele schade voortvloeiend uit het gebruik van de resultaten van dit onderzoek of de toepassing van de adviezen.

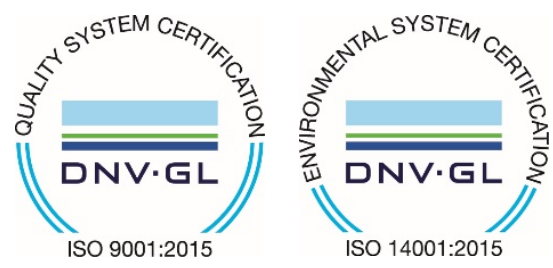

Wageningen Environmental Research werkt sinds 2003 met een ISO 9001 gecertificeerd kwaliteitsmanagementsysteem. In 2006 heeft Wageningen Environmental Research een milieuzorgsysteem geïmplementeerd, gecertificeerd volgens de norm ISO 14001.

Wageningen Environmental Research geeft via ISO 26000 invulling aan haar maatschappelijke verantwoordelijkheid.

Wageningen Environmental Research Rapport 3094 | ISSN 1566-7197

Foto omslag: Daniël Hartog 


\section{Inhoud}

$\begin{array}{ll}\text { Verantwoording } & 5\end{array}$

$\begin{array}{ll}\text { Woord vooraf } & 7\end{array}$

$\begin{array}{ll}\text { Samenvatting } & 9\end{array}$

1

Inleiding

1.1 Aanleiding 11

1.2 Doel $\quad 12$

$\begin{array}{lll}1.3 & \text { Werkwijze } & 12\end{array}$

$\begin{array}{lll}1.4 & \text { Leeswijzer } & 12\end{array}$

2.1 Beschouwde studies 13

2.2 Analyse van de beschouwde studies $\quad 14$

2.2.1 Inzicht op basis van procesmodellen 14

2.2.2 Inzicht op basis van data en praktijkkennis $\quad 17$

2.2.3 Inzicht op basis van statistische modellen 18

$\begin{array}{lll}2.3 & \text { Uit- en afspoeling studiegebied } & 20\end{array}$

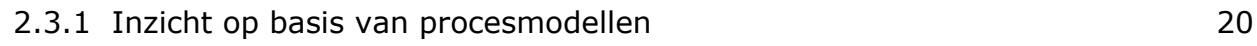

2.3.2 Inzicht op basis van data en praktijkkennis $\quad 23$

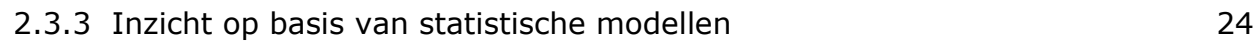

$\begin{array}{lll}2.4 & \text { Aandachtspunten } & 28\end{array}$

$3 \quad$ Modelberekeningen af- en uitspoeling $\quad 30$

$\begin{array}{lll}3.1 & \text { Inleiding } & 30\end{array}$

3.2 Regionalisatie (herschikken) rekenplots 30

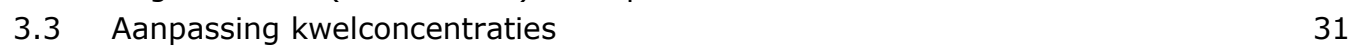

3.4 Modellering oppervlakkige afspoeling fosfor 32

3.5 Gecombineerde modelresultaten af- en uitspoeling 36

$\begin{array}{lll}3.6 & \text { Aansluiting op waterkwaliteitsmodel SOBEK } & 39\end{array}$

$\begin{array}{lll}4.1 & \text { Maatregelen landbouwgronden } & 40\end{array}$

4.2 Uitgangspunten en methodiek berekeningen bufferstroken 41

4.3 Toepassingsgebied en breedte bufferstroken 43

$\begin{array}{lll}4.4 & \text { Zuiverende werking bufferstroken } & 44\end{array}$

$5 \quad$ Conclusies en aanbevelingen $\quad 47$

$\begin{array}{lll}5.1 & \text { Conclusies } & 47\end{array}$

$\begin{array}{lll}5.2 & \text { Aanbevelingen voor vervolgstudies } & 48\end{array}$

$\begin{array}{lll}5.3 & \text { Aanbevelingen voor maatregelen } & 48\end{array}$

5.3.1 Handvatten voor haalbaarheid KRW-doelen 48

5.3.2 Handvatten voor ondersteunen DAW-spoor 50

5.3.3 Relaties met overige beleidsthema's $\quad 50$

$\begin{array}{ll}\text { Literatuur } & 53\end{array}$

$\begin{array}{llr}\text { Bijlage } 1 & \text { Toelichting model STONE } & 56\end{array}$

$\begin{array}{lll}\text { Bijlage } 2 \text { Af- en uitspoeling stikstof en fosfor vanaf landbouwgronden } & 58\end{array}$ 



\section{Verantwoording}

Rapport: 3094

Projectnummer: 5200045554

Wageningen Environmental Research (WENR) hecht grote waarde aan de kwaliteit van zijn eindproducten. Een review van de rapporten op wetenschappelijke kwaliteit door een referent maakt standaard onderdeel uit van ons kwaliteitsbeleid.

Akkoord Referent die het rapport heeft beoordeeld,

functie: $\quad$ Senior onderzoeker

naam: Laura Timmermans, Wageningen Environmental Research

datum: $\quad$ Mei 2021

Akkoord teamleider voor de inhoud,

naam: Gert Jan Reinds

datum: Juni 2021 


\section{Woord vooraf}

De Europese Kaderrichtlijn Water (KRW) schrijft voor dat het oppervlaktewater in 2027 voldoende schoon en ecologisch gezond is. De belasting van oppervlaktewateren met nutriënten vormt en veel waterlichamen een belemmering. De bestuurders van het Regionaal Bestuurlijk Overleg RijnNoord/Nedereems willen beter inzicht in de water- en nutriëntenstromen van de boezem en daarop aangesloten hoofdwatergangen en in effecten van maatregelen die de nutriëntenbelasting kunnen verlagen. De waterbeheerders hebben de Kennisinstituten Deltares en Wageningen Environmental Research (WEnR) gevraagd om een bronnenanalyse voor stikstof en fosfor uit te voeren en daarbij zo optimaal mogelijk gebruik te maken van data, informatie en modellen. Deze bronnenanalyse is uitgevoerd in het kader van een pilot ten behoeve van de Kennisimpuls Waterkwaliteit ${ }^{1}$.

Voor de bronnenanalyse is een gebiedsdekkend oppervlaktewatermodel (kwantiteit en kwaliteit) opgezet voor de gekoppelde boezemsystemen van de drie waterschappen, Wetterskip Fryslân, Waterschap Noorderzijlvest en Waterschap Hunze en Aa's, met verbindingen met het IJsselmeer, het Lauwersmeer, Waddenzee en Eems en het achterland dat hierop van invloed is. Als onderdeel van deze studie is door WEnR in samenwerking met het Nutriënten Management Instituut (NMI) een synthese uitgevoerd van (model)studies naar de uit- en afspoeling van stikstof en fosfor naar het oppervlaktewater.

Het voorliggende onderzoek beschrijft en integreert de verschillende studies die in de afgelopen jaren zijn uitgevoerd om inzicht te krijgen in de uit- en afspoeling van stikstof en fosfor richting het oppervlaktewater. Voor het onderzoek zijn nieuwe modelberekeningen van de uit- en afspoeling uitgevoerd, ruimtelijk hot-spots in beeld gebracht, effecten van bufferzones berekend en handelingsperspectieven voor landbouwmaatregelen om de uit- en afspoeling te verminderen uiteengezet. De berekende uit- en afspoeling is verwerkt in het oppervlaktewatermodel dat door Deltares met Sobek en Delwaq is opgezet.

Het onderzoek is begeleid door de 3 genoemde waterschappen, Rijkswaterstaat, de provincie Fryslân, Groningen en Drenthe. Tijdens de overleggen is regio specifieke kennis ingebracht en zijn tussenresultaten gepresenteerd en besproken.

\footnotetext{
1 Kennisimpuls Waterkwaliteit is een 4-jarig onderzoeksprogramma, gestart in 2018, om versnipperde kennis over waterkwaliteit bijeen te brengen en beter toepasbaar te maken voor de praktijk; zie: http://www.kennisimpulswaterkwaliteit.nl/nl
} 


\section{Samenvatting}

De nutriëntenbelasting vormt een belangrijke belemmering om ecologische doelen voor het oppervlaktewater te bereiken. De waterbeheerders Noord-Nederland hebben behoefte aan transparant inzicht in de water- en stofstromen van bron tot de emissies van stikstof en fosfor naar de watersystemen die met elkaar in verbinding staan en elkaar beïnvloeden (IJsselmeer, gekoppelde boezemsystemen, Lauwersmeer en Waddenzee). Ook is behoefte aan een synthese van recente studies die naar de uit- en afspoeling van nutriënten naar het oppervlaktewater zijn uitgevoerd. Daartoe is in opdracht van RBO-Noord met subsidie van de Kennisimpuls Waterkwaliteit ${ }^{2}$ een regionale onderzoeks-pilot opgezet. Deze pilot omvat de ontwikkeling van een oppervlaktewatermodel dat de water- en nutriëntenstromen van de boezem en daarop aangesloten hoofdwatergangen simuleert in de beheergebieden van de waterschappen Fryslân, Noorderzijlvest en Hunze en Aa's en onderzoek naar de uit- en afspoeling van stikstof en fosfor naar het watersysteem in NoordNederland. De voorliggende studie beschrijft de resultaten van het onderzoek naar de uit- en afspoeling.

\section{Methode}

Met de methode KRW-ECHO zijn nieuwe modelberekeningen uitgevoerd. De herschikking van de rekenplots van STONE is uitgevoerd voor de 57 afwateringseenheden die voor de modelstudie ruimtelijk zijn gedefinieerd. In de berekeningen is gebruik gemaakt van door het NMI ruimtelijk uitgewerkte informatie over de stikstof- en fosfaattoestand van de landbouwbodems. Met de verkregen inzichten zijn ruimtelijk hot-spots van de uit- en afspoeling van stikstof en fosfor in beeld gebracht, effecten van bufferzones berekend en handelingsperspectieven uiteengezet voor landbouwmaatregelen om de uit- en afspoeling te verminderen uiteengezet. De berekende uit- en afspoeling is verwerkt in het oppervlaktewatermodel dat door Deltares is opgezet.

\section{Synthese studies naar de uit- en afspoeling van stikstof en fosfor}

Studies die uitgaan van statistische benaderingen geven lokaal inzicht in de invloed van nutriëntgehaltes in de bodem, de bemesting en bodemkwaliteit op de variatie in $\mathrm{N}$ - en $\mathrm{P}$-concentraties in het oppervlaktewater. Kennis van het bodem- en watersysteem is hierbij cruciaal om onderscheid te maken tussen causaliteit en correlatie. De mechanistische modellering met STONE biedt onderbouwd inzicht in de relatie tussen de historische en actuele belasting van de bodem, de bodembronnen, geohydrologie en het niveau van de uit- en afspoeling. Door de focus op mechanistische processen kan gericht inzicht worden gegeven in de bijdrage van verschillende bronnen en emissieroutes. Koppeling van de gebruikte brondata, de statistische modellen en het STONE-instrumentarium biedt potentie om op detailniveau inzicht te bieden in de uit- en afspoeling van de nutriënten, maar met de huidige (anno 2021) beschikbare meetgegevens en modelonzekerheden kan dit inzicht alleen op een grover ruimtelijk detailniveau geboden kan worden.

Enkele aandachtspunten die in die studies naar voren zijn gekomen om procesmatig modelonderzoek te verbeteren en verfijnen, zijn verwerkt in de herberekening van de uit- en afspoeling met SWAPAnimo rekenplots van het modelinstrumentarium STONE. Dit betreft de P-toestand van de ondiepe en verbeterde inschattingen van de concentraties van stikstof en fosfor in kwelwater. De berekende uiten afspoeling naar de oppervlaktewateren (water, stikstof en fosfor) zijn voor de periode 2013 tot en met 2017 op decadebasis verwerkt in het oppervlaktewatermodel Sobek-Delwaq dat door Deltares voor de regionale pilot van de Kennisimpuls Waterkwaliteit is opgezet.

\section{Effecten landbouwmaatregelen}

Met het modelinstrumentarium is het effect van droge bufferzones op de uit- en afspoeling berekend. Het resultaat geeft aan dat hiermee de uit- en afspoeling voor stikstof tot maximaal $15 \%$ en fosfor

\footnotetext{
2 De Kennisimpuls Waterkwaliteit is een 4-jarig onderzoeksprogramma dat in 2018 is gestart om de versnipperde kennis over waterkwaliteit bijeen te brengen en beter toepasbaar te maken voor de praktijk. 
maximaal $20 \%$ afneemt. Het effect verschilt sterk per deelgebied, enerzijds door de verschillen in de perceelskenmerken en anderzijds door de aannames dat percelen wel/niet geschikt zijn voor aanleg van een bufferstrook. In de deelstroomgebieden waar is aangenomen dat het merendeel $(>50 \%)$ van de percelen zich leent voor aanleg van een bufferstrook, is berekend dat daar de uit- en afspoeling van stikstof afneemt van 6 tot $11 \%$ en van fosfor van 4 tot 15\%. In de methode is aangenomen dat percelen waar buisdrainage aanwezig er geen bufferstrook wordt aangelegd. Als ook voor die percelen het effect van een bufferstrook wordt berekend, zal ook daar de uit- en afspoeling afnemen, maar zal het effect minder groot zijn in vergelijking met percelen waar geen buisdrainage aanwezig is. Voor (beleids)keuzes over stimulering van bufferzones wordt aanbevolen vooral te kijken in gebieden (percelen) waar relatief grote risico's zijn voor oppervlakkige afstroming van fosfor.

\section{Handelingsperspectieven}

Maatregelen die onderdeel zijn van de Goede Landbouw Praktijk bieden goede handelingsperspectieven om de uit- en afspoeling van stikstof en fosfor naar water te verminderen, omdat dit bijdraagt aan het sluiten van kringlopen en meerwaarde biedt voor de agrariër. Het is daarbij belangrijk om niet alleen te focussen op het agrarische landgebruik (wat gebeurt er op het perceel), maar dat ook gekeken moet worden naar het gehele bodem-watersysteem, inclusief het beheer van sloot(randen). De keuze voor de juiste maatregelen op de juiste plek vereist inzicht in de belangrijkste bronnen en routes van stikstof en fosfaat én de stuurbaarheid ervan. Dit is relevant voor zowel de technische implementaties (waar zijn welke maatregelen zinvol), als de sociale motivatie en het noodzakelijke instrumentarium om veranderingen in beweging te brengen. De resultaten van het onderhavige onderzoek en recent ontwikkelde tools zoals Maatregel-op-de-kaart, de Bedrijfswaterwijzer en het BedrijfsBodemWaterPlan kunnen hier goed bij helpen.

\section{Aanbevelingen}

Op basis van het onderzoek worden aanbevelingen gedaan voor opvolgende (model)studies naar de uit- en afspoeling, monitoring van de grondwaterkwaliteit, en hoogfrequente monitoring debieten en concentraties op belangrijke uitwisselpunten van het oppervlaktewater. Ook worden voor maatregelen om de uit- en afspoeling te verminderen aanbevelingen gedaan en diverse handvaten beschreven om effectieve maatregelen te vinden en stimuleren. 


\section{$1 \quad$ Inleiding}

\section{$1.1 \quad$ Aanleiding}

De Europese Kaderrichtlijn Water (KRW) schrijft voor dat het oppervlaktewater in 2027 voldoende schoon en ecologisch gezond moet zijn. De waterbeheerders maken hiervoor

stroomgebiedsbeheerplannen (SGBP's) waarin ze beschrijven welke maatregelen de waterbeheerders, provincies, gemeenten en derden nemen om deze waterkwaliteitsdoelen te behalen. Bij de uitwerking hiervan wordt actief samengewerkt met agrarische collectieven, LTO-afdelingen en andere agrarische gebiedspartijen binnen het Deltaplan Agrarisch Waterbeheer. Inmiddels bereiden de waterschappen en provincies zich voor op de besluitvorming voor SGBP3 (2022-2027). Te hoge concentraties van stikstof en fosfor vormen een hardnekkig probleem in veel Nederlandse waterlichamen om de KRW-doelen voor een goede ecologische toestand te halen (PBL, 2020).

Een helder zicht op de herkomst en grootte van de problematiek van de diffuse nutriëntenbronnen is belangrijk om richting te geven aan de selectie van de juiste maatregelen binnen het Deltaplan Agrarisch Waterbeheer. Op basis van generieke kennis zijn in 2020 en 2021 door alle waterschappen zogenoemde Gebiedsdocumenten Agrarische Wateropgave opgesteld waarin de belangrijkste knelpunten en doelen alsook het mogelijke handelingsperspectief in beeld worden gebracht. In 2021 worden deze in samenwerking met de agrarische sector vertaald in uitvoeringsprogramma's en concrete bedrijfswaterplannen en wordt de borging van de uitvoering vastgelegd in bestuursovereenkomsten. Bekend is dat de omvang van de verschillende nutriëntenbronnen in Nederland verschilt per regio, locatie en in tijd, en dat de mate van stuurbaarheid van de emissiereductie niet altijd (goed) bekend is. Hierdoor staan ecologische doelen en maatregelen om de ecologische doelen te bereiken continu ter discussie. De bestuurders van RBO Noord hebben aangegeven behoefte te hebben aan een uitlegbaar verhaal ten aanzien van de problematiek van de diffuse nutriëntenbronnen in de beheergebieden van Wetterskip Fryslân, Noorderzijlvest en Hunze en Aa's. Ook vanuit het huidige beleid (Delta-aanpak Waterkwaliteit en Zoetwater) en de daarin benoemde hardnekkige problemen met nutriënten zijn het nut en de noodzaak toegenomen om de water- en stofstromen beter in beeld te kunnen krijgen. Het gaat dan om water- en stofstromen van bron tot emissie naar het oppervlaktewater. In de beheergebieden van RBO Noord betreft het de watersystemen die met elkaar in verbinding staan en elkaar beïnvloeden (IJsselmeer, gekoppelde boezemsystemen, Lauwersmeer en Waddenzee, in de stroomgebieden Rijn en Eems). Afwenteling van nutriënten is een belangrijk onderwerp.

Omdat er de laatste jaren allerlei verschillende rapportages zijn verschenen die inzicht geven in allerlei deelaspecten van deze problematiek, is er behoefte aan een overkoepelend overzicht van de problematiek van de nutriëntenbelasting vanuit diffuse bronnen naar het oppervlaktewater. Een belangrijk aspect hierbij is ook het handelingsperspectief om deze bronnen via agrarische of hydrologische maatregelen zo te beïnvloeden dat de belasting substantieel kan worden verlaagd, juist ook omdat deze potentiële reductie bepaalt welke ecologische kwaliteit nagestreefd moet worden. De waterbeheerders hebben de Kennisinstituten Deltares en WEnR gevraagd om een bronnenanalyse voor stikstof en fosfor uit te voeren en hiervoor een oppervlaktewatermodel te ontwikkelen waarmee de water- en nutriëntenstromen van de boezem en daarop aangesloten hoofdwatergangen transparant in beeld kunnen worden gebracht en effecten van maatregelen op de nutriëntenbelasting kunnen worden doorgerekend. In dit traject is het gewenst om maximaal gebruik te maken van de opgedane kennis vanuit de studies die de afgelopen jaren zijn verricht. Hierdoor wordt inzicht gegeven in de actuele situatie wat betreft de af- en uitspoeling van nutriënten naar het oppervlaktewater, het voorkomen van 'hotspots en hot moments' en het perspectief om deze te beïnvloeden. 


\subsection{Doel}

Omdat het voorkomen van diffuse nutriëntenbelasting sterk samenhangt met de lokale kenmerken van percelen, bedrijven, polders en regio's, is het belangrijk om goed zicht te krijgen op de factoren die van invloed zijn op de af- en uitspoeling van nutriënten. In het bijzonder is dit het geval voor de snelle routes en hotspots die verantwoordelijk zijn voor de belasting van het oppervlaktewater met nutriënten. Dit inzicht is des te meer relevant, omdat de effectiviteit van maatregelen om deze belasting te verlagen ook samenhangt met dezelfde lokale kenmerken. Deze studie beoogt:

- Inzicht te geven in de belangrijkste factoren die de af- en uitspoeling bepalen;

- De af- en uitspoeling vanaf landbouw en natuurbodems naar het oppervlaktewater binnen het beheergebied van de drie noordelijke waterschappen te kwantificeren;

- Inzicht te geven in het effect van maatregelen om de uit- en afspoeling te verminderen.

De opgedane kennis en inzichten worden vervolgens gebruikt in het door Deltares ontwikkelde oppervlaktewatermodel (Boderie et al., 2021). Een inhoudelijk analyse van voorkomende verschillen in landgebruik, bemesting, bodem en gerelateerde emissies tussen betrokken waterschappen is geen onderdeel van deze studie.

\section{$1.3 \quad$ Werkwijze}

Voor de synthese worden recentelijk uitgevoerde studies verzameld en bestudeerd. Op basis hiervan wordt in beeld gebracht welke gebiedskenmerken een belangrijke rol hebben in het voorkomen van stikstof- en fosforemissies naar het oppervlaktewater. De verschillende studies geven inzicht, evenals data en aandachtspunten, om via modellering nog meer grip te krijgen op het ruimtelijk voorkomen van deze nutriëntenverliezen. Deze zijn waar mogelijk verwerkt in een herberekening van de af- en uitspoeling. Met een aparte methode is de oppervlakkige afstroming van fosfor gekwantificeerd, waarin bodemkwaliteitskaarten zijn verwerkt die door het NMI in voorgaande studies op basis van gegevens uit agrarische laboratoria zijn gegenereerd. De berekende af- en uitspoeling is aan Deltares overgedragen op het niveau van de deelstroomgebieden die in het Sobek-model worden onderscheiden. Van de berekende af- en uitspoeling zijn GIS-kaarten vervaardigd die inzicht geven in de hotspots van fosfor en stikstof. Als voorbeeld van een mitigerende maatregel is het effect van bufferstroken op de af- en uitspoeling berekend. Het effect hiervan is met GIS-routines ruimtelijk berekend en omgerekend naar het effect per deelstroomgebied.

\section{$1.4 \quad$ Leeswijzer}

Na deze inleiding volgt in hoofdstuk 2 een analyse van de eerder uitgevoerde studies in het beheergebied van de drie waterschappen in Noord-Nederland. De verschillende studies worden beschreven qua methodiek en de belangrijkste resultaten qua opgedane gebiedsinzichten rond de $\mathrm{N}$ en P-belasting van het oppervlaktewater. Hoofdstuk 2 rondt af met een aantal aandachtspunten die voortkomen uit deze gebiedsstudies, waarmee in het vervolg van de modellering van de water- en stofstromen rekening wordt gehouden. In hoofdstuk 3 wordt vervolgens beschreven hoe het huidige STONE-model is aangepast en uitgebreid om rekening te houden met de opgedane inzichten vanuit de beschreven gebiedsstudies. Hierbij wordt specifiek ingezoomd op een nieuwe methode om de oppervlakkige afvoer van fosfor te kwantificeren door gebruik te maken van perceelskenmerken. Vervolgens wordt in hoofdstuk 4 ter illustratie dieper ingegaan op de effectiviteit van bufferstroken en hoe op basis van generieke en specifieke perceelskenmerken ruimtelijk expliciet in kaart kan worden gebracht waar bufferstroken het effectiefst kunnen worden ingezet om de waterkwaliteit te verbeteren. De studie rondt af met een aantal aanbevelingen en een vooruitblik, waarbij speciale aandacht wordt gegeven aan de aansluiting op het (te ontwikkelen) waterkwaliteitsmodel en handvatten voor de haalbaarheid van KRW-doelen, de ondersteuning van het DAW-spoor en de relatie van deze studie met aanverwante beleidsthema's, waarbij maatwerk rondom het landbouwperceel centraal staat. 


\section{$2 \quad$ Analyse recente studies}

\subsection{Beschouwde studies}

Op basis van expertise bij de auteurs zijn recente studies verzameld die gaan over de belasting van het oppervlaktewater met de nutriënten stikstof $(N)$ en fosfor $(P)$ in Noord-Nederland dan wel het perspectief om via agrarische maatregelen bij te dragen aan het verminderen van deze belasting (Tabel 2.1). Veel van de studies over bodem en oppervlaktewater gaan over het beschrijven of modelleren van de nutriënten stikstof en fosfor vanwege de doelstellingen in de Kaderrichtlijn Water.

Tabel 2.1 Recente studies waarin de uitspoeling van nutriënten naar water en de totale nutriëntenbelasting van regionale oppervlaktewateren zijn gekwantificeerd. De studies die duidelijk verweven zijn omdat ze deels een onderdeel van elkaar zijn, staan bij elkaar.

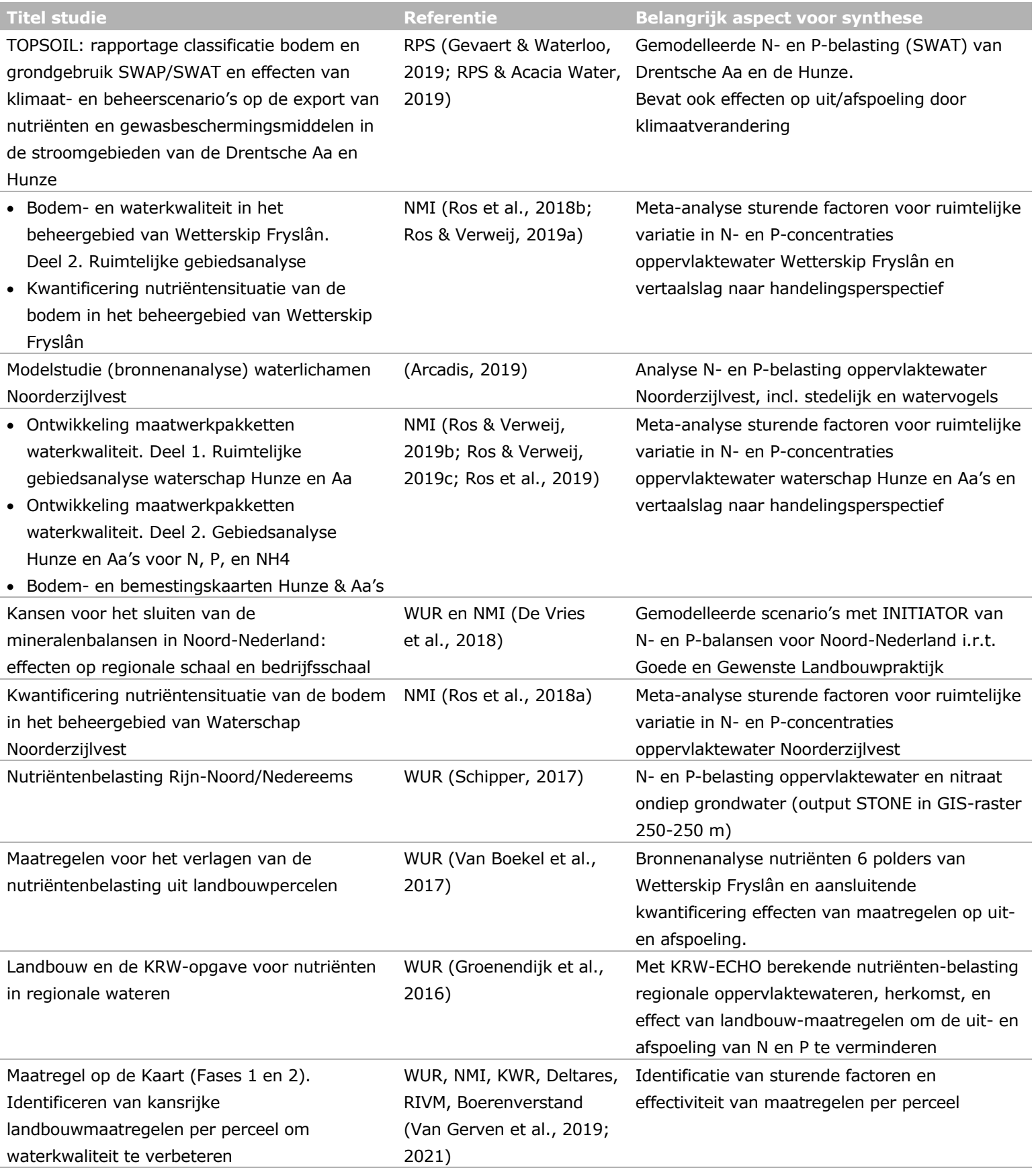


Naast deze studies zijn ook diverse studies uitgevoerd naar de kwaliteit en productiviteit van landbouwbodems en effecten van klimaat(verandering), maar die geen kwantitatieve informatie bieden over de af- en uitspoeling van nutriënten naar water. Deze zijn weergegeven in Tabel 2.2.

Tabel 2.2 Recente studies over bodem, water en klimaat in Noord-Nederland die geen kwantitatieve informatie bieden over de af- en uitspoeling van nutriënten.

\begin{tabular}{|c|c|c|}
\hline Titel studie & Uitgevoerd (referentie) & Belangrijk aspect voor synthese \\
\hline $\begin{array}{l}\text { Inventarisatie provinciale aanpakken voor } \\
\text { klimaat en landbouw }\end{array}$ & WUR (Anonymus, 2019) & $\begin{array}{l}\text { Beknopt overzicht klimaatopgave, beleid, } \\
\text { aanpak per provincie. Alleen informatie in } \\
\text { termen van projecten om uitstoot N/P te } \\
\text { verminderen (Groningen) }\end{array}$ \\
\hline $\begin{array}{l}\text { Verzilting van landbouwgronden in Noord- } \\
\text { Nederland in het perspectief van de effecten } \\
\text { van klimaatsverandering }\end{array}$ & $\begin{array}{l}\text { Acacia (van Staveren \& } \\
\text { Velstra, 2012) }\end{array}$ & Verzilting risicokaart Noord-Nederland \\
\hline $\begin{array}{l}\text { Boeren op weg naar klimaatbestendige } \\
\text { productie }\end{array}$ & LTO Noord (Prins, 2011) & $\begin{array}{l}\text { Overzicht van resultaten uit project Klimaat en } \\
\text { Ruimte }\end{array}$ \\
\hline $\begin{array}{l}\text { Klimaat en landbouw Noord-Nederland: } \\
\text { effecten van extremen. Klimaat en landbouw } \\
\text { Noord-Nederland. Rapportage van fase } 2\end{array}$ & $\begin{array}{l}\text { Grontmij, WUR (De Wit } \\
\text { et al., 2009) (Schaap, } \\
\text { 2009) }\end{array}$ & $\begin{array}{l}\text { Inschatting van de invloed van klimaat op } \\
\text { teelten in jaar } 2040 \text { en } 2100 \text {. Inventarisatie } \\
\text { adaptatiemaatregelen }\end{array}$ \\
\hline
\end{tabular}

\subsection{Analyse van de beschouwde studies}

Binnen de eerdergenoemde gebiedsstudies kunnen drie soorten studies worden onderscheiden:

- Studies die op basis van procesmodellen inzicht geven in de kringloop van stikstof en fosfor en daarmee ook de belasting van het oppervlaktewater kwantificeren. Hierbij wordt gebruikgemaakt van modellen gericht op het gedrag van nutriënten in de bodem zoals STONE, SWAP/SWAT en INITIATOR of het oppervlaktewatersysteem zoals SOBEK of een combinatie van beide (KWR-ECHO).

- Studies die de ruimtelijke en temporele variatie in bodemkwaliteit en bemesting ruimtelijk in kaart brengen en deze relateren aan het risico op $\mathrm{N}$ - en $\mathrm{P}$-verliezen naar het oppervlaktewater dan wel het handelingsperspectief van agrarische maatregelen.

- Studies die op basis van statistische modellen inzicht geven in de relatie tussen gebieds-kenmerken en het voorkomen van (te) hoge $\mathrm{N}$ - en $\mathrm{P}$-concentraties in het oppervlaktewater.

In het navolgende wordt ingegaan op de inzichten die aan deze drie soorten studies kunnen worden ontleend.

\subsubsection{Inzicht op basis van procesmodellen}

De nutriëntenbelasting van het oppervlaktewater is vaak afkomstig van af- en uitspoeling van landbouwbodems, effluenten van rwzi's, inlaat en toestroming van gebiedsvreemd water en atmosferische depositie. Bronnenanalyses geven aan hoeveel stikstof en fosfor in het watersysteem terechtkomt, wat daarvan de bronnen zijn, welke retentie in het oppervlaktewater optreedt en de hoeveelheid die (belasting minus retentie) wordt uitgemalen of afgevoerd. In de huidige praktijk wordt hierbij vooral gebruikgemaakt van procesmodellen, grotendeels gebaseerd op STONE (zie kader). Daarnaast wordt gebruikgemaakt van de Emissieregistratie, om zo extra inzicht te krijgen in de belasting van andere bronnen van nutriënten zoals vogels, erfafspoeling en overstorten. 


\section{STONE-model}

STONE is een simulatiemodel dat bestaat uit meerdere modellen en wordt gebruikt om een beeld te krijgen van de gevolgen van het mestbeleid voor de emissie van stikstof en fosfaat naar het grond- en oppervlaktewater. Het is een consensusmodel dat in samenwerking met RIVM en Rijkswaterstaat (toenmalig onderdeel RIZA) is ontwikkeld voor nationale beleidsevaluaties. STONE berekent ruimtelijke en temporele patronen van de nitraatconcentratie in het grondwater, de fosfaatophoping in de bodem en belasting van het oppervlaktewater met stikstof en fosfor. Verder berekent STONE posten van de N- en Pbalans van de bodem en kan het diverse scenario's in intensiteit van de veestapel en de aanwending van dierlijke mest en kunstmest doorrekenen. Bijlage 1 geeft verdere informatie over STONE (versie 2.4).

Bronnenanalyses geven inzicht in (of kunnen inzicht geven in):

a. De herkomst van stikstof en fosfor, met onderscheid naar bronnen en oorzaken;

b. Afwenteling (van nutriëntenbelasting) op benedenstroomse (rijks)wateren;

c. Effecten van diverse type maatregelen om de nutriëntenbelasting te verminderen.

Figuur 2.1 geeft schematisch weer hoe zo'n bronnenanalyse voor nutriënten wordt uitgevoerd.

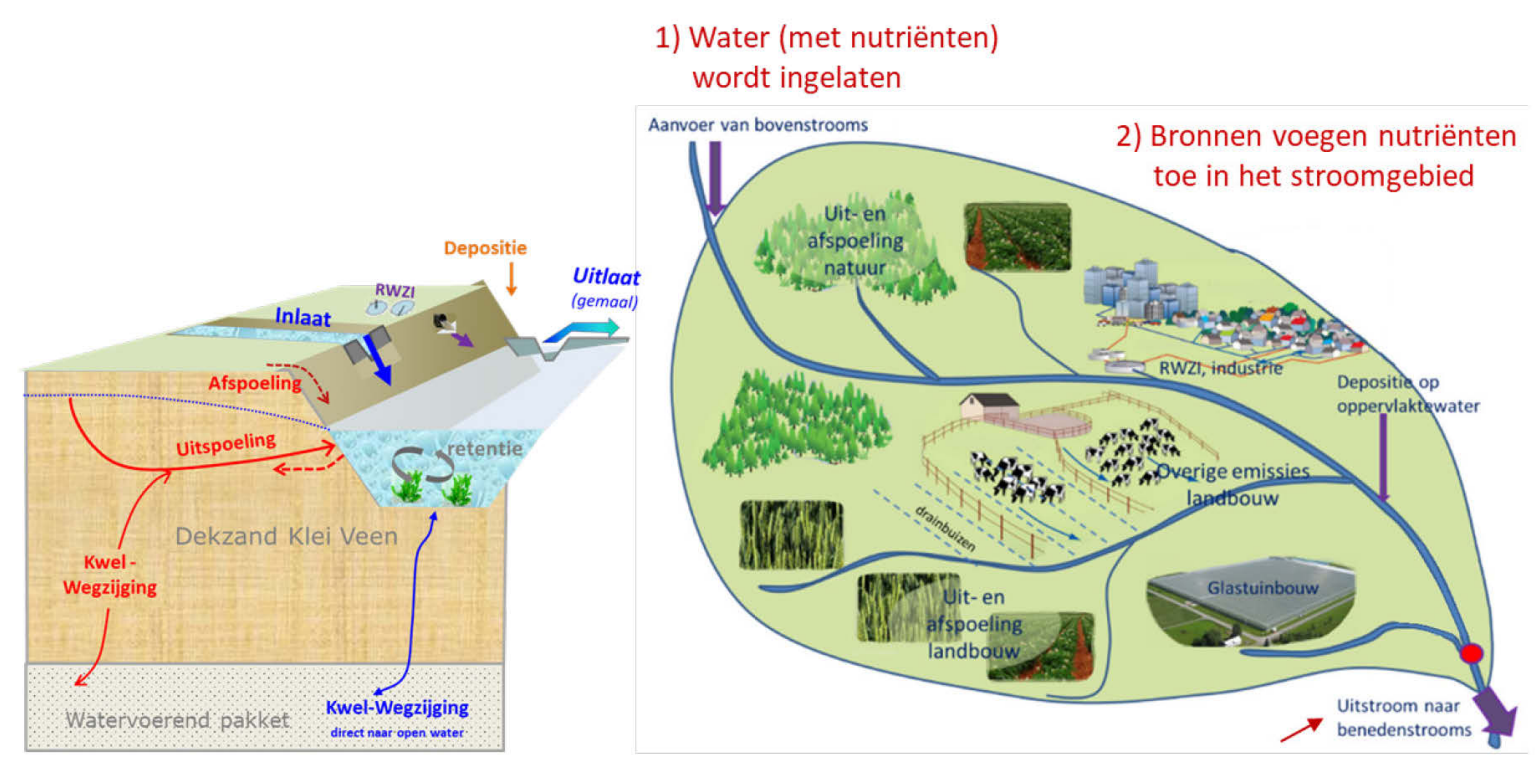

3. Water (met nutriënten) wordt afgevoerd

Figuur 2.1 Schematische weergave bronnenanalyses nutriënten oppervlaktewater. Links de emissieroutes afspoeling, uitspoeling, kwel en wegzijging vanaf landbouw en natuurgronden, waterinlaat, rwzi's, depositie, retentie en de resterende uitlaat. Rechts de aanvoer of inlaat vanuit bovenstroomse gebieden, de bronnen in het stroomgebied en de uitstroom (of uitmaal vanuit polders) naar benedenstroomse wateren.

Afhankelijk van de schematisatie van oppervlaktewatersysteem en/of inzet van aansluitende modules kunnen ook concentraties en effecten op aquatische ecologie worden berekend. Aan de hand van deze analyses kan de haalbaarheid van KRW-doelen worden geëvalueerd en de opgave voor vermindering van de stikstof- en fosforbelasting worden bepaald die ertoe moet leiden dat de ecologische doelen kunnen worden bereikt. Beleidsmatig wordt die reductieopgave verdeeld over de partijen die de nutriënten in het watersysteem brengen, naar rato van hun aandeel in de totale belasting.

In de meeste studies wordt gebruikgemaakt van de rekeneenheden van het model STONE. Hierin vormt de combinatie SWAP-ANIMO de kern om de vocht- en nutriëntenhuishouding in het bodemprofiel dynamisch te simuleren. Belangrijke modelinput is het klimaat (neerslag en verdamping), de mestgiften, de gewasgroei en gewasopbrengsten (landgebruik en gewasrotatie). De mestgiften worden berekend op basis van dieraantallen, excretiefactoren, stalemissies, mesttransporten, mestverwerking en de gebruiksnormen. Bijlage $1 \mathrm{geeft}$ een overzicht van de opzet 
van STONE. De ruimtelijke verspreiding van mest wordt via een separate mestverdelingsmodule in kaart gebracht, waarbij dat tot 2020 gebeurde met de module MAMBO en vanaf 2020 met de module INITIATOR. Het model INITIATOR wordt daarnaast ook separaat gebruikt om het gedrag van koolstof, stikstof, fosfor, metalen en andere nutriënten te kwantificeren en kan wat betreft de $\mathrm{N}$ - en P-emissie naar het grond- en oppervlaktewater gezien worden als een empirische modelversimpeling van STONE. De berekende uit- en afspoeling naar het oppervlaktewater van deze modellen is niet accuraat om op perceelniveau uitspraken te doen over het voorkomen van hotspots en hot moments, maar biedt wel gericht onderbouwing van verschillen die samenhangen met de aanwezige perceelskenmerken.

In de landelijke bronnenanalyse "Landbouw en KRW-opgave voor nutriënten" (Groenendijk et al., 2016) zijn met de methode KRW-ECHO de emissies en bronverdeling van stikstof en fosfor naar regionale oppervlaktewateren berekend voor de periode 2010 tot en met 2013. Een belangrijke basis in die methode is de indeling van de regionale wateren in ongeveer 600 deelstroomgebieden (ook wel aangeduid als vanggebieden). Voor ieder vanggebied worden, zoals aangegeven in Figuur 2.1, de punt- en diffuse bronnen, waterinlaat en toestroming van bovenstroomse regionale en rijkswateren gekwantificeerd. Omdat ook de retentie in het regionale oppervlaktewater wordt berekend, kan per deelstroomgebied de uitgaande hoeveelheden stikstof en fosfor in kaart worden gebracht. Om onderscheid te kunnen maken in antropogene en natuurlijke bronnen of oorzaken, worden in de methode de verschillende oorzaken (bronnen) van de af- en uitspoeling uit landbouwbodems onderscheiden, namelijk af- en uitspoeling door actuele mestgiften, historische mestgiften, natuurlijke nalevering bodemcomplex, atmosferische depositie en kwel naar het bodemprofiel in lokaal (eerder) geïnfiltreerd oppervlaktewater. In die studie zijn ook effecten berekend van verschillende maatregelen door het aanpassen van specifieke modelcoëfficiënten die ingrijpen op het gedrag van nutriënten in de bodem. Dit leidde concreet tot een kwantificering van maatregelen gericht op het verhogen van de nutriëntenefficiëntie van meststoffen, op het verbeteren van de bodemstructuur en op het verbeteren van de waterhuishouding via betere drainagesystemen.

Voor het waterschap Noorderzijlvest zijn in de waterkwaliteitsstudie die door Arcadis in 2019 is uitgevoerd de rekenresultaten van STONE aangehouden als input voor het dynamische oppervlaktewaterkwaliteitsmodel SOBEK (Arcadis, 2019). Hierbij is niet gebruikgemaakt van de originele STONE-berekeningen, maar van de gegevens zoals deze verwerkt zijn in jaarlijkse getallen van de Emissieregistratie. Dit zijn jaargemiddelden van de totale uit- en afspoeling. Door Arcadis zijn deze bewerkt tot fluxen per seizoen. Om de totale nutriëntenbalansen te kwantificeren, zijn hier met gebiedsspecifieke kennis de emissies van kwel, overstorten, rwzi's, nalevering uit waterbodem, afstroming van verharde oppervlakken, voer van vissers en watervogels aan toegevoegd. Voor watervogels is gebruikgemaakt van literatuur en vogeltellingen die later ook zijn gebruikt in het kwantificeren van deze bron voor Emissieregistratie.

Voor het beheergebied van Hunze en Aa's is met het project TOPSOIL de waterflux in de bodem $\left(\right.$ SWAP $^{3}$ ) gemodelleerd (Gevaert \& Waterloo, 2019; RPS \& Acacia Water, 2019), inclusief de verblijftijden van stoffen in oppervlaktewateren (gebruikmakend van het model SWAT ${ }^{4}$ ). De bodemkwaliteit in deze studies is gedefinieerd volgens STONE2.1 met diverse aanpassingen (RPS \& Acacia Water, 2019). Naast stikstof en fosfor zijn met SWAT ook zes gewasbeschermingsmiddelen gemodelleerd. Het gebruik van SWAP/SWAT maakt het mogelijk om scenarioberekeningen te doen. In dit project zijn die gedaan voor het jaar 2050 (Gevaert \& Waterloo, 2019). Voor de af- en uitspoeling is gerekend met de stoffenmodule van SWAT. Deze module beschrijft de processen in de bodem minder gedetailleerd dan ANIMO. Voor de interpretatie moet verder worden bedacht dat de mestgiften (tijdstip, type, timing) die in de modelstudie zijn aangehouden sterk afwijken van hetgeen in de modelstudies van STONE en INITIATOR wordt aangehouden en berekend.

Voor zes polders in het beheergebied van Wetterskip Fryslân heeft de WUR met KRW-ECHO de totale belasting en herkomst van de nutriënten berekend voor de periode 2010-2013. Om het landelijke modelinstrumentarium STONE toepasbaar te maken op deze regionale schaal, zijn hieruit

\footnotetext{
3 SWAP (Soil-Water-Air-Plant) simuleert water en stoffen in bodems. https://www.swap.alterra.nl/. Wordt ook gebruikt voor STONE.

4 SWAT (Soil Water Assessment Tool simuleert water en stoffen per stroomgebied https://swat.tamu.edu/
} 
rekeneenheden geselecteerd die in een fijnere regionale schematisering $(25 \times 25 \mathrm{~m})$ goed passen bij de landgebruiks-, bodem- en grondwatertrappenkaart. Met deze rekeneenheden is de af- en uitspoeling opnieuw berekend en daarbij ook de bronnen achter de af- en uitspoeling. Een belangrijke onzekerheid in de studie zijn de hoeveelheden (gebiedsvreemd) water die in de zomer worden ingelaten. In 2020 is een update van deze studie gemaakt, waarbij de belasting is berekend tot en met 2017 en een opsplitsing is gemaakt in de belasting tijdens het winterhalfjaar en zomerhalfjaar. De hoeveelheden inlaatwater zijn aangepast op basis van actuele inzichten van het Wetterskip.

In de studie van de Vries et al. (2018) werkten WUR en NMI samen om voor heel Noord-Nederland de gevolgen in kaart te brengen van veranderingen in mestbeleid en landbouwbeleid op de aan- en afvoer van koolstof en nutriënten. De huidige landbouwpraktijk wordt daarbij vergeleken met een gewenste landbouwpraktijk die nodig is om de doelen voor grond- en oppervlaktewaterkwaliteit te realiseren, evenals de impact van elf beleidsscenario's die betrekking hebben op de mestaanvoer, -verdeling en -samenstelling. Hierbij maakten ze gebruik van het model INITIATOR, uitgaande van de bedrijfsgegevens uit het jaar 2015.

\subsubsection{Inzicht op basis van data en praktijkkennis}

Omdat bodemparameters die de $\mathrm{N}$ - en P-verliezen naar het oppervlaktewater sturen ruimtelijk sterk kunnen variëren, zijn in 2018 en 2019 diverse studies uitgevoerd om de ruimtelijke variatie in bodemeigenschappen, waterkwaliteit en landbouwpraktijk in beeld te brengen. Hierbij wordt gebruikgemaakt van openbare databronnen en van gegevens uit agrarische laboratoria. Per agrarisch perceel wordt op basis van deze informatie in kaart gebracht waar er risico's liggen op het voorkomen van hoge verliezen van $\mathrm{N}$ en $\mathrm{P}$ naar het oppervlaktewater. Een vergelijkbare systematiek is gebruikt op basis van openbare perceelskenmerken in het recentelijk ontwikkelde adviesinstrument 'MaatregelOp-De-Kaart' (MOK, Van Gerven et al., 2019; 2021) en op basis van bodemanalyses uit agrarische laboratoria in het ontwikkelde BedrijfsBodemWaterPlan (BBWP, Ros et al., 2020a).

De MOK geeft op perceelniveau inzicht in de risico's van uit- en afspoeling op basis van bodemtype, landgebruik, de aanwezigheid van drainage (Massop \& Schuiling, 2016), het risico op ondergrondverdichting (Van den Akker et al., 2012), grondwatertrap en een aantal morfologische kenmerken van elk perceel zoals helling, geulen, greppels en afstand tot oppervlaktewater. Gebaseerd op deze risico's wordt vervolgens voor elk perceel inzicht gegeven in de best passende maatregelen met het oog op een betere waterkwaliteit. In de recentste versie (Groenendijk et al., 2021) brengt de MOK ook de KRW-opgave voor het verminderen van de nutriëntenbelasting in beeld zoals die in de studie van Groenendijk et al. (2016) op basis van de landelijke bronnenanalyse is toebedeeld aan landbouw.

De BBWP brengt op basis van de gebiedsopgave en kenmerken van agrarische percelen de aanwezige kansen (en risico's) in beeld in relatie tot het vasthouden en bufferen van water, het verhogen van de efficiëntie van bemesting, het vasthouden van fosfaat (voorkomen afspoeling) en stikstof en nitraat (voorkomen uitspoeling en afspoeling). Het risico op P-afspoeling wordt daarbij gekwantificeerd op basis van rekenregels voor het risico op oppervlakkige afspoeling (Hattum, 2011), de natte omtrek en helling van het perceel (Van Gerven et al., 2019), de grondwatertrap, de P-retentie via Al-ox en Fe-ox (bodemdata bovengrond), de direct beschikbare hoeveelheid fosfaat, $\mathrm{P}-\mathrm{CaCl}_{2}$ (bodemdata), de $\mathrm{P}$ verzadigingsgraad (bodemdata) en het risico op ondergrondverdichting (Van den Akker, 2012). Het risico op afspoeling en ondiepe uitspoeling van stikstof naar het oppervlaktewater is gebaseerd op rekenregels voor het risico op oppervlakkige afspoeling (Hattum, 2011), de natte omtrek en helling van het perceel (Van Gerven et al., 2019), de grondwatertrap (bodemkaart), de hoeveelheid stikstof in de bouwvoor alsook de afbreekbaarheid ervan, waarbij rekening wordt gehouden met landgebruik (bodemdata) en het risico op ondergrondverdichting (Van den Akker, 2012).

Voor heel Noord-Nederland zijn de volgende bodemgegevens op perceelniveau beschikbaar.

- De hoeveelheid fosfaat $(P)$ in de bodem, in het bijzonder voor die bepalingen die van invloed zijn op de bemestingsruimte op agrarische bedrijven. Voor bouwland is dat het Pw-getal (fosfaatextractie met water, $\mathrm{mg} \mathrm{P}_{2} \mathrm{O}_{5} \mathrm{l}^{-1}$ ) en voor grasland de hoeveelheid PAL (fosfaatextractie met ammonium- 
lactaat, $\mathrm{mg} \mathrm{P}_{2} \mathrm{O}_{5} 100 \mathrm{~g}^{-1}$ ). Daarnaast wordt ook standaard de hoeveelheid plant-beschikbaar fosfaat gemeten via een extractie met $0,01 \mathrm{M} \mathrm{CaCl}_{2}$.

- De hoeveelheid organische stof (\%) en organische stikstof in de bodem ( $\mathrm{mg} \mathrm{N} \mathrm{kg}^{-1}$ ) en de afbreekbaarheid ervan zoals dat gemeten wordt via een anaerobe incubatiemethode ( $\mathrm{N}$ mineralisatiesnelheid, $\mathrm{mg} \mathrm{N} \mathrm{kg}^{-1}$ ).

- Het landgebruik, bodemtype, drainage en grondwatertrap, omdat deze in sterke mate de transportroutes en het gedrag van fosfaat in de bodem beïnvloeden, en basisbodemkenmerken als kleigehalte en $\mathrm{pH}$.

- De P-verzadiging (\%) en het P-retentievermogen van de bodem, dat wil zeggen de mate waarin een grond is 'opgeladen' met fosfaat en risico's oplevert voor hoge P-verliezen richting het oppervlaktewater.

- Morfologische kenmerken van agrarische percelen in relatie tot het risico op afspoeling en ondiepe uitspoeling (zie o.a. Van Gerven et al., 2020; Ros et al., 2020a).

Voor de ontwikkeling van de bodemkaarten met ruimtelijke variatie in fosfor en stikstof wordt gebruikgemaakt van bodemanalyses die door agrariërs zijn uitgevoerd in het kader van hun bodembeheer en bemestingspraktijk. De gebruikte bodemgegevens zijn daarbij aangeleverd door het agrarisch laboratorium Eurofins Agro (voorheen BLGG AgroXpertus). Van elk perceel wordt namelijk frequent (minimaal één keer per vier jaar) een heel scala aan fysische, biologische en chemische parameters gemeten. Omdat de resultaten niet herleidbaar mogen zijn tot individuele percelen (de brondata zijn namelijk eigendom van boeren), is een (geo)statistische methode toegepast om voor elk perceel een waarde te geven op basis van de eigenschappen van naburige percelen en locatiespecifieke kenmerken als het landgebruik, satellietgegevens, het bodemtype, de eigendomssituatie, de grondwatertrap en een set aan landschappelijke en bodemkundige covariabelen.

Naast inzicht in de bodemkwaliteit is er in deze studies veel aandacht voor de landbouwkundige praktijk van bodembeheer en bemesting. Ook deze is voor zover mogelijk in kaart gebracht op perceelniveau, daarbij gebruikmakend van het mestverdelingsinstrumentarium INITIATOR. Dit gebeurt zowel in relatie tot de huidige als de landbouwkundig gewenste praktijk. Deze methode is ontwikkeld door het Nutriënten Management Instituut (NMI), in samenwerking met Wageningen Environmental Research (WEnR). Voor de mineralenbalans wordt de aanvoer van stikstof, fosfaat, kalium, zwavel, calcium, magnesium en organische stof op bedrijfsniveau vergeleken met de gewenste agronomische behoefte aan nutriënten en de behoefte om het organischestofgehalte op peil te houden. De adviezen hiervoor zijn afkomstig uit de adviesbasis voor de bemesting van akkerbouw- en vollegrondsgroentegewassen (Praktijkonderzoek Plant \& Omgeving, 2018) en de adviesbasis bemesting van de Commissie Bemesting Grasland en Voedergewassen (Commissie Bemesting Grasland en Voedergewassen, 2017). Een gedetailleerde beschrijving van de methode wordt gegeven in De Vries et al. (2018). Omdat dit op perceel- en bedrijfsniveau bekend is, biedt dit heel gericht inzicht in de mogelijkheden die er zijn om via een Goede Landbouwpraktijk te sturen op een bemestingspraktijk waarmee onnodige verliezen naar het oppervlaktewater kunnen worden voorkomen.

\subsubsection{Inzicht op basis van statistische modellen}

Wetterskip Fryslân heeft in 2018 samen met het Mesdagfonds een onderzoek opgezet om consensus te krijgen over het belang van bronnen en routes van stikstof- en fosforverliezen naar het watersysteem en over mogelijke oplossingsrichtingen om de kwaliteit van het oppervlaktewater in het beheergebied te verbeteren (Ros et al., 2018b). De kern van dit onderzoek ligt op kwantitatieve onderbouwing van diverse bronnen (zoals rwzi's, watervogels, bodem en bemesting) en emissieroutes op basis van beschikbare metingen bij het waterschap, gegevens uit agrarische meetnetten én praktijkexpertise uit de agrarische sector. Op basis van dit inzicht kunnen gebiedsgerichte maatwerkoplossingen worden ontwikkeld om de verliezen van stikstof en fosfor naar het oppervlaktewater te verlagen. Vergelijkbare onderzoeken zijn uitgevoerd voor het beheergebied van waterschap Hunze en Aa's en Noorderzijlvest.

Deze studies van het NMI (Ros et al., 2018b; Ros \& Verweij, 2019a) maken gebruik van een verklarende statistische techniek: er wordt via machine learning technieken gezocht naar de meest 
verklarende factoren voor de gemeten concentraties in het zomerhalfjaar van stikstof en fosfor in de regionale oppervlaktewateren. Hierbij wordt gebruikgemaakt van Gradient Boosted Trees, een ensemble-methode die zoekt naar patronen in meetgegevens en op basis van meerdere beslisbomen (decision trees) een voorspelling geeft van de ruimtelijke en temporele variatie in nutriëntenconcentraties van het oppervlaktewater. Bij Gradient Boosted Trees worden meerdere bomen achter elkaar getraind, waarbij het model gedurende de training zelf leert welke gebiedskenmerken daadwerkelijk relevant zijn en gebruikt kunnen worden om de ruimtelijke variatie in de nutriëntenconcentraties in het oppervlaktewater te verklaren. Hiervoor wordt gebruikgemaakt van willekeurige selecties uit de verzamelde meetgegevens en 'leert' het model van elke voorgaande analyse. De kracht van deze aanpak (machine learning) is dat het op de achtergrond slim gebruikmaakt van honderden beslisbomen; in combinatie met elkaar kan zo een betere voorspelling worden gegeven dan het gebruik van één gefinetuned lineair regressiemodel. Om te weten te komen of het model de juiste patronen vindt, is het van belang het model te valideren. Machine learningmodellen zoals Gradient Boosted Trees zijn namelijk erg flexibel en kunnen met de verkeerde configuratie zorgen voor een overfitting, waardoor het model heel goed in staat is om individuele peilgebieden en maanden te herkennen, maar slecht in staat is om inzicht te geven in de onderliggende generieke verbanden. Juist deze verbanden zijn zinvol, omdat die inzicht kunnen geven in sturende factoren voor de waterkwaliteit. Om dit probleem te voorkomen, worden de modellen gevalideerd op een onafhankelijke dataset.

Aangezien machine learning-modellen zogenoemde black boxes zijn, kan er niet eenvoudig "in het model" gekeken worden wat er precies gebeurt. Daarom zijn er verschillende methodes ontwikkeld om deze modellen te interpreteren. Dit kan op twee niveaus: globaal en lokaal. Een globale interpretatie brengt in beeld welke metingen of factoren relevant zijn om over het hele beheersgebied de variatie in $\mathrm{N}$ - en $\mathrm{P}$-concentraties in het oppervlaktewater te verklaren. Hierbij kan per factor aanvullend in beeld gebracht worden hoe de $\mathrm{N}$ - en P-concentratie afhangt van de meegenomen gebiedskenmerken. In elk peilgebied of afwateringseenheid kunnen echter bijzondere omstandigheden voorkomen waarbij één of meerdere factoren een heel grote invloed hebben op de nutriëntenconcentraties. Denk bijvoorbeeld aan een rioolwaterzuiveringsinstallatie of lokale ijzerrijke kwel die de concentraties in één peilgebied kunnen beïnvloeden. Om dit te analyseren, kan per peilgebied inzicht worden gegeven in de meest sturende factoren voor de nutriëntenconcentraties door gebruik te maken van zogenoemde "Shapleywaarden". Deze waarden laten zien welke variabelen het meeste effect hebben op de voorspelde concentratie ten opzichte van de gemiddelde voorspelling voor alle andere peilgebieden. Voor een uitgebreide onderbouwing van deze analyse verwijzen we graag naar de publicatie Interpretable Machine Learning van Molnar (2018).

Deze statistische modellen zijn sterk afhankelijk van de gebruikte meetgegevens. In de studies die zijn uitgevoerd in Noord-Nederland wordt gebruikgemaakt van openbare data en statistisch bewerkte meetgegevens uit agrarische laboratoria. Omdat ook resultaten van modellen als STONE en INITIATOR bekend waren, zijn deze meegenomen in de ontwikkeling van de statistische modellen. Voor het hele beheergebied van de drie noordelijke waterschappen bleek dat een meta-model gevoed met perceelskenmerken in staat was om de ruimtelijke variatie in de zomergemiddelde $\mathrm{N}$ - en $\mathrm{P}$ concentraties in het oppervlaktewater te voorspellen. Het gebruik van covariabelen uit de mechanistische modellen had weinig meerwaarde voor het in kaart brengen van de ruimtelijke variatie in de concentraties van $\mathrm{N}$ en P. Dat betekent dat statistische modellen hiermee in staat waren om de complexe relaties tussen input, output en perceelskenmerken in de mechanische modellen te benaderen via zogenoemde input-output-relaties. Deze statistische studies geven daarmee een ruimtelijk gedetailleerd beeld van hotspots van de af- en uitspoeling. Extrapolatie naar toekomstige situaties is altijd een zorgpunt. De studies leveren voor de af- en uitspoeling geen andere mechanistische inzichten dan STONE. 


\subsection{Uit- en afspoeling studiegebied}

\subsubsection{Inzicht op basis van procesmodellen}

In een nationale analyse van de nutriëntenbelasting en -herkomst in regionale wateren over de periode 2010-2013 (Groenendijk et al., 2016) blijkt dat de uit- en afspoeling van N en P voor gemiddeld 54 tot $56 \%$ afkomstig is vanuit de landbouwbodem (Figuur 2.2). De belangrijkste bron van stikstof is de uitgevoerde bemesting, terwijl de belangrijkste emissie van fosfor afkomstig is uit de nalevering van de bodemvoorraad. De verschillen tussen de regio's in Nederland zijn daarbij echter groot.
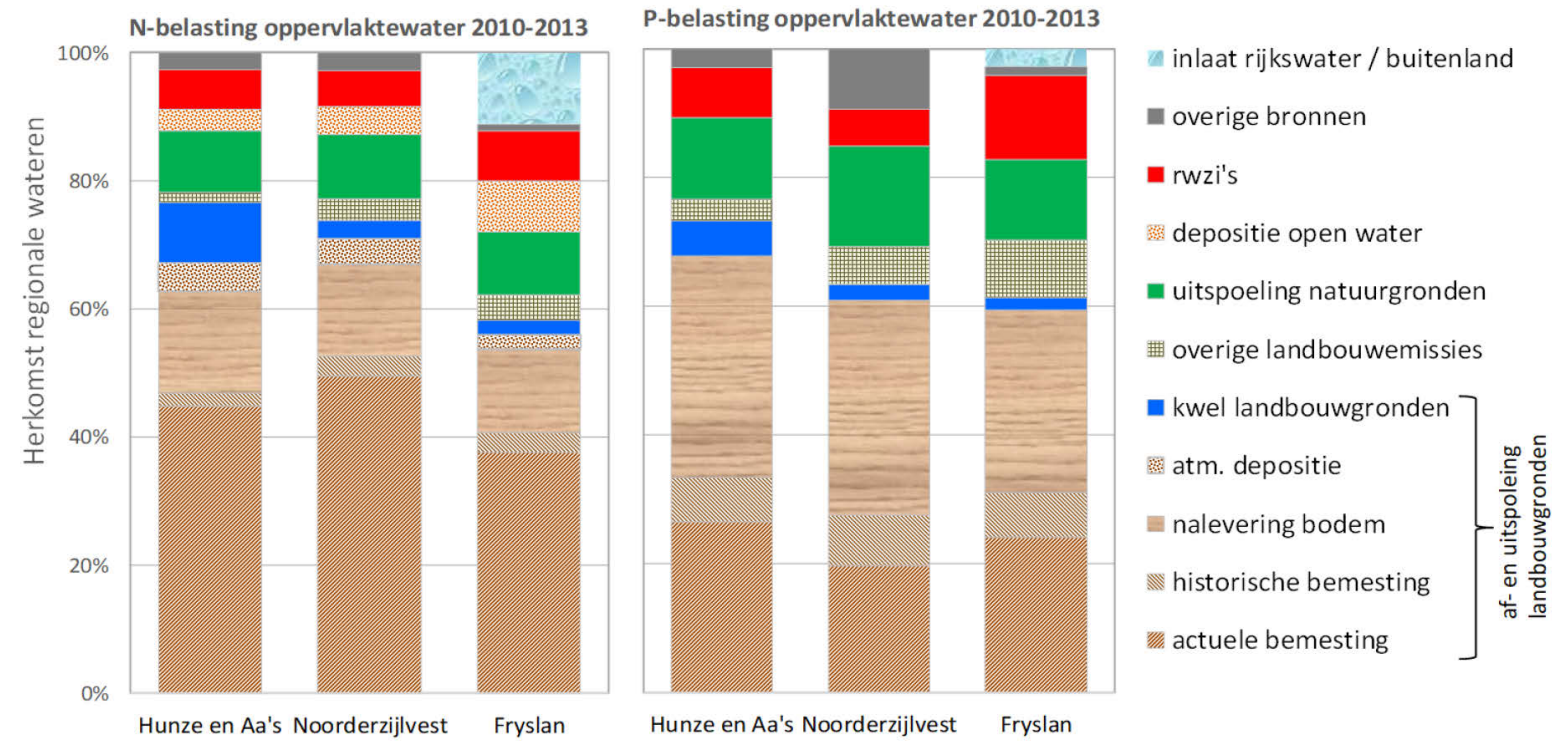

Figuur 2.2 Jaargemiddelde herkomst van stikstof (links) en fosfor (rechts) in regionale wateren over de periode 2010-2013 (bron: Groenendijk et al., 2016).

Het in deze studie berekende aandeel van de uit- en afspoeling is voor stikstof 59\% (Fryslân), 74\% (Noorderzijlvest) en 77\% (Hunze en Aa's); voor fosfor is dit 62\% (Fryslân), 64\% (Noorderzijlvest) en $73 \%$ (Hunze en Aa's). De uit- en afspoeling van stikstof wordt voor ongeveer twee derde bepaald door actuele mestgiften, de uitspoeling van fosfor wordt voor ongeveer de helft bepaald door nalevering.

In de studie van Groenendijk et al. (2016) is op basis van de jaargemiddelde gemeten concentraties in de periode 2010-2013, de gestelde KRW-doelen en de nutriëntenbalansen over die periode, berekend hoeveel de nutriëntenbelasting moet afnemen om te voldoen aan de gestelde KWR-doelen. Hierbij wordt de opgave (vermindering van de nutriëntenbelasting) als volgt berekend:

$$
\text { Opgave }(\text { vracht })=\frac{\text { zomerhalfjaargemiddelde }-K R W_{\text {doel }}}{\text { zomerhalfjaargemiddelde }} \times \text { stofbelasting }(\text { vracht })
$$

Deze opgave wordt vervolgens op basis van de herkomst verdeeld over de sectoren die nutriënten toevoegen aan het oppervlaktewatersysteem. In de landelijke studie (Groenendijk et al., 2016) zijn voor het toedelen vier beleidsvarianten doorgerekend, die onderling verschillen in het wel/niet verdisconteren van de bijdrage van historische mestgiften, kwel, depositie en (semi)natuurlijke nalevering.

Tabel 2.3 geeft de benodigde reductie (opgave) van de voor 2027 voorspelde uit- en afspoeling van stikstof en fosfor uit landbouwpercelen zoals deze in de studie van Groenendijk et al. (2016) is berekend. Bij de interpretatie hiervan moet worden bedacht dat deze opgave is berekend op basis van de gemeten zomerhalfjaargemiddelde concentraties in de periode 2010-2013 en de in 2015 
vastgestelde KRW-doelen voor N en P. In de recentste KRW-analyse (Afstemmingsnota Rijn-Noord 2020) komt naar voren dat het merendeel van de waterlichamen voor stikstof in een goede toestand verkeert (Fryslân 58\%, Hunze en Aa's 81\%, Noorderzijlvest 93\%). Voor fosfor zijn die percentages lager (Noorderzijlvest 33\%, Fryslân 56\% en Hunze en Aa's 88\%). Waar die toestand niet als goed is beoordeeld, ligt er een KRW-opgave om de belasting te verminderen, waarbij uitgegaan kan worden van bovengenoemde formule.

Tabel 2.3 Benodigde reductie van de voor 2027 voorspelde uit- en afspoeling van stikstof en fosfor uit landbouwpercelen om de KRW-opgave te realiseren zoals berekend in de studie van Groenendijk et al. (2016).

\begin{tabular}{lll} 
Beheergebied & $\begin{array}{l}\text { Benodigde reductie stikstof } \\
(\mathrm{kgN} / \mathrm{ha} / \mathrm{j})\end{array}$ & $\begin{array}{l}\text { Benodigde reductie fosfor } \\
(\mathrm{kgP} / \mathrm{ha} / \mathrm{j})\end{array}$ \\
\hline Hunze en Aa's & - & 0 à 0.01 \\
\hline Noorderzijlvest & 0.5 à 0.9 & 0.5 à 1.3 \\
\hline Fryslân & 1.5 à 2.4 & 0.1 à 0.2 \\
\hline
\end{tabular}

Uit die studie komt dus naar voren dat de uit- en afspoeling van stikstof vooral in het beheergebied van Wetterskip Fryslân fors moet afnemen en de uit- en afspoeling van fosfor vooral in het beheergebied van Noorderzijlvest. Door een combinatie van maatregelen (bouwplan, bodembeheer en bemesting) lijkt in de zandgebieden een groot deel van de berekende opgave voor stikstof gerealiseerd te kunnen worden. Voor klei- en veengronden is deze bijdrage kleiner in verband met hoge denitrificatieverliezen (de effectiviteit van een maatregel gericht op stikstofoverschotten is daardoor kleiner). De opgave voor het reduceren van de uit- en afspoeling voor fosfor kan slechts voor een beperkt deel worden gerealiseerd. In aanvulling op maatregelen als bemesting en bodembeheer zijn hier extra maatregelen nodig die ingrijpen op transportroutes en/of maatregelen met een zuiverende werking in het oppervlaktewater.

Vergelijkbare conclusies worden getrokken door Van Boekel et al. (2017), die voor verschillende hydrologische situaties (nat, matig droog, droog) in zes polders in het beheergebied van Wetterskip Fryslân berekeningen hebben uitgevoerd over de effectiviteit van maatregelpakketten. Naast inlaatwater is een groot deel (vaak meer dan 50\%) van de totale $\mathrm{N}$ - en P-belasting afkomstig uit de landbouwbodem. Voor stikstof speelt de actuele bemesting daarin een sleutelrol en ook voor fosfaat is 'actuele' bemesting de grootste bron. Maatregelen die de benutting van nutriënten verhogen, zorgen voor een afname in de $\mathrm{N}$-belasting van $2-20 \%$ op zand- en veengronden, terwijl het effect op kleigrond kleiner was dan $2 \%$. Maatregelen die de bodemkwaliteit verbeteren, verlagen de $\mathrm{N}$-vracht met gemiddeld $30 \%$. Voor het verlagen van de fosforvracht naar het oppervlaktewater is de maatregel akkerranden-beheer effectief. Voor een onbemeste akkerrand ter grootte van $5 \%$ van het perceeloppervlak is een vermindering van de uit- en afspoeling van fosfor berekend, variërend van 0 tot $10 \%$. Voor zandgronden blijkt dat bodemverbetering effectief is om de uit- en afspoeling van fosfor te verminderen; voor kleigronden is dat niet het geval.

De analyse van De Vries et al. (2018) voor Noord-Nederland laat zien dat, uitgaande van de huidige landbouwproductie, het $\mathrm{N}$-overschot op de bodem te hoog is in de zeekleigebieden van Wetterskip Fryslân en Noorderzijlvest en in grote delen van waterschap Hunze en Aa's. Voor fosfor is dat voor alle gebieden te hoog. Ook wanneer er gekeken wordt naar de landbouwkundige behoefte zien we dat op veel akkerbouwbedrijven de huidige P-aanvoer groter is dan dat er landbouwkundig gewenst zou zijn. Op melkveehouderijbedrijven is de P-aanvoer gelijk aan de gewenste praktijk. Om de doelen voor grondwater- en oppervlaktewaterkwaliteit te halen, moeten de huidige bodemoverschotten substantieel worden verlaagd. De berekende omvang van die opgaves zijn in afnemende volgorde: zandgronden, klei, zware klein en veen. Deze studie laat wel zien dat de relatie tussen bemesting en uit- en afspoeling samenhangt met de verwachte gewasproductie op langere termijn en dat er bij stijgende gewasopbrengsten zelfs een situatie kan ontstaan dat de huidige P-aanvoer beperkend is voor een landbouwkundig gewenste situatie. De ruimtelijke variatie in de berekende af- en uitspoeling naar het oppervlaktewater (Figuur 2.3) vertoont in grote lijnen een vergelijkbaar patroon als de resultaten van STONE (Figuur 2.4). Dit geldt ook voor de berekende niveaus (het kleurenverschil 
tussen de figuren komt vooral door de gehanteerde legendaeenheden). De P-verliezen naar het oppervlaktewater zijn hoger in klei dan in veen en zandbodems, en zijn het hoogst in granen en groentegewassen en het laagst bij de teelt van bomen, gras en natuur.

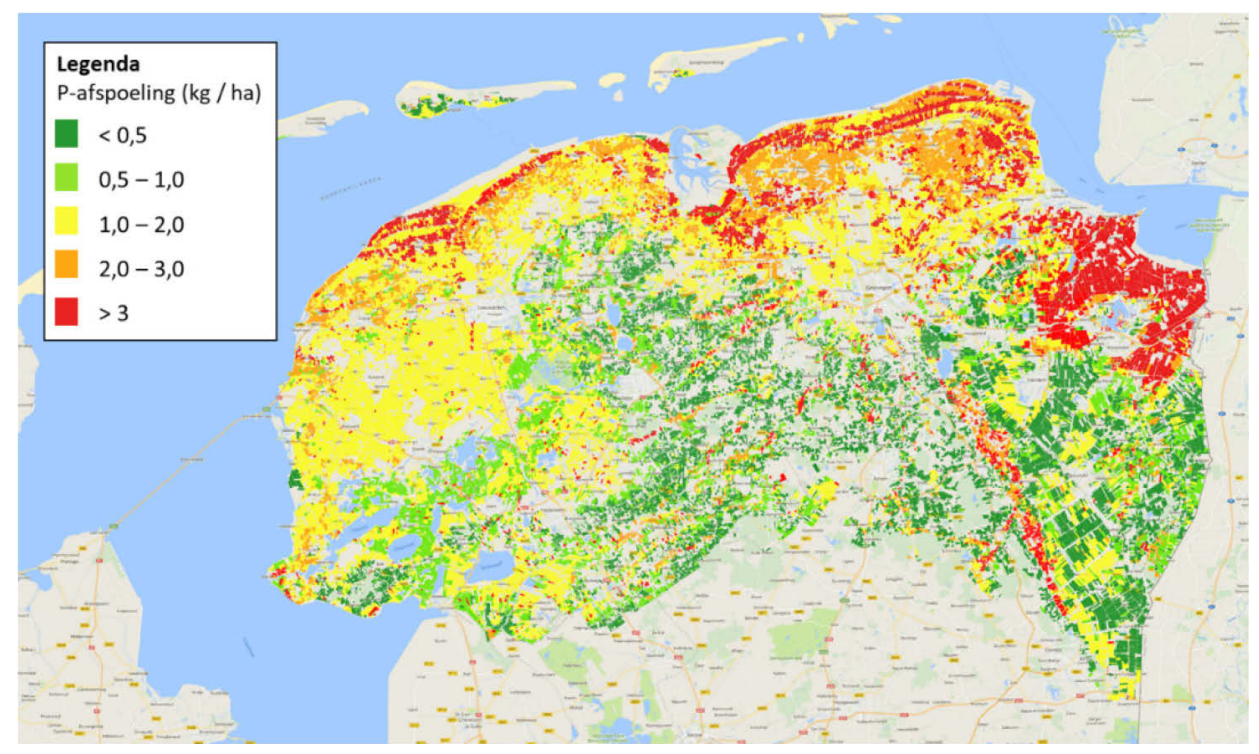

Figuur 2.3 Berekende P-afspoeling en ondiepe uitspoeling naar het oppervlaktewater in 2015, weergegeven in oorspronkelijke gerapporteerde schaal (De Vries et al., 2018).

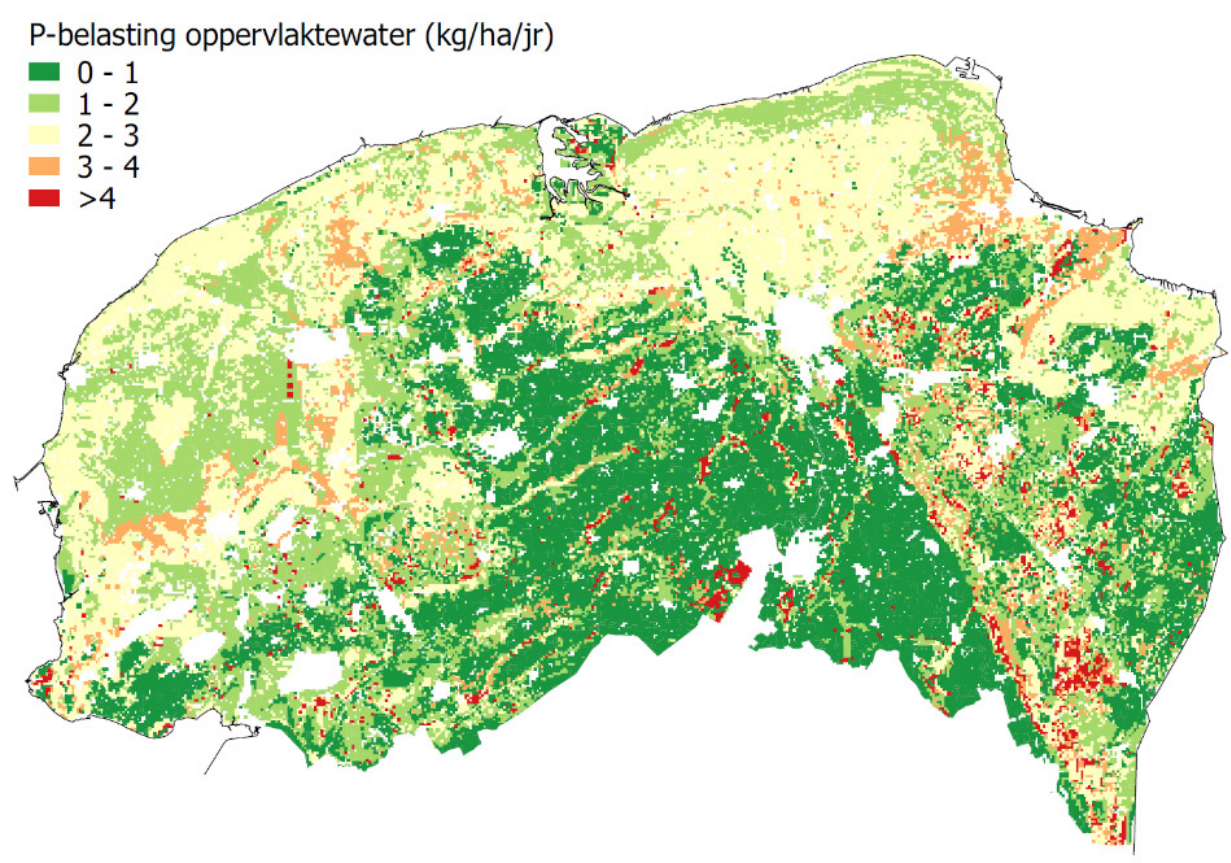

Figuur 2.4 P-uit- en afspoeling naar het oppervlaktewater 2010-2013 berekend met STONE (Schipper, 2017).

De uitgevoerde modelstudie met SWAP-SWAT voor de Drentsche Aa laat een grote ruimtelijke spreiding zien in de berekende P-belasting vanuit de bodem naar het oppervlaktewater, deze varieert van 0,01 tot $0,4 \mathrm{~kg} \mathrm{P} \mathrm{ha}^{-1}$ jaar $^{-1}$. Deze inschatting komt redelijk overeen met de inschattingen van het STONE-instrumentarium. De belangrijkste routes voor een snelle afvoer van N en P zijn oppervlakkige afstroming en afvoer via drainagebuizen. Een verhoogd risico op oppervlakkige afstroming komt het meest voor in beekdalen en gebieden waar de doorlatendheid van de bovenste bodemlaag slecht is (vooral klei, veen en keileem). Afvoer door drainagebuizen komt relatief veel voor waar het berekende grondwater ondiep is. 
Voor de KRW-wateren in Noorderzijlvest is door Arcadis in 2019 een waterkwaliteitsmodel opgesteld dat op basis van eerdere STONE-resultaten een indicatie geeft van de mogelijke $\mathrm{N}$ - en P-verliezen naar het oppervlaktewater en deze verder verfijnt met extra databronnen en lokale expertkennis. Door de sterke koppeling aan STONE-resultaten levert dit model geen nieuwe inzichten op voor de verliezen van $\mathrm{N}$ en $\mathrm{P}$ vanuit de landbouwbodem. De extra belasting op het oppervlaktewater van externe bronnen kan lokaal tot nieuwe inzichten leiden over de impact van agrarische maatregelen, maar een gebiedsbrede inventarisatie van dit model is (nog) niet bekend.

\subsubsection{Inzicht op basis van data en praktijkkennis}

In 2018 en 2019 zijn diverse studies uitgevoerd waarbij op perceelniveau inzicht wordt gegeven in de landbouwkundige bodemkwaliteit en de locatie van mogelijke hotspots voor stikstof- en fosforverliezen naar het oppervlaktewater. Allereerst betreft dat variatie in basisbodemkenmerken, zoals deze ook sturend zijn in de definitie van de rekenplots van ANIMO-SWAP en STONE. Hierbij gaat het concreet om het landgebruik, bodemtype, grondwatertrap, fosfaatbeschikbaarheid en het voorkomen van kwel (Figuur 2.5). Voor combinaties van deze eigenschappen kan met de STONE-modellen aangegeven worden waar de grootste risico's optreden voor verliezen van $\mathrm{N}$ en $\mathrm{P}$ naar het oppervlaktewater.
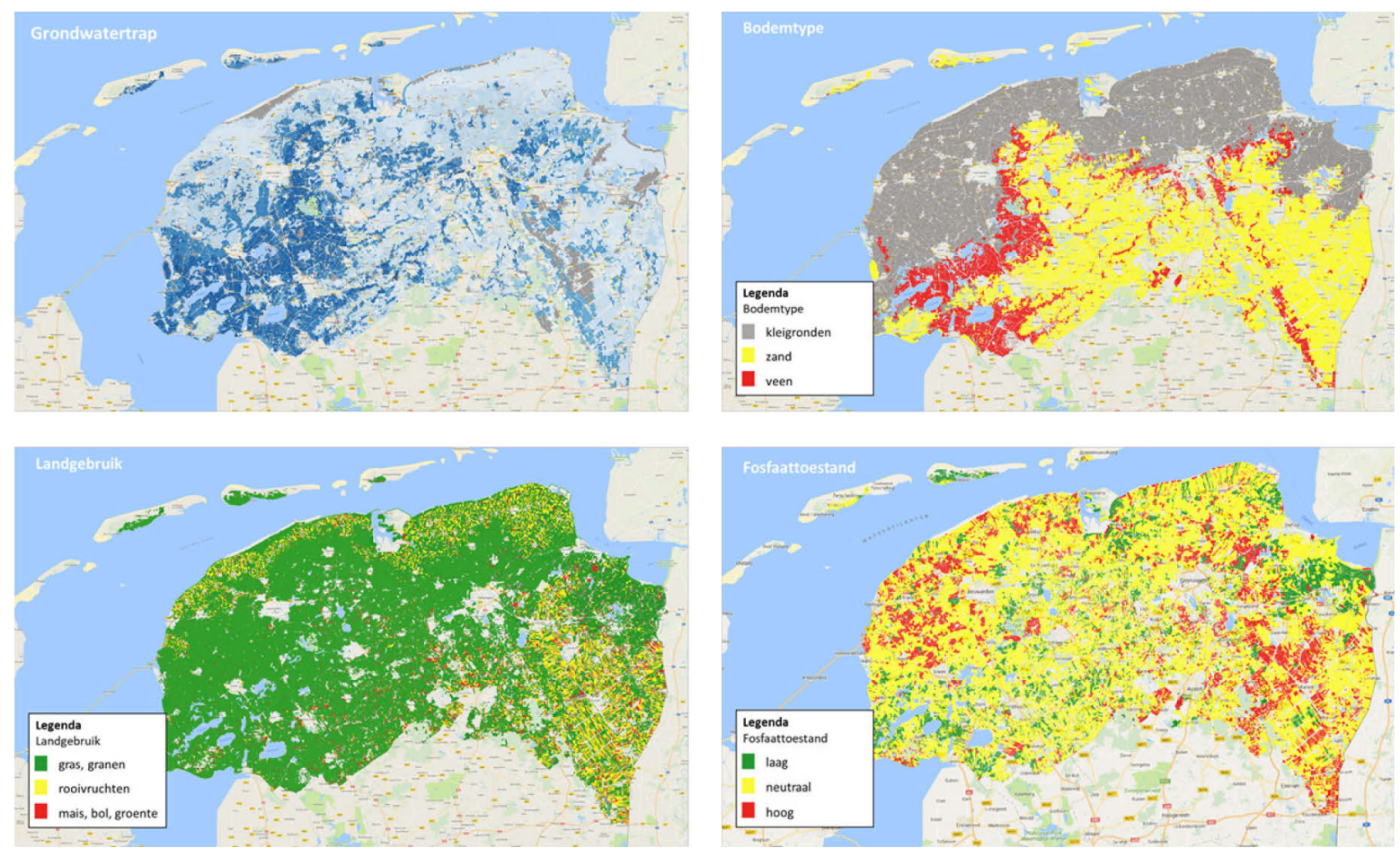

Figuur 2.5 Basis perceelskenmerken die sturend zijn op het voorkomen van $\mathrm{N}$ - en P-verliezen naar het oppervlaktewater: grondwatertrap, bodemtype, landgebruik en fosfaattoestand.

In welke mate er daadwerkelijk sprake is van een verhoogd risico op P-verliezen kan op basis van de morfologie van percelen en gegevens van de $\mathrm{N}$ - en P-voorraden en beschikbaarheid in de bodem ruimtelijk in kaart worden gebracht. Dit gebeurt bijvoorbeeld al op basis van generieke perceelskenmerken in de Maatregel-Op-De-Kaart (Van Gerven et al., 2019; Groenendijk et al., 2021) en op basis van generieke en perceel-specifieke kenmerken in het BedrijfsBodemWaterPlan (Ros et al., 2020a). Als er bijvoorbeeld veel fosfaat in de bodemoplossing aanwezig is (wat vaak de praktijk is bij percelen met een hoge P-toestand), bestaat er een groot risico op P-verliezen. Of het aanwezige fosfaat ook daadwerkelijk uitspoelt, hangt af van de buffercapaciteit van en de mogelijke retentie in de bodem. Vaak wordt hiervoor gebruikgemaakt van de zogenoemde P-verzadigingsgraad (Figuur 2.6): het deel van de fosfaatvastleggingscapaciteit (geschat via de hoeveelheid aluminium- en ijzeroxiden in de bodem) dat 'bezet' is met fosfaat. Bij percelen met een hoge verzadigingsgraad is het risico op uiten afspoeling van fosfaat groter. De P-verzadigingsgraad zoals gebruikt in STONE-rekenplots zijn gemiddeld hoger voor de toplaag dan voor de diepere lagen. De situatie is problematischer op 
bouwland dan op grasland. Buiten landgebruik speelt ook de grondsoort een grote rol. Op klei is de Pverzadigingsgraad het hoogst, gevolg door zand en veen. Actuele gegevens vanuit agrarische laboratoria bevestigen dit beeld, al ligt de gemeten P-verzadigingsgraad in de praktijkpercelen hoger dan gebruikt in de STONE-berekeningen.

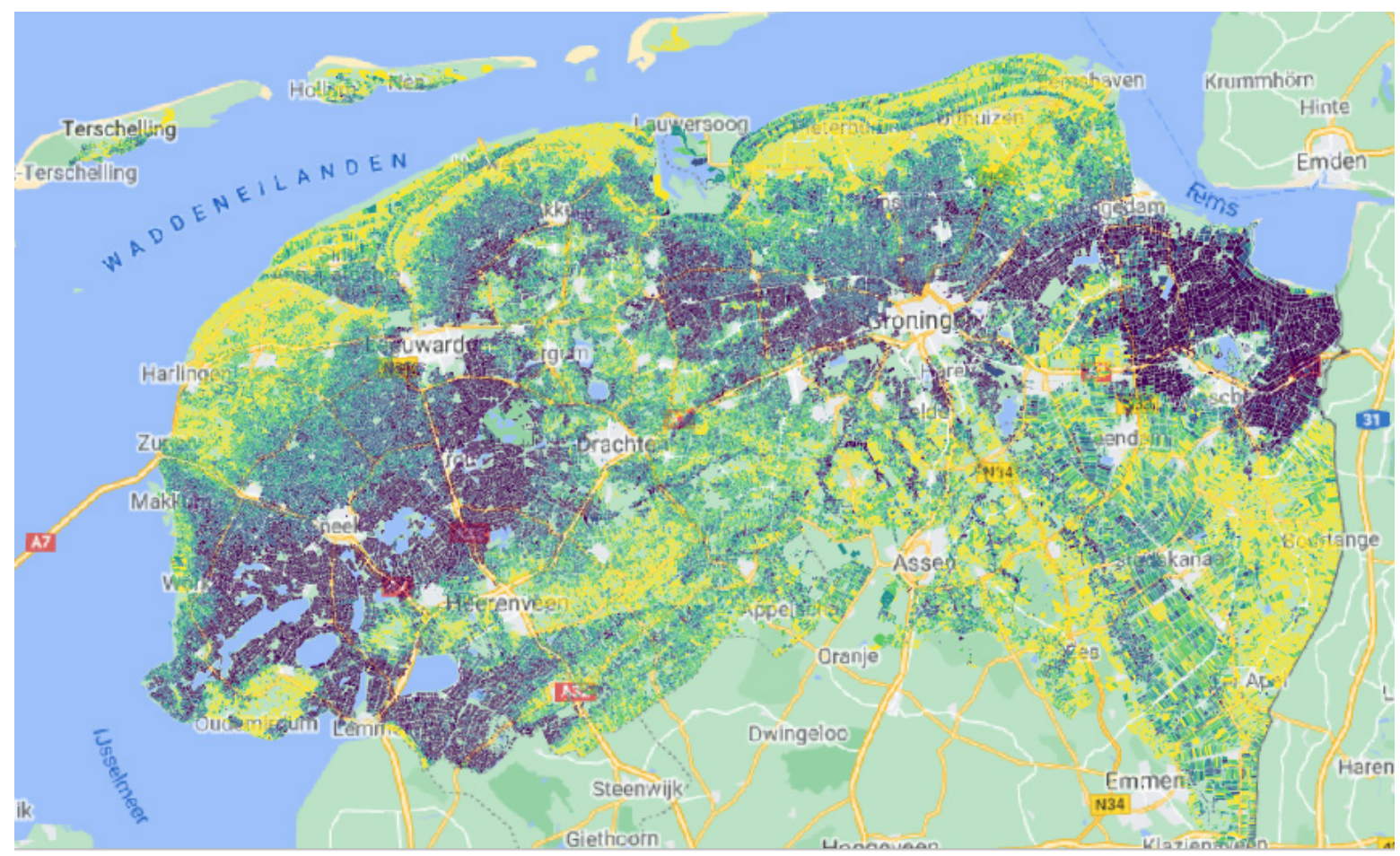

Figuur 2.6 Ruimtelijke variatie in P-verzadigingsgraad in de bovengrond van agrarische percelen, variërend van laag (<30\%, blauw) tot hoog ( $>45 \%$, geel).

De hoeveelheid $\mathrm{N}$-totaal in de bodem is gekoppeld aan het organischestofgehalte. Dit is hoger op de zware kleigronden en gronden met ondiep grondwater die al geruime tijd gebruikt worden als grasland. Bedrijven in deze gebieden zijn binnen Noord-Nederland vooral melkveebedrijven en deze hebben ook vaak de derogatiestatus (Ros et al., 2018ab; Ros et al., 2019abc). Een hogere aanvoer van dierlijke mest zorgt voor een hogere beschikbaarheid van stikstof door nalevering (positief vanuit agronomisch perspectief), maar geeft ook een hoger uitspoelingsrisico van nitraat (risico voor de waterkwaliteit) - met name in periodes wanneer er geen gewas is om de $\mathrm{N}$ op te nemen. Bij blijvend grasland is dit risico door de permanente grondbedekking en hoge $\mathrm{N}$-benutting relatief laag.

Veengronden zijn van nature rijk aan stikstof én leveren dan ook veel stikstof voor gewasgroei: het landbouwkundig advies geeft bijvoorbeeld aan dat er gemiddeld meer dan $250 \mathrm{~kg} \mathrm{~N} \mathrm{ha}^{-1}$ vrijkomt voor gewasopname via natuurlijke afbraakprocessen in veenbodems. In de praktijk varieert de werkelijke $\mathrm{N}$-opname op onbemeste percelen op veen tussen 100 en $600 \mathrm{~kg} \mathrm{~N} \mathrm{ha}^{-1}$.

\subsubsection{Inzicht op basis van statistische modellen}

Op basis van perceelskenmerken en lokale en regionale data is het mogelijk om de ruimtelijke variatie in $\mathrm{N}$ - en P-concentraties in het oppervlaktewater in beeld te brengen (Ros et al., 2019abc).

Gebruikmakend van de verbanden tussen gebiedskenmerken en de gemeten stikstof en fosforconcentraties is voor elk waterschap een gebiedsdekkende kaart gemaakt die ruimtelijk inzicht geeft in de variatie in de zomergemiddelde $\mathrm{N}$ - en P-concentraties (Figuur 2.7).

- Bij het waterschap Hunze en Aa's komen hoge fosforconcentraties (>0,15 mgP/l) vooral voor in Fiemel en het noordelijke deel van Westerwolde en in het zuidelijke deel van de Veenkoloniën. Nconcentraties zijn relatief hoog in een groot deel van het beheergebied, waarbij de hoogste concentraties (> 3,0 mgN/l) voorkomen in de Veenkoloniën, Westerwolde, Oldambt en Duurswold.

- Voor het Wetterskip Fryslân blijkt dat de grootste fosforverliezen optreden in de kleirijke bodems in het noorden van het beheergebied; de P-concentraties zijn daar het hoogst $(>0,4 \mathrm{mgP} / \mathrm{I})$. Het is 
een regio die van nature hoge achtergrondconcentraties in het kwelwater heeft vanuit mariene afzettingen. De bodem is sterk verzadigd met fosfaat en in ondiep grondwater, dat in vaste peilbuizen is bemonsterd, zijn relatief hoge fosfaatgehalten gemeten. Ook zijn er indicaties dat er sprake is van bodemverdichting, waaronder de waarnemingen dat er in veel peilgebieden weinig regenwormen aanwezig zijn. Ook is er op deze bodems vaak sprake van een intensief bouwplan met veel rooivruchten. Gecombineerd zijn dit factoren die bijdragen aan een groter risico op P-verliezen naar het oppervlaktewater. De variatie in zomergemiddelde $\mathrm{N}$-concentraties zijn relatief gering: de meeste meetpunten in het oppervlaktewater (exclusief de boezem) hebben een $\mathrm{N}$-concentratie kleiner dan 1,5 $\mathrm{mg} \mathrm{N} \mathrm{L}^{-1}$.

- Voor het beheergebied van Noorderzijlvest is er sprake van een grondsoort gebonden variatie in $\mathrm{N}$ en P-concentraties. De hoogte concentraties komen voor in de bouwlanden op zeeklei in het Noorden van het beheergebied. In gebieden met veel grasland zijn de concentraties relatief laag.

Voorspelde en gemeten zomergemiddelde N-conc (2012-2018)

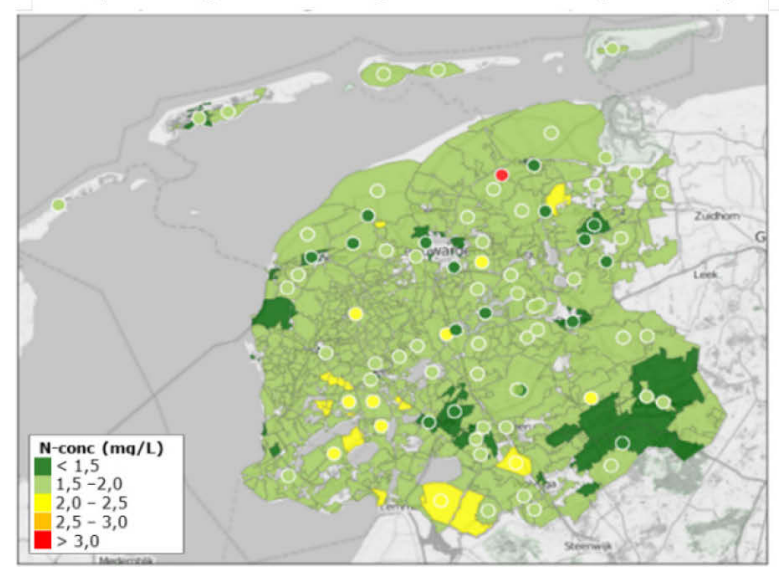

zomergemiddelde $\mathrm{N}$-conc

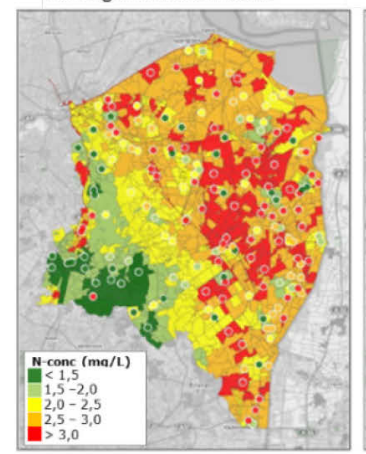

zomergemiddelde P-conc

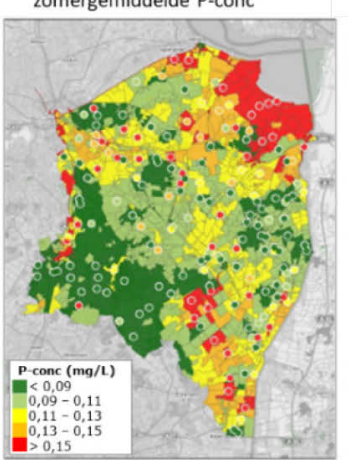

Voorspelde en gemeten zomergemiddelde P-conc (2012-2018)

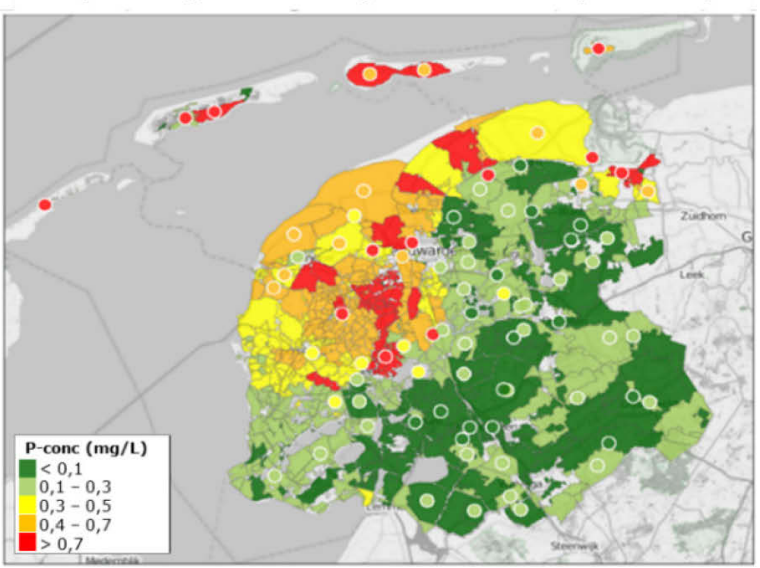

zomergemiddelde $\mathrm{N}$-conc

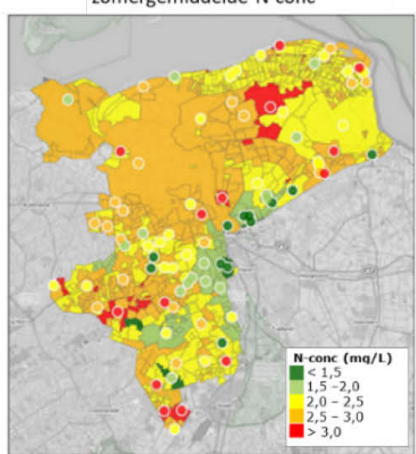

zomergemiddelde P-conc

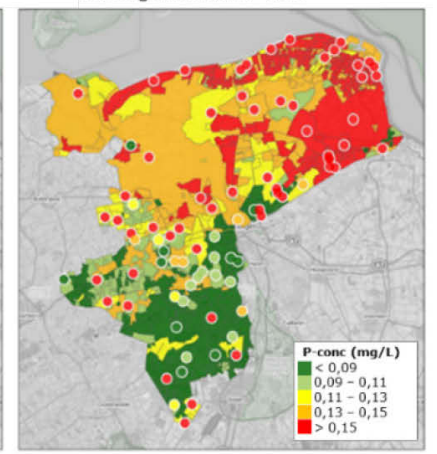

Figuur 2.7 Ruimtelijke variatie in gemeten (punten) en voorspelde zomergemiddelde (vlakken) $\mathrm{N}$ en P-concentraties in het oppervlaktewater van Wetterskip Fryslân (boven), waterschap Hunze en Aa's (linksonder) en Noorderzijlvest (rechtsonder). Let op: de gebruikte legenda varieert per waterschap en volgt de legenda van de originele publicaties.

Uit de verschillende gebiedsanalyses (Ros et al., 2018ab; Ros et al., 2019abc) wordt duidelijk dat fosfor en stikstof op een andere manier in het watersysteem terechtkomen en dat beide verliesroutes ook door andere perceelskenmerken beïnvloed worden. Fosforverliezen worden daarbij sterk gestuurd door het chemische evenwicht in de bodem en het risico op oppervlakkige afstroming en ondiepe uitspoeling vanuit de landbouwbodem. Relevante bodemkenmerken zijn de textuur, de ontwatering en de fysisch-chemische eigenschappen van de ondergrond. Stikstofverliezen worden in veel sterkere mate gestuurd door de bouwplannen (de gewaskeuze) en de daaraan gekoppelde bemestingspraktijk qua mesttype en stikstofgift. Ook hier spelen bodemtype en ontwatering een grote rol, omdat zij beïnvloeden welk deel van het $\mathrm{N}$-overschot (de vrijgekomen dan wel gegeven stikstof minus de gewasopname) denitrificeert dan wel uit- en afspoelt naar grond- en oppervlaktewater. 
Hoge(re) P-verliezen kunnen daarbij in de regionale oppervlaktewateren gebufferd worden door het ontwerp en onderhoud van watergangen: de watertemperatuur en het zuurstofgehalte zijn sterk gerelateerd aan het fosforgehalte. Diepere sloten worden minder snel opgewarmd en zijn gemiddeld genomen koeler dan ondiepere sloten. Naast de verblijftijd heeft dit gevolgen voor de processen die fosfaat vrijmaken of vastleggen in de slootbodem. Het doorzicht correleert ook met het fosforgehalte, maar dat moet gezien worden als een gevolg van de hoge P-belasting. Gebiedskennis is nodig om gericht te sturen op de belangrijkste processen die in de sloot sturend zijn op deze bufferende werking. Het juiste beheer hangt samen met de kwelsituatie (veel/weinig) als ook de P-, Fe- en Sconcentratie in het kwelwater en met de bufferende en naleverende werking van de slootbodem. Gerichte sturing op minder oppervlakkige afvoer is mogelijk via bufferzones en akkerranden. Hoge ijzerconcentraties in de sloot(bodem) kunnen daarnaast zorgen voor extra retentie in de watergang. In de kleirijke kustzones speelt daarbij een hoge natuurlijke achtergrondbelasting (hoge Pconcentraties in kwelwater en nalevering) vanuit de mariene afzettingen in de ondergrond.

In een groot deel van het agrarisch beheergebied is het bodembeheer van invloed op de benutting én op de verliezen van nutriënten naar het oppervlaktewater. Een goede bodemvruchtbaarheid, als resultante van een doordacht bouwplan, bodembeheer en bemesting, zorgt namelijk voor meer buffering in de bodem en voor minder $\mathrm{N}$ - en P-verliezen. De grootste verbetering is hier te realiseren voor stikstof, waarbij niet zozeer een lagere $\mathrm{N}$-gift, maar verhoging van de bodembenutting gewenst is. Inzet van precisiebemesting en de inzet van vanggewassen kunnen hierbij helpen. Internationaal wordt in de agronomie vanuit duurzaamheidsoogpunt dan ook gestuurd op de 4xR-strategie (right amount, place, timing and composition). Ofwel, dat de mest op de juiste plaats, het juiste tijdstip, de juiste samenstelling en met de juiste dosering wordt toegediend. Zeker voor stikstof liggen hier mogelijkheden om het $\mathrm{N}$-overschot zodanig te verlagen dat het risico op verliezen kleiner wordt.

Voor fosfaat liggen de belangrijkste sturingsvariabelen in het beïnvloeden van de emissieroutes (het afvangen oppervlakkige afstroming, voorkomen afkalving of vertrappen slootoevers) en het vergroten van de retentie in het oppervlaktewater (inclusief slootpeilen, breedte van de watergang, en verblijftijden). De P-voorraden in de bodem zijn namelijk groot en vormen een substantiële bron van $\mathrm{P}$ dat kan uitspoelen richting het watersysteem. Dit effect van de bodem P-voorraad is in de praktijk vaak minder zichtbaar, omdat de P-toestand van de bodem en de P-verzadiging van de bodem- en ondergrond vrijwel overal hoog zijn. Het wordt wel concreet in een positief verband met de hoeveelheid plant-beschikbaar fosfaat, dat wil zeggen de concentratie P die in de bodemoplossing aanwezig is. Dit P-gehalte in de bodemoplossing reflecteert sterk de mesthistorie: percelen die veel mest krijgen, hebben een relatief hoger P-gehalte in de bodemoplossing dan percelen die weinig mest krijgen. Er is dan ook een positief verband tussen de hoogte van de verschillende P-pools in de bodem (waaronder de P-concentratie in bodemvocht) en de concentraties in het oppervlaktewater. De huidige P-toestand van de bodem en de bemestingspraktijk om de P-norm op te vullen, zijn wel een aandachtspunt.

De tweede belangrijke stuurfactor - naast bemesting en bodembeheer - heeft te maken met de ontwatering van percelen en het landgebruik. Bouwplannen met relatief veel diep wortelende en $\mathrm{N}$ efficiënte gewassen zoals granen en gras hebben relatief minder $\mathrm{N}$-uitspoeling dan bouwplannen met veel rooivruchten. Om deze reden heeft bemesting voor stikstof meer invloed in de Veenkoloniën en Westerwolde dan in de Drentsche Aa en Duurswold, omdat in de veenkoloniën minder gras en granen worden geteeld. Door intensieve bodembewerking en ruggenteelten in de akkerbouw is er vooral op de zandgronden een verhoogd risico op $\mathrm{N}$ - en $\mathrm{P}$-afspoeling en staat de bodemkwaliteit onder druk. Deze conclusies corresponderen met de analyse van Van der Grift (2011) voor het watersysteem van de Drentsche Aa en de Schuitenbeek, waar het grootste deel van de N-vracht naar het oppervlaktewater uit het bovenste grondwater in droge landbouwgebieden komt. Sturen op stikstofbemesting en bodemvruchtbaarheid is daarom het effectiefst om de N-belasting te verlagen. Fosfor geeft een ander beeld: de natte venige en moerige gebieden leveren het merendeel van de Pvracht vanuit het grondwater. Hoge ijzerconcentraties in het diepe grondwater zorgen overigens voor vastlegging van $P$ in de slootbodem. 
Op basis van de gemeten kenmerken van het bodem- en watersysteem is voor Wetterskip Fryslân en waterschap Hunze en Aa in kaart gebracht welke factoren sturend zijn in de variatie in stikstof- en fosfaatconcentraties in de zomer, geclusterd per categorie (Figuur 2.8).
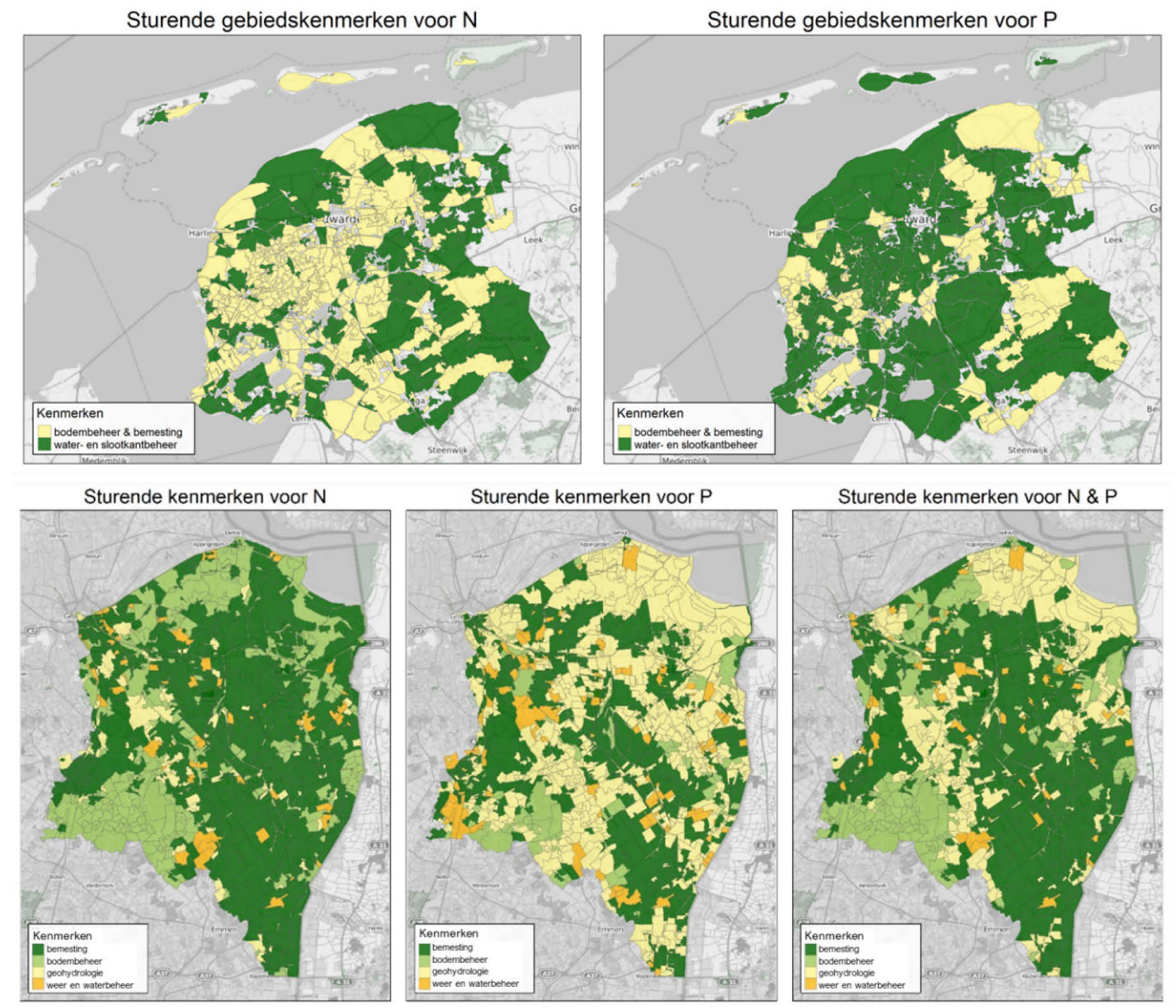

Figuur 2.8 Ruimtelijke weergave van de meest sturende gebiedskenmerken (gegroepeerd per type en geselecteerd uit de top 40-kenmerken voor zowel stikstof als fosfor) die van invloed zijn op het verschil in gemeten $N$ - en $P$-concentraties binnen het beheergebied van Wetterskip Fryslân (boven) en het waterschap Hunze en Aa's (onder). Let op: de gebruikte legenda varieert tussen beide beheergebieden (zie voor achtergronden de oorspronkelijke studies).

De ruimtelijke variatie in de zomergemiddelde P-concentraties binnen Wetterskip Fryslân blijkt sterk samen te hangen met het bodemtype en moedermateriaal: variabelen die gerelateerd zijn aan de gehaltes van metalen en nutriënten in de ondergrond, de fosfaattoestand van de bovengrond, de zuurgraad (gekoppeld aan kalkrijke afzettingen), de geschatte wegzijgingsflux en de afbreekbaarheid van de aanwezige organische stof zijn de belangrijkste sturende variabelen. De aanwezigheid van kwel en het watertype spelen daarnaast een belangrijke rol. In $74 \%$ van de peilgebieden binnen Wetterskip Fryslân zijn de vormgeving van het watersysteem, de geohydrologie en het water- en slootkantbeheer de belangrijkste sturende factor voor de ruimtelijke variatie in $\mathrm{P}$-concentraties. In de overige $26 \%$ van de peilgebieden zijn het vooral gebiedskenmerken die samenhangen met de bodemkwaliteit alsook het landgebruik en bemesting. Voor stikstof is dit patroon diffuser en speelt agrarisch bodembeheer en bemesting een grotere rol: in $66 \%$ van de peilgebieden zijn dit de relevantste gebiedskenmerken die van invloed zijn op de ruimtelijke variatie in $\mathrm{N}$-concentraties. Daarbij gaat het onder andere om de bodemkwaliteit (o.a. de biochemie van de ondergrond, het $\mathrm{N}$-overschot, de Ca-bezetting van de CEC en het risico op verdichting), de bodemvruchtbaarheid (zichtbaar in soortenrijkdom van wormen en de 
P-voorraad), het landgebruik en de ontwatering. Vergelijkbare inzichten worden gevonden voor het beheergebied van Hunze en Aa's.

De belangrijkste gebiedskenmerken die samenhangen met de ruimtelijke variatie in $\mathrm{N}$ - en $\mathrm{P}$ concentraties liggen primair in het watersysteem zelf. Dit betekent ook dat het beheer van het watersysteem (slootdiepte, slootkantenbeheer, inlaatregime, peilbeheer, aanwezigheid van kwel) van grote invloed is. Deze kenmerken kunnen een eventuele belasting van het watersysteem met stikstof of fosfaat bufferen. De ruimtelijke variatie in $\mathrm{N}$-totaal in het oppervlaktewater wordt sterk beïnvloed door het weer (verdamping en neerslag), de hoeveelheid bemesting met dierlijke mest, de aanvoer van $\mathrm{N}$ via depositie en het gehalte (en kwaliteit van) organische stikstof in de bodem. Voor totaalfosfor zijn deze parameters deels vergelijkbaar (vooral die gerelateerd zijn aan weer), maar spelen kenmerken van het bodem- en watersysteem een grotere rol dan voor stikstof.

De geselecteerde gebiedskenmerken zijn indirect ook sturend op de resultaten van het STONEinstrumentarium. Gedetailleerde STONE-toepassingen voor zes peilgebieden binnen Friesland (Van Boekel et al., 2017) laten bijvoorbeeld zien dat de bijdrage van 'actuele bemesting' grotendeels samenhangt met het voorkomen van maaiveldgreppels waardoor de lokale ontwatering, de drainageweerstand en slootdichtheid de cruciale factoren zijn die de P-belasting sturen. De conclusies van dit onderzoek zijn daarom complementair aan de conclusies van STONE.

\subsection{Aandachtspunten}

De gebiedskenmerken die sturend zijn op hogere $\mathrm{N}$ - en P-concentraties komen voor het grootste deel van Noord-Nederland met elkaar overeen. Statistische benaderingen bieden hierbij veel potentie, omdat hiermee maatwerk mogelijk kan worden gemaakt tot op het niveau van percelen. Een daadwerkelijke toetsing van deze aanpak heeft op dit moment echter nog niet plaatsgevonden. Mechanistische modellen daarentegen bieden onderbouwd inzicht in de mogelijke verbanden tussen de bronnen van stikstof en fosfor en de mogelijke verliezen die optreden naar het oppervlaktewater. De gebruikte meetgegevens en de onzekerheid op de modelresultaten zorgen er echter ook voor dat de conclusies vooral robuust zijn op het schaalniveau van peilgebieden en stroomgebieden. Het gebruik ervan voor lokale toepassingen levert een grote mate van schijnnauwkeurigheid op.

De gebruikte statistische studies laten zien dat beide benaderingen daarin complementair zijn. We (voor)zien daarom veel potentie in de koppeling van de gebruikte brondata, de statistische modellen en het STONE-instrumentarium, omdat hiermee data van specifieke percelen, onderbouwde relaties tussen perceelskenmerken en zomergemiddelde $\mathrm{N}$ - en $\mathrm{P}$-concentraties én mechanistische procesrelaties zo gekoppeld kunnen worden, dat er per perceel inzicht ontstaat in de daadwerkelijke risico's van $\mathrm{N}$ - en P-afspoeling en uitspoeling. Om deze koppeling te realiseren, is er echter nog een aantal praktische en theoretische knelpunten op te lossen. Omdat dat binnen de context van deze studie niet mogelijk was, is gekozen voor een verdere detaillering van perceelgegevens binnen het bestaande STONE-instrumentarium. Bijkomende reden was de gewenste koppeling met het oppervlaktewatermodel van Deltares.

In het opnieuw berekenen van de af- en uitspoeling voor het landelijk gebied van Rijn-Noord en Nedereems (volgende hoofdstuk) is rekening gehouden met de volgende aandachtspunten:

a. de omvang van oppervlakkige afstroming die met name voor fosfor een belangrijk deel van de afen uitspoeling kan bepalen.

b. In de NMI-studies is met Eurofins-data veel informatie over de bodemkwaliteit van landbouwbodems beschikbaar gekomen. Deze informatie kan met name bijdragen om de oppervlakkige afstroming van nutriënten te kwantificeren.

c. De af- en uitspoeling is in gebieden met kwel naast mestgiften ook voor een belangrijk deel afhankelijk van de fosfaat- en ammoniumgehalten van het kwelwater. Voor het ontwikkelen van het Landelijk Waterkwaliteit Model (LWKM) zijn nieuwe kaarten gemaakt voor de concentraties van fosfaat en stikstof in het grondwater op een diepte van 10 à $20 \mathrm{~m}$-mv, dat representatief wordt verondersteld voor de kwel naar het bodemprofiel. 
d. De berekeningen van STONE kunnen ten opzichte van de landelijke modelschematisatie regionaal beter toepasbaar worden gemaakt door die rekeneenheden te selecteren die in een fijnere regionale schematisering ( $25 \times 25 \mathrm{~m}$ ) goed passen bij de landgebruikskaart (LGN7), bodemkaart en grondwatertrappenkaart.

In de modelberekeningen is steeds aangenomen dat de mestgiften de gebruiksnormen niet of nauwelijks overschrijden. In een recente studie naar landbouw en de KRW-opgave voor nutriënten (Schipper et al., 2020) is voor grote delen in de Maasregio een belangrijke mate van overbemesting (hogere giften dan de wettelijke gebruiksnormen) met het mestverdelingsmodel INITIATOR berekend, die een belangrijke invloed heeft op de uit- en afspoeling, ammoniakemissies en nitraatuitspoeling. In hoeverre deze overbemesting daadwerkelijk voorkomt, kon in die studie niet worden getoetst. De resultaten corresponderen wel met berekeningen door het CBS en PBL (Van Bruggen et al., 2017). In een landelijke modelstudie met INITIATOR naar de allocatie van de mestgiften en ammoniakemissies (Kros et al., 2019) is voor het jaar 2015 ook in Rijn-Noord enige overbemesting berekend, voornamelijk in het gebied van Wetterskip Fryslân. De mate van deze berekende overbemesting (5 à $25 \mathrm{kgN} / \mathrm{ha} / \mathrm{j}$ en 2,5 à $5 \mathrm{kgP} / \mathrm{ha} / \mathrm{j}$ ) is echter veel kleiner dan in de Maasregio. Wel is de indruk dat de mate van overbemesting vanaf 2015 verder is toegenomen door de afschaffing van het melkquotum en aanscherping van de gebruiksnormen. Ook wordt de huidige beschikbare P-ruimte meer opgevuld dan vroeger (voor 2006) het geval was (Ros et al., 2018).

De mestverdelingsberekeningen kennen echter belangrijke onzekerheden, vooral het verloop van overbemesting in de toekomst is onzeker. In navolging van deze studie wordt aanbevolen om de aannames van het mestverdelingsmodel steviger te onderbouwen en onzekerheden beter te kennen en te duiden. Dit is conform de aanpak van de Nationale Analyse Waterkwaliteit die stelt: "Het is onmogelijk om de effecten van toekomstig beleid te berekenen als tegelijkertijd de mogelijkheid open wordt gehouden - zoals bij 'overbenutting' het geval kan zijn - dat niet iedereen zich houdt aan dat beleid." (Van Gaalen et al., 2020). 


\section{Modelberekeningen af- en uitspoeling}

\subsection{Inleiding}

Voor de synthese is de af- en uitspoeling van nutriënten naar het oppervlaktewater vanuit landbouwen natuurgronden opnieuw berekend met het STONE-instrumentarium (zie Bijlage 1 voor een algemene toelichting van STONE). Conform de eerder beschreven aanbevelingen (sectie 2.4) is een aantal aanpassingen doorgevoerd om een beter beeld te krijgen van de ruimtelijke en temporele variatie in $\mathrm{N}$ - en P-afspoeling en uitspoeling naar het grondwater. In de berekeningen zijn de volgende stappen uitgevoerd:

- Regionalisatie STONE-rekeneenheden (herschikken SWAP-Animo rekenplots);

- Aanpassing kwelconcentraties (onderrandvoorwaarde) in de STONE-rekeneenheden;

- Modellering van de afspoeling van fosfor met een nieuwe methodiek, waarbij onder andere gebruik wordt gemaakt van de P-toestand van de bodem (conform de ruimtelijke kaarten die gebaseerd zijn op de door het NMI statistisch bewerkte meetgegevens uit agrarische meetnetten).

Deze stappen worden in de volgende paragrafen behandeld.

\subsection{Regionalisatie (herschikken) rekenplots}

Zoals aangegeven, is STONE ontwikkeld voor toepassing op landelijke schaal met een landelijke schematisering bestaande uit 6.405 rekeneenheden (SWAP-ANIMO rekenplots). Een rekenplot bestaat uit een unieke combinatie van hydrologische eigenschappen, landgebruik en bodemkenmerken en heeft een resolutie van $250 \times 250 \mathrm{~m}$. De kenmerken van deze rekenplots kunnen voor een regionale toepassing beter afgestemd worden op de regio-specifieke situatie via een herschikkingsprocedure (Van Boekel et al., 2013). In deze paragraaf wordt de methodiek kort toegelicht. Een uitgebreidere beschrijving staat in Bijlage 1.

De eerste stap in de herschikkingsprocedure is het genereren van een zogenaamde MLBG-kaart op basis van de gebiedskenmerken (Meteodistrict, Landgebruik, Bodemtype en Grondwatertrap). De volgende kaarten zijn hierbij gebruikt:

- Meteodistricten op basis van PAWN-districten (Kroes et al., 1999; Kroon et al., 2001);

- Landgebruik op basis van het LGN7-bestand (Hazeu et al., 2014);

- Bodemtype op basis van de 1:50.000 Bodemkaart (Klijn, 1997);

- Grondwatertrap (Gt-klasse) op basis van de 1:50.000 Bodemkaart (Klijn, 1997).

De P-toestand van de bovenste bodem is wel meegenomen in nieuwe berekeningen van de oppervlakkige afspoeling (zie paragraaf 3.4), maar niet in de herschikking, omdat voor de uitspoeling de fosfaattoestand in de diepere bodemlagen vooral bepalend is. Vanuit de uitgevoerde studies blijkt dat er nog relatief weinig bekend is over de P-concentraties in de bodemlaag onder de bouwvoor.

De kaartlagen zijn gecombineerd tot één kaartlaag met unieke MLBG-eenheden met een resolutie van $25 \times 25 \mathrm{~m}$. Deze MLBG-kaart is de input voor de tweede stap van de herschikkingsprocedure.

In de tweede stap zijn voor alle MLBG-eenheden representatieve rekenplots gezocht. Bij de zoektocht naar representatieve rekenplots kunnen zich meerdere situaties voordoen:

1. Er worden meerdere representatieve rekenplots per eenheid gevonden. Wanneer er sprake is van meerdere rekenplots wordt een gemiddelde af- en uitspoeling naar het oppervlaktewater berekend. Er is gekozen voor een gemiddelde, zodat dit altijd tot dezelfde resultaten leidt.

2. Er wordt één representatieve rekenplot gevonden. Indien er één rekenplot wordt gevonden, dan wordt de berekende af- en uitspoeling van deze plot toegekend aan een MLBG-eenheid. 
3. Er kunnen geen rekenplots gevonden worden die voldoen aan de opgelegde criteria. Indien er geen representatieve rekenplots gevonden worden, is ervoor gekozen om stapsgewijs steeds meer informatie van de MLBG-eenheden los te laten, net zolang totdat alle eenheden zijn voorzien van een koppeling aan STONE-plots. Het stappenplan voor de toekenning van STONE-plots aan MLBGeenheden is beschreven in Bijlage 1 . In de zoektocht naar representatieve rekenplots bij geen fit is voor de landgebruik-, bodemtype-, GT- en meteoregio-combinatie gezocht naar rekenplots met redelijk vergelijkbare bodemtypen en redelijk vergelijkbare GT's. De aansluiting op de onderscheiden klassen qua landgebruik en meteoregio wordt in de selectieprocedure niet losgelaten (harde criteria). Nadat alle stappen zijn doorlopen, is het mogelijk om aan elke MLBGeenheid een stikstof- en fosforvracht toe te kennen.

De herschikking is uitgevoerd op het niveau van de afwateringsgebieden die voor de modellering van het oppervlaktewater met SOBEK worden onderscheiden. Deze afwateringsgebieden zijn weergegeven in Figuur 3.1. De beheersgebieden van Wetterskip Fryslân, Hunze \& Aa's en Noorderzijlvest zijn hiermee onderverdeeld in respectievelijk 38, 11 en 8 afwateringsgebieden.

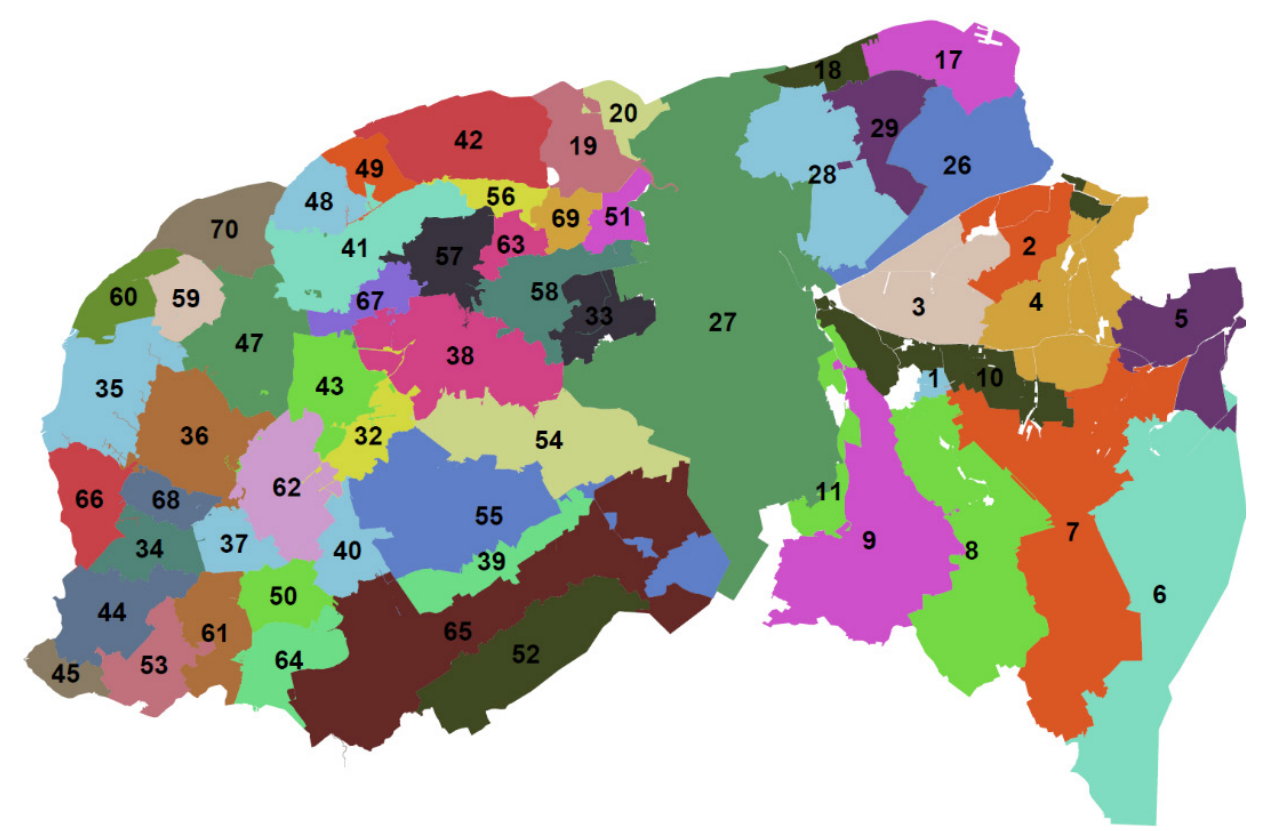

Figuur 3.1 Stroomgebieden in Rijn-Noord en hun nummering.

\subsection{Aanpassing kwelconcentraties}

De kwelconcentraties van het grondwater worden gebruikt om de onderrandwaarden te definiëren en om de initiële concentraties te berekenen in het traject tussen de wortelzone en de onderrand (Renaud et al., 2017). Voor het studiegebied lijken de concentraties die per GeoTOP-gebied zijn bepaald door TNO (Griffioen et al., 2006) het representatiefst. GeoTOP geeft een gedetailleerd driedimensionaal beeld van de ondergrond tot een diepte van maximaal 50 m onder NAP). Om zo goed mogelijk hierbij aan te sluiten, zijn de concentraties van het kwelwater aangepast waar deze na het herschikken afwijken.

Hierbij is als volgt gewerkt:

a. Per afwateringsgebied is van de in dat gebied met herschikking geselecteerde STONE-plots de areaal gewogen kwelconcentratie afgeleid.

b. Per afwateringsgebied is in GIS de gemiddelde kwelconcentratie afgeleid van de studie van Griffioen waarbij de concentraties op GEOTOP zijn aangegeven.

c. In de afwateringsgebieden, waar het verschil tussen a) en b) groter is dan $10 \%$, is de concentratie van de kwel in de STONE-plots daarop aangepast.

d. Met deze nieuwe onderrandvoorwaarde zijn de STONE-plots opnieuw geïnitialiseerd en langjarig doorgerekend tot en met 2017. 
Figuur 3.2 geeft de kwelconcentraties die initieel en na aanpassing zijn aangehouden in het berekenen van de af- en uitspoeling met de rekeneenheden van SWAP-ANIMO. Met de aanpassing zijn in enkele noordwestelijke en oostelijke gebieden hogere concentraties stikstof- (ammonium) en fosfor- (fosfaat) concentraties als onderrandvoorwaarde in de modelberekeningen aangehouden. Hiermee zijn de modelprofielen opnieuw doorgerekend.
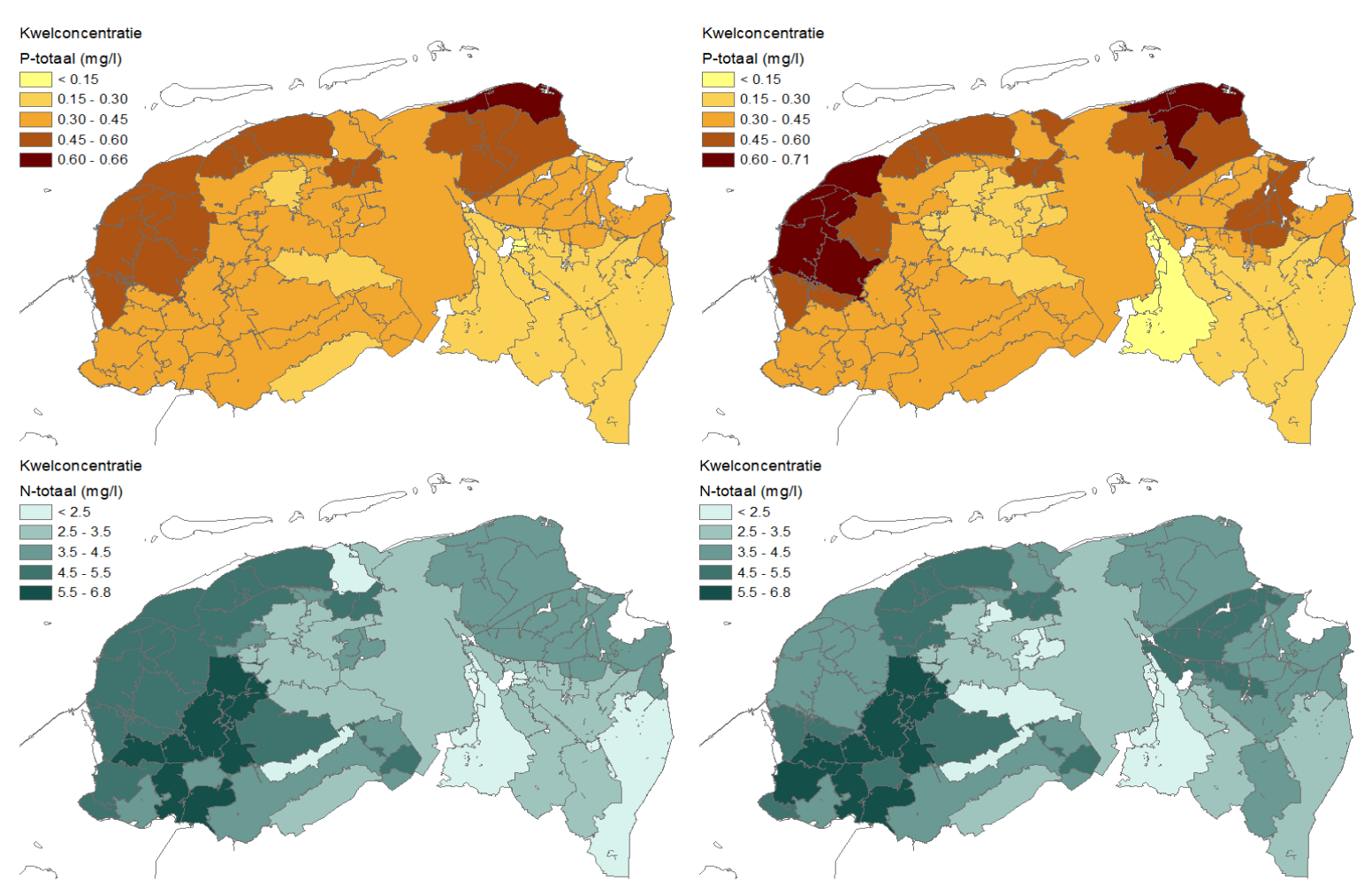

Figuur 3.2 Initiële kwelconcentraties (links) en zoals na aanpassing (rechts) ingevoerd in de nieuwe berekening van de af- en uitspoeling met SWAP-ANIMO.

\subsection{Modellering oppervlakkige afspoeling fosfor}

\section{Methode}

De hoeveelheid fosfor die via oppervlakkige afstroom vanuit het perceel in het oppervlaktewater komt, is bepaald in drie stappen:

1. Schatten hoeveel water er jaarlijks oppervlakkig afstroomt per perceel $\left(q_{\text {runoff }}\right)$, op basis van perceelskenmerken.

2. Schatten welke P-concentratie dit afstromend water heeft ( $c_{\text {runoff }}$ ) per perceel op basis van Eurofins-metingen van de fosfaatverzadiging van de bovengrond.

3. De P-vracht berekenen die per perceel is gemoeid met oppervlakkig afstroom ( $=q_{\text {runoff }} * c_{\text {runoff }}$ ). Deze P-vracht is waar nodig afgekapt, zodat de P-vracht door oppervlakkige afstroom nooit groter is dan $75 \%$ van de totale uit- en afspoeling van $P$ zoals berekend met STONE. Deze aanname is gedaan, omdat er met deze methode geen onderbouwing ligt om de totale uit- en afspoeling naar boven bij te stellen en het op basis van expert-kennis niet aannemelijk lijkt om een nog groter aandeel van de oppervlakkige afspoeling aan te nemen.

Stap 1: bepalen oppervlakkige afstroom

Voor elk landbouwperceel dat grenst aan water is ingeschat hoeveel water er oppervlakkig afstroomt richting oppervlaktewater $\left(q_{\text {runoff }}\right)$ :

$$
q_{\text {runoff }}=q_{\text {Horton, ref }} \times\left(\frac{24}{\text { afstand tot waterloop }}\right)^{0.5}\left(\frac{\text { helling }}{0.89}\right)^{0.5}+q_{\text {Dunne }}
$$


Hiervoor zijn perceelskenmerken gebruikt (de afstand tot de waterloop, de helling, het bodemtype en de grondwatertrap) zoals bepaald voor de BasisRegistratiePercelen kaart 2018 (BRP2018) in het Kennisimpuls-Waterkwaliteit project 'Maatregel op de kaart' (Van Gerven et al., 2019).

Zoals te zien in formule 1.1 bestaat de berekende run-off $\left(q_{\text {runoff }}\right)$ uit 'Horton overland flow' $\left(q_{\text {Horton }}\right)$, die ontstaat als grond dichtslaat en uit 'Dunne overland flow' $\left(q_{\text {Dunne }}\right)$, die ontstaat als de onderliggende bodem verzadigd is. Aangenomen is dat de gemiddelde Horton-flow ( $q_{\text {Horton, ref }}$ ) $20 \mathrm{~mm} / \mathrm{jaar}$ bedraagt voor een standaard perceel op veen, klei of löss en $10 \mathrm{~mm} / \mathrm{jaar}$ voor een standaard zandperceel. Zo'n standaard perceel heeft een mediane afstand tot de waterloop (afstand tot waterloop) van 24 m en een mediane helling (helling) van 0,89\%, zoals blijkt uit een dataset van alle landbouwpercelenpercelen in Nederland (Van Gerven et al., 2019). De Horton-flow neemt toe naarmate het perceel dichter bij de waterloop ligt en een steilere helling heeft. De Dunne-flow hangt af van de grondwaterstand en is geschat op $35 \mathrm{~mm} / \mathrm{jaar}$ voor natte percelen (GT Ia, IIa, IIIa, Vao en Vad), $15 \mathrm{~mm} /$ jaar voor redelijk natte percelen (GT Ic, IIb, IIIb, Vbo en Vbd), $5 \mathrm{~mm} /$ jaar voor percelen met GT IIc en 0 mm/jaar voor droge percelen ( $\mathrm{G} \geq \mathrm{VI}$ ). De kaarten in Figuur 3.3 tonen de perceelskenmerken die als basis gebruikt zijn bij het kwantificeren van de oppervlakkige afstroming: de mediahelling van het maaiveld, de grondsoort en grondwatertrap.

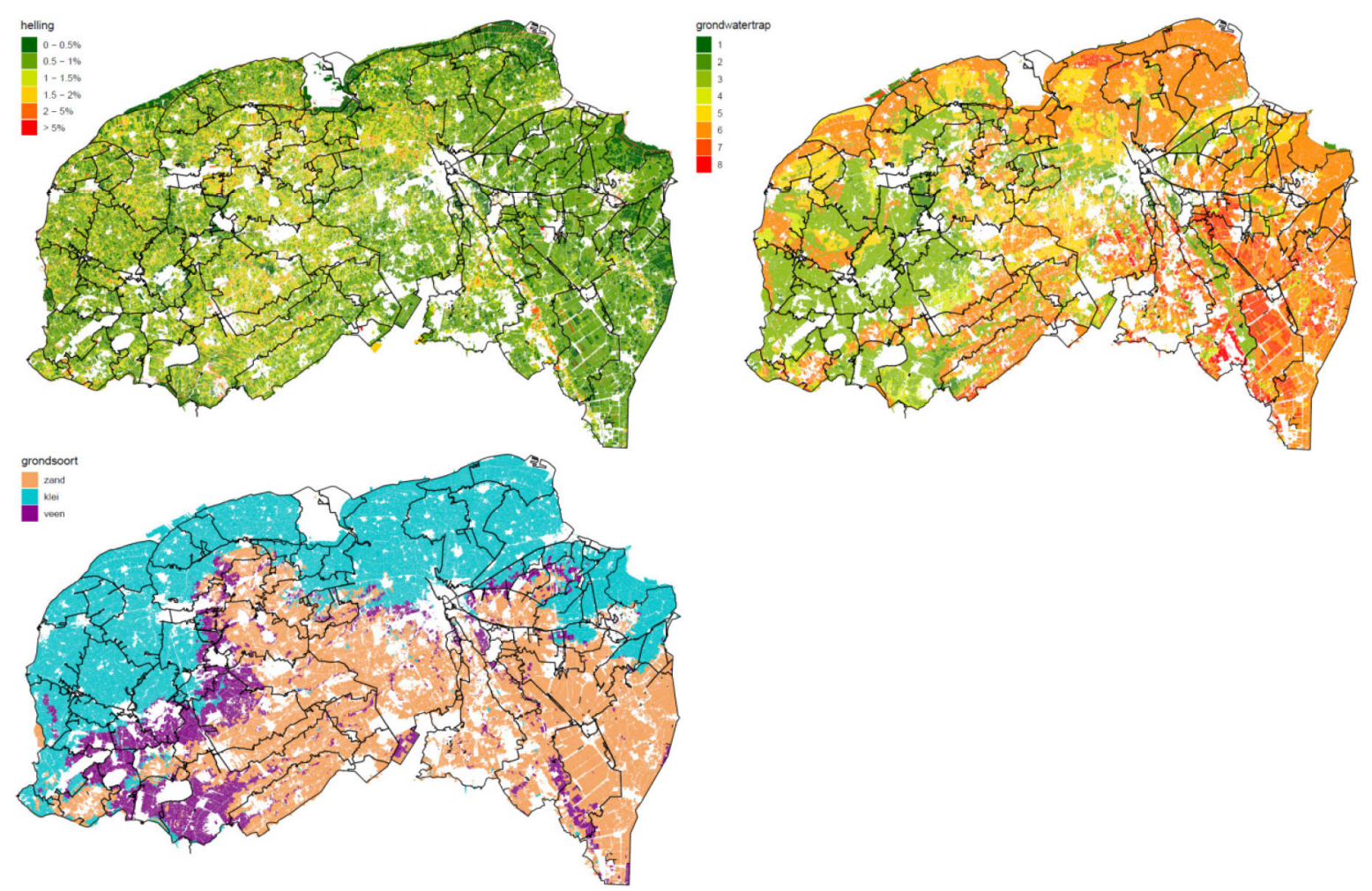

Figuur 3.3 Perceelskenmerken die zijn gebruikt om de kans op oppervlakkige afstroom te bepalen: mediane helling (linksboven), grondwatertrap (rechtsboven) en grondsoort (beneden).

Stap 2: Afleiden P-concentratie van runoff-water met fosfaatmetingen van bovengrond Vervolgens is geschat welke P-concentratie het afstromende perceelwater heeft. Dit is gedaan in twee stappen. Allereerst is de fosfaattoestand per perceel bepaald door Eurofins-metingen van het Pw-getal te koppelen aan perceelskenmerken via 'machine learning'. Het resulterende Pw-getal per perceel is een maat voor de fosfaattoestand van de bodem: het geeft de hoeveelheid fosfaat die in de bodemoplossing voorkomt plus een deel van de hoeveelheid makkelijk uitwisselbaar fosfaat. Als tweede stap is dit Pw-getal (uitgedrukt in mg fosfaat per liter grond) vertaald naar de fosfaatconcentratie van het oppervlakkig afstromende water ( $c_{\text {runoff }}$ uitgedrukt in $\mathrm{mg}$ fosfaat per liter water), door het Pw-getal te delen door 40. De gevonden range aan Pw-getallen van 20 tot 100 in Noord-Nederland resulteren dan in een P-concentratie van het afstromende water van 0,5 tot 2,5 mg $\mathrm{P}$ per liter. Dit is in dezelfde ordegrootte als literatuurwaarden van gemeten P-concentraties in run-offwater. 
Figuur 3.4 toont de afgeleide jaargemiddelde hoeveelheid run-off van water en de geschatte Pconcentraties van het run-off-water. Deze geschatte P-concentraties liggen tussen de 1 en 2 mg P per liter, met enkele lokale uitschieters. Deze uitschieters liggen vooral in het beheergebied van Wetterskip Fryslân. Een mogelijke verklaring is dat hier relatief veel dierlijke mest wordt uitgereden, want in de studie naar de mestgiften in 2015 (Kros et al., 2019) is in het gebied van RBO-noord voornamelijk in het westelijke en centrale deel van Fryslân overbemesting berekend.

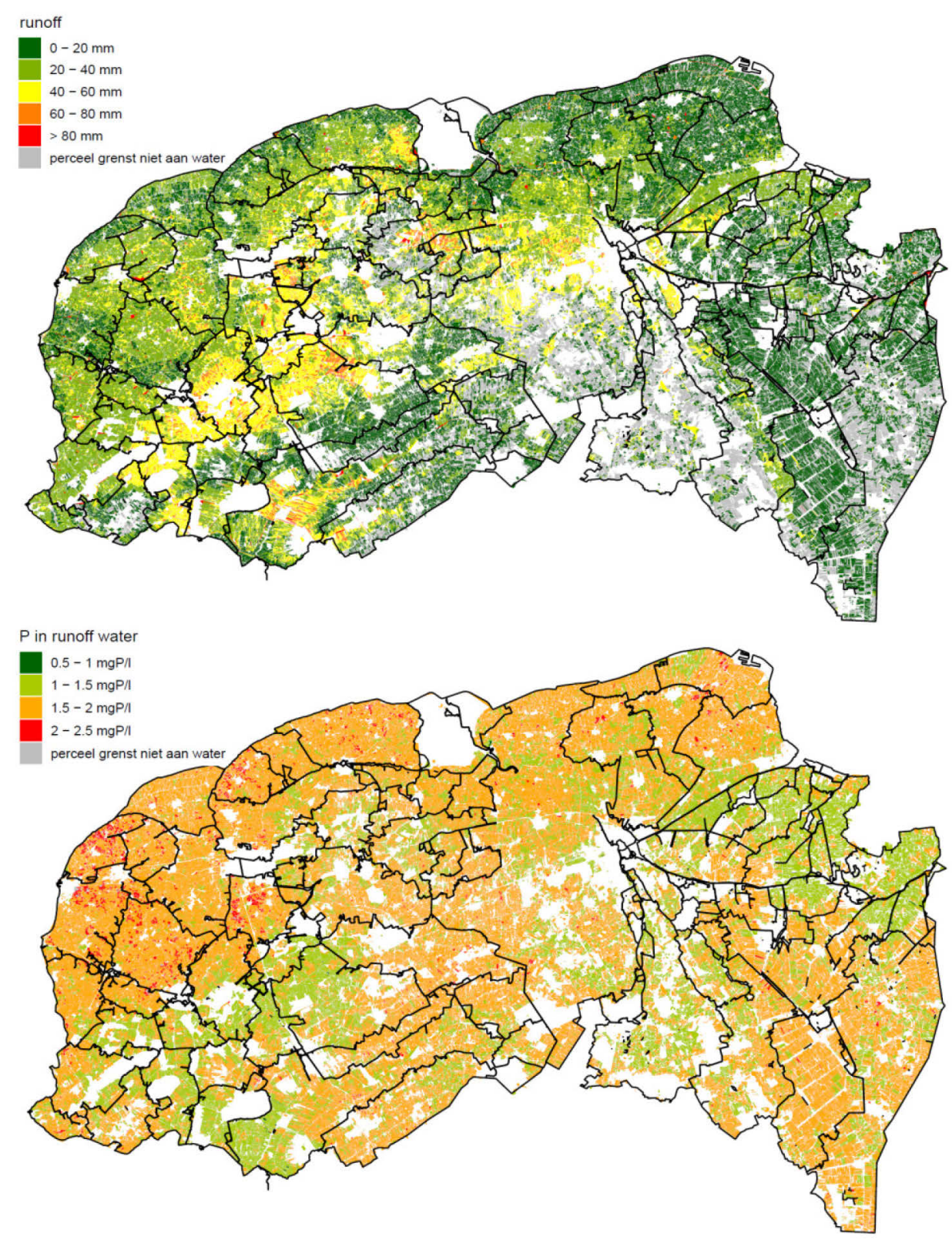

Figuur 3.4 Berekende jaargemiddelde run-off van water (boven) en de geschatte P-concentratie van het run-off-water volgend uit Eurofins-metingen van de bovengrond (onder).

Stap 3: De P-vracht door run-off bepalen en eventueel naar beneden bijstellen Als laatste stap is per perceel de P-vracht berekend door oppervlakkige afstroom ( $=q_{\text {runoff }} * c_{\text {runoff }}$ ). Deze P-vracht is waar nodig naar beneden bijgesteld, zodat de P-vracht door oppervlakkige afstroom nooit groter is dan $75 \%$ van de totale jaargemiddelde uit- en afspoeling van $\mathrm{P}$ zoals berekend met STONE over de periode 2010-2017. Deze bijstelling was nodig voor ongeveer $15 \%$ van de percelen in Noord-Nederland. Voor de meeste percelen ging het om een kleine bijstelling tot 0,2 kg P / ha / jaar.

Modelresultaten oppervlakkige afstroming fosfor

De berekende hoeveelheid $\mathrm{P}$ die is gemoeid met perceel-run-off is weergegeven in Figuur 3.5. Deze is vanwege de gedane aannames niet zoals de voorgaande figuren op perceelsniveau weergegeven, maar 
op een grover detailniveau (kilometergrid). Te zien is dat vooral de klei- en veengebieden gevoelig zijn voor P-run-off, met enkele hotspots in de gebieden met hoge grondwaterstanden. Figuur 3.6 toont een kaart waarin per perceel de kans voor het optreden van oppervlakkige afstroming kwalitatief is aangegeven.

De hoog berekende P-afspoeling in het centrale deel van Fryslân (globaal tussen het Sneekermeer en Grou) komt volgens het Wetterskip Fryslân goed overeen met de locaties waar in het oppervlaktewater hoge P-concentraties worden gemeten.

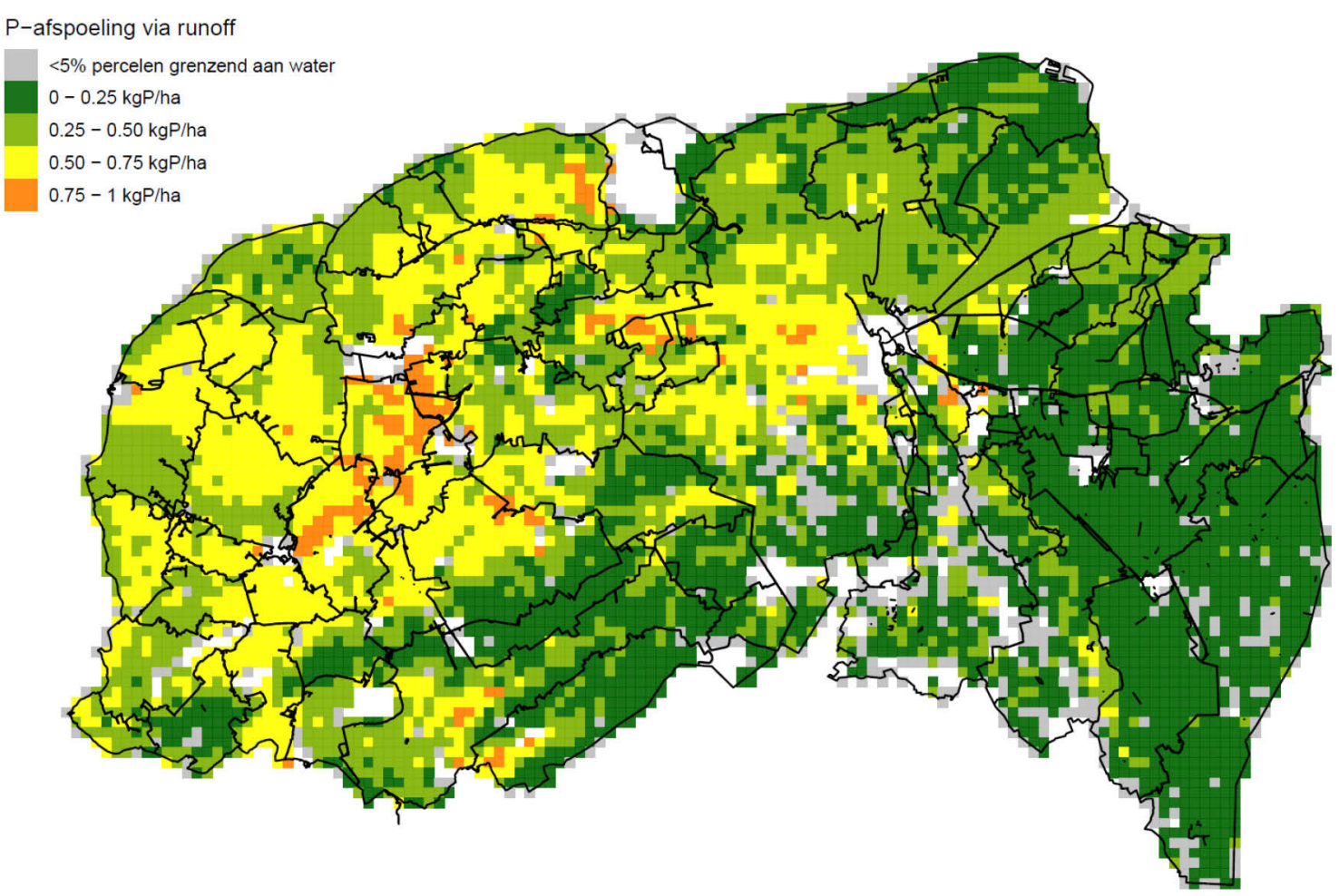

Figuur 3.5 Berekende jaargemiddelde hoeveelheid P die is gemoeid met oppervlakkige afstroom.

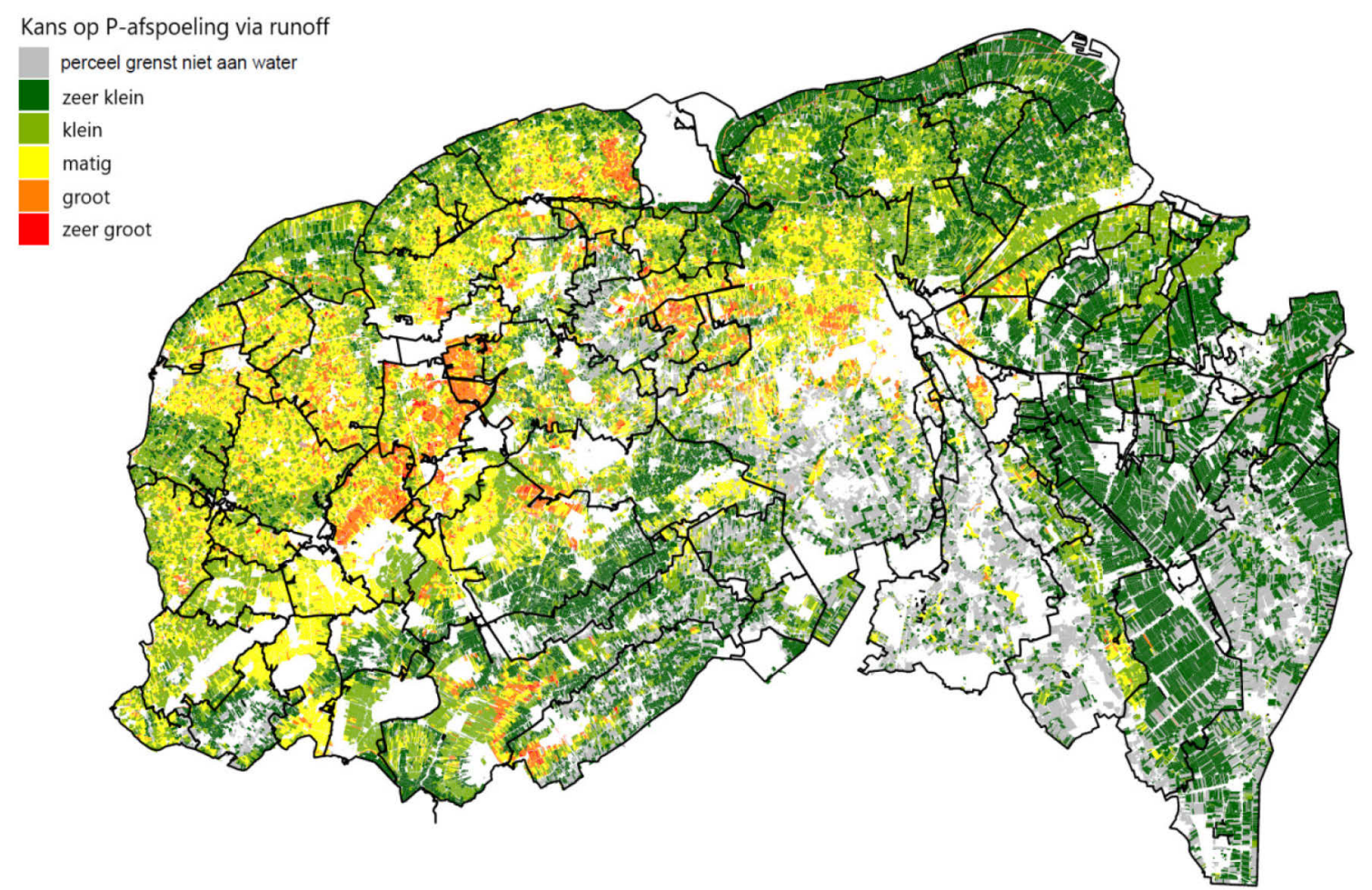

Figuur 3.6 De berekende kans op oppervlakkige afstroming van fosfor. 


\subsection{Gecombineerde modelresultaten af- en uitspoeling}

De af- en uitspoeling zoals berekend met de herschikte STONE-rekenplots en de hierin aangepaste kwelconcentraties op de onderrand zijn berekend voor de periode 2010 tot en met 2017. De totaal berekende af- en uitspoeling (bij elkaar opgeteld) van stikstof is voor landbouw en natuurgronden weergegeven in Figuur 3.7. De totaal berekende af- en uitspoeling van fosfor zoals berekend met de STONE-plots is weergegeven in Figuur 3.8. In Bijlage 3 zijn dezelfde figuren opgenomen, maar dan uitsluitend de af- en uitspoeling vanaf landbouwgronden.

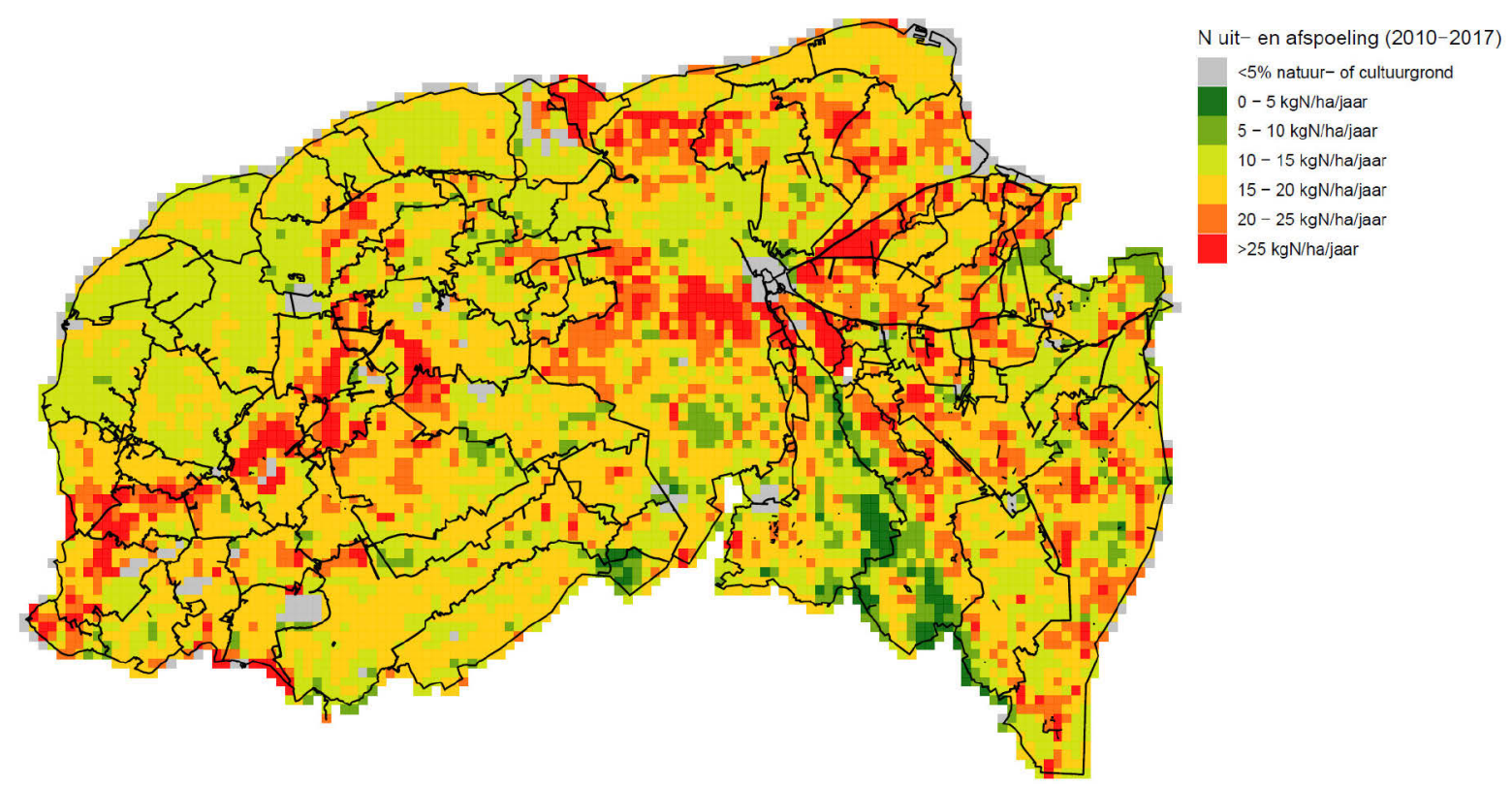

Figuur 3.7 Jaargemiddelde uit- en afspoeling van stikstof vanuit landbouw- en natuurgronden naar het oppervlaktewater over de periode 2010-2017.

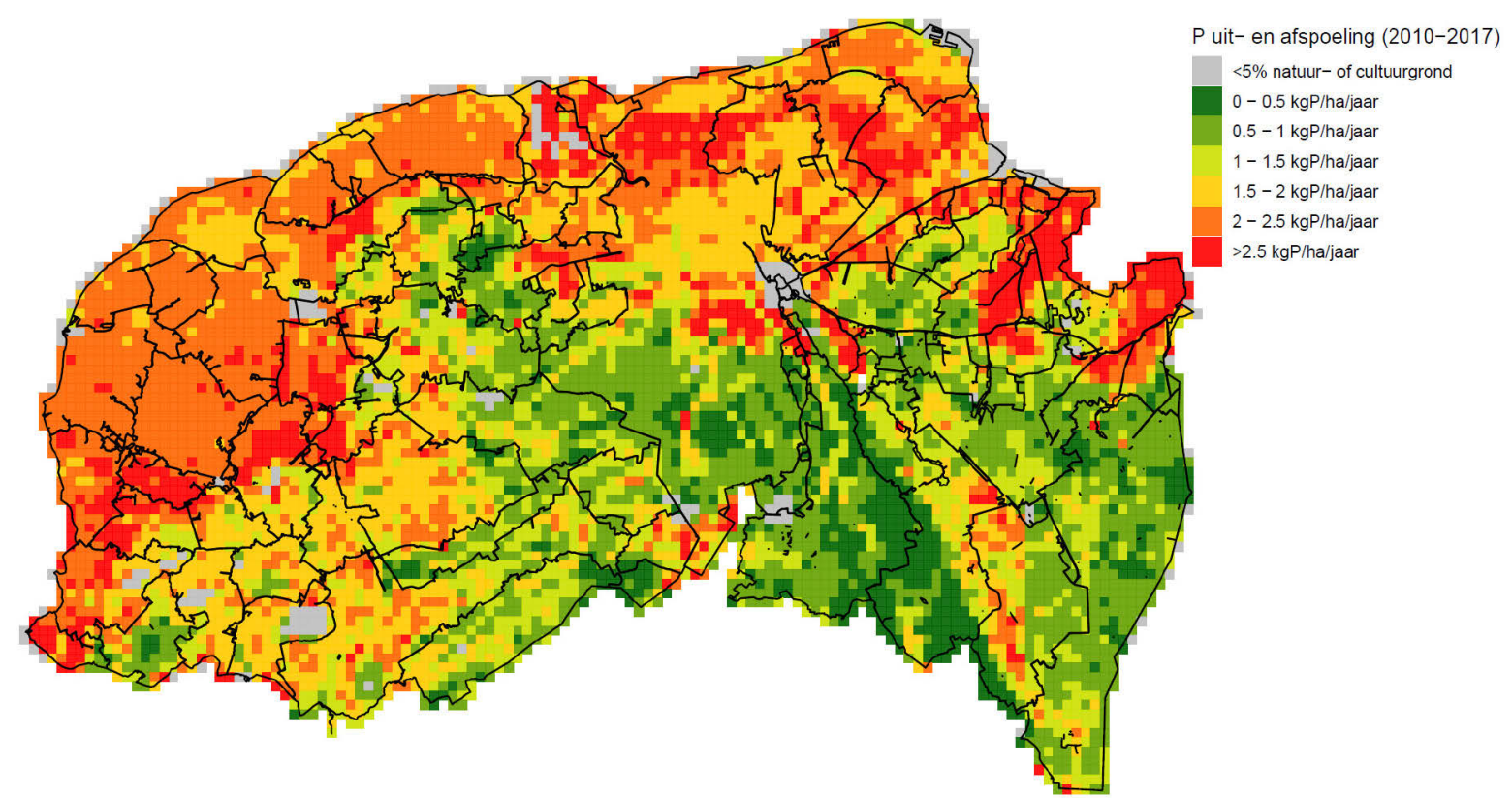

Figuur 3.8 Jaargemiddelde uit- en afspoeling van fosfor vanuit landbouw- en natuurgronden naar het oppervlaktewater over de periode 2010-2017. 
Oppervlakkige afstroming van fosfor is een belangrijke emissieroute. Enerzijds omdat oppervlakkige afstroming een aanzienlijk deel is van de totale af- en uitspoeling van fosfor. Anderzijds omdat er voor het verminderen van de uitspoeling van fosfor weinig effectieve handelingsperspectieven op het agrarisch perceel zijn (bronmaatregelen hebben weinig effect), terwijl er juist wel effectieve handelingsperspectieven zijn om de oppervlakkige afstroming te verminderen of af te vangen. Daarom kunnen de kaarten van Figuur 3.5 (risico's afstroming) en 3.6 (afspoeling fosfor) worden gebruikt om hotspots aan te wijzen voor het vinden van kansrijke maatregelen om de belasting met fosfor te verminderen. Voor stikstof kunnen bronmaatregelen (minder $\mathrm{N}$-overschot) wel effectief zijn om de uitspoeling te verminderen. Daarom is voor stikstof de kaart in Figuur 3.7 te gebruiken om hotspots aan te wijzen voor het vinden van kansrijke maatregelen om de uitspoeling met stikstof te verminderen.

Het tijdverloop van de uit- en afspoeling zoals berekend over de periode 2014-2017 is weergegeven in de grafieken van Figuur 3.9. Hierin is ook het verloop van de waterfluxen weergegeven. Uit deze grafieken komt duidelijk het seizoenspatroon naar voren dat de uit- en afspoeling in de zomermaanden beduidend lager is dan in de rest van het jaar. Dit hangt samen met het neerslagoverschot, waardoor in de zomermaanden weinig water vanuit de percelen naar de ontwateringsmiddelen wordt afgevoerd.

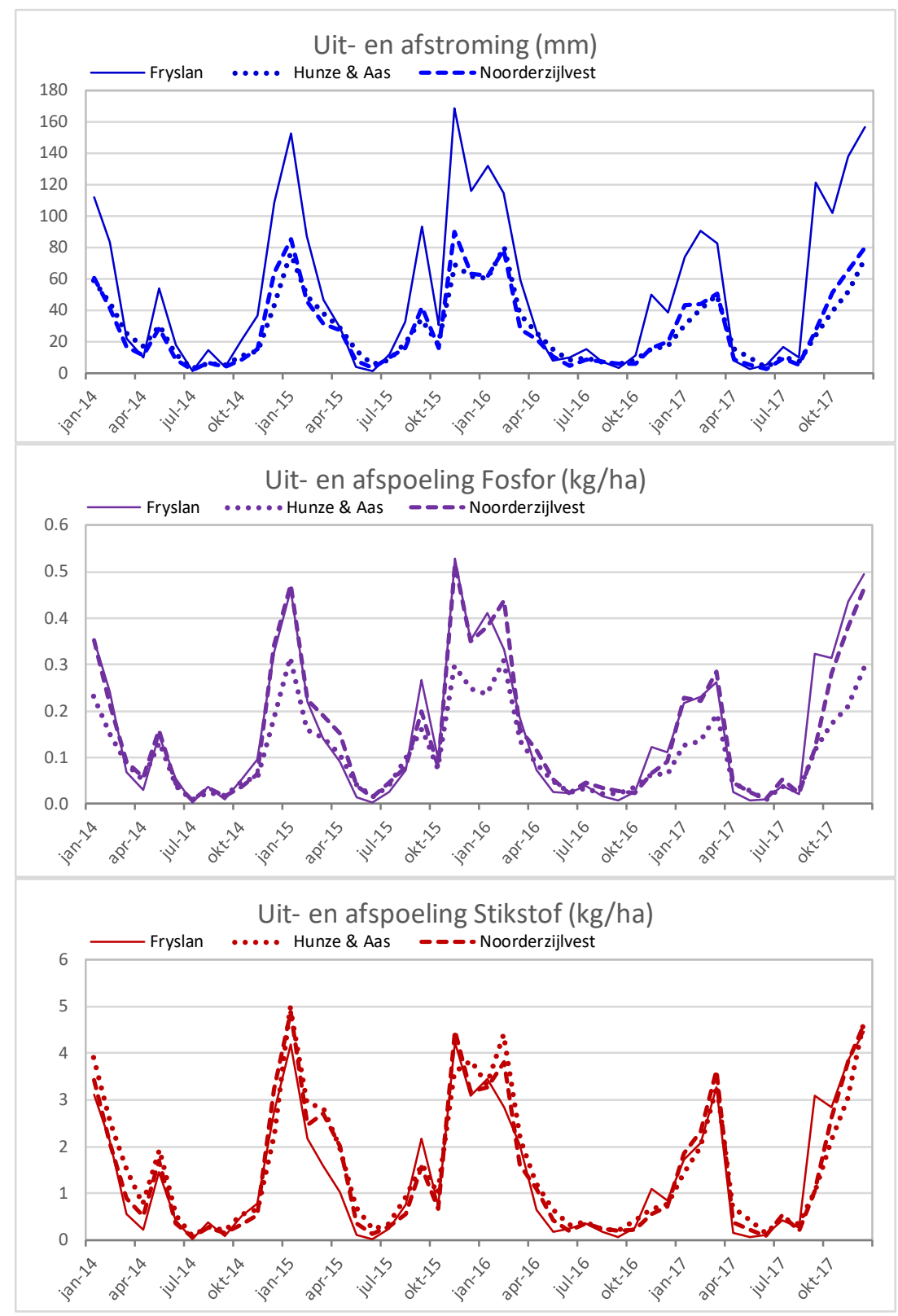

Figuur 3.9 De berekende uit- en afspoeling van fosfor en stikstof uit de landbouwbodems en de bijhorende waterfluxen (afstroming) over de periode 2014 tot en met 2017 per waterschapgebied. 
Bij de beoordeling van de uit- en afspoeling is het beleidsmatig relevant om te weten welk aandeel natuurbodems hierin hebben alsook om te weten welk aandeel actuele en historische bemesting heeft in de belasting vanuit landbouwbodems. Voor het modelinstrumentarium STONE is hiervoor een methode ontwikkeld waarmee per rekenplot globaal de bronnen achter de uit- en afspoeling worden onderscheiden in actuele en historische mestgiften en de overige bronnen die niet door bemesting worden gedreven, zijnde atmosferische depositie op het perceel, kwel die vanuit watervoerende lagen terechtkomt in het bodemprofiel, oppervlaktewater dat lokaal in een voorgaande tijdstap in het bodemprofiel is geïnfiltreerd en nalevering vanuit het bodemprofiel door uitloging en mineralisatie. Het hiermee berekende onderscheid voor de jaren 2014-2017 is per waterschapgebied weergegeven in Figuur 3.10.

Uit Figuur 3.10 komt naar voren dat de uit- en afspoeling vooral voorkomt door actuele bemesting en nalevering. Voor stikstof is het berekende aandeel van actuele bemesting het grootst (45-61\%), voor fosfor is dat nalevering (41-49\%). Het berekende aandeel van historische mestgiften is voor fosfor 10 à $13 \%$; voor stikstof is dat aandeel veel kleiner (ca. $3 \%$ ). Voor de natuurbodems is een bijdrage in de totale uit- en afspoeling berekend van 8 tot $14 \%$. Verschillen in de herkomst tussen het zomer- en winterhalfjaar zijn niet aan te geven, omdat de mestgiften, gewasgroei en bodembewerkingen doorwerken in opvolgende maanden (en jaren).

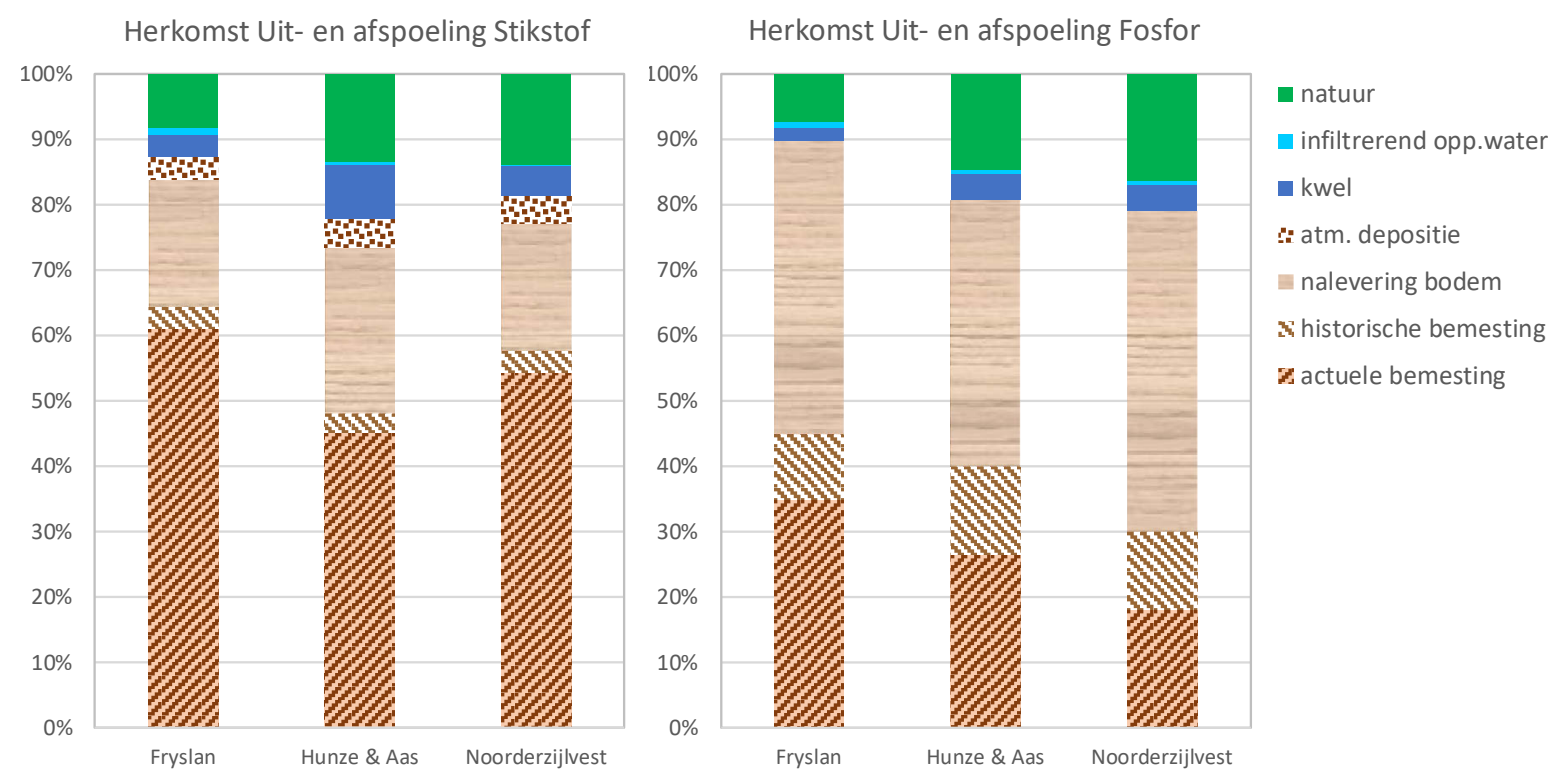

Figuur 3.10 Herkomst van de bronnen achter de uit- en afspoeling van stikstof (links) en fosfor (rechts), zoals berekend over de periode 2014-2017 (jaargemiddeld).

De absoluut berekende belasting van $\mathrm{N}$ en $\mathrm{P}$ die in de periode 2014-2017 in het zomer- en winterhalfjaar voorkomt, is weergegeven in Figuur 3.11. Hierin is, mede ten behoeve van de aansluitende oppervlaktewaterkwaliteit modellering (Boderie et al., 2021), onderscheid gemaakt in de vormen waarin volgens de modelberekeningen stikstof en fosfor uitspoelt. De berekende stikstofuit- en afspoeling in het zomerhalfjaar bedraagt circa $13 \mathrm{~kg} \mathrm{~N} / \mathrm{ha}$ (Fryslân en Noorderzijlvest) en $16 \mathrm{~kg} \mathrm{~N} / \mathrm{ha}$ (Hunze \& Aa's. In het winterhalfjaar is de uit- en afspoeling ongeveer viermaal zo groot (55-59 kg N/ha). Het aandeel van nitraat hierin is in het winterhalfjaar wat groter (42-60\%) dan in de zomer (33-47\%), omdat in de zomerperiode meer invloed is van toestromend ammoniumrijk grondwater.

De berekende fosforuit- en afspoeling in het zomerhalfjaar bedraagt circa 0,6 kg P/ha (Hunze \& Aa's en Noorderzijlvest) en $0,7 \mathrm{~kg} \mathrm{P} / \mathrm{ha}$ (Fryslân). In het winterhalfjaar is de uit- en afspoeling ongeveer driemaal zo groot in het gebied van Hunze \& Aa's $(1,8 \mathrm{~kg} \mathrm{P} / \mathrm{ha0})$ en viermaal zo groot in de andere gebieden ( $3 \mathrm{~kg} \mathrm{P} /$ ha in Fryslân en 2,4 in Noorderzijlvest). Ongeveer driekwart van deze uit- en afspoeling is in de vorm van fosfaat. 


\subsection{Aansluiting op waterkwaliteitsmodel SOBEK}

De rekenresultaten van de nieuwe STONE-berekeningen zijn per deelstroomgebied (57-tal) als input gebruikt in de waterkwaliteitsmodel SOBEK dat parallel aan de synthese door Deltares voor het studiegebied is ontwikkeld (Boderie et al., 2021). In dit model is het oppervlaktewatersysteem geschematiseerd in hoofdwatergangen en de hierop afwaterende deelstroomgebieden. De berekende effecten van de bufferzones zijn met dit SOBEK-model doorgerekend door de uit- en afspoeling van stikstof en fosfor voor ieder deelstroomgebied te vermenigvuldigen met het per deelstroomgebied berekende zuiveringspercentage.

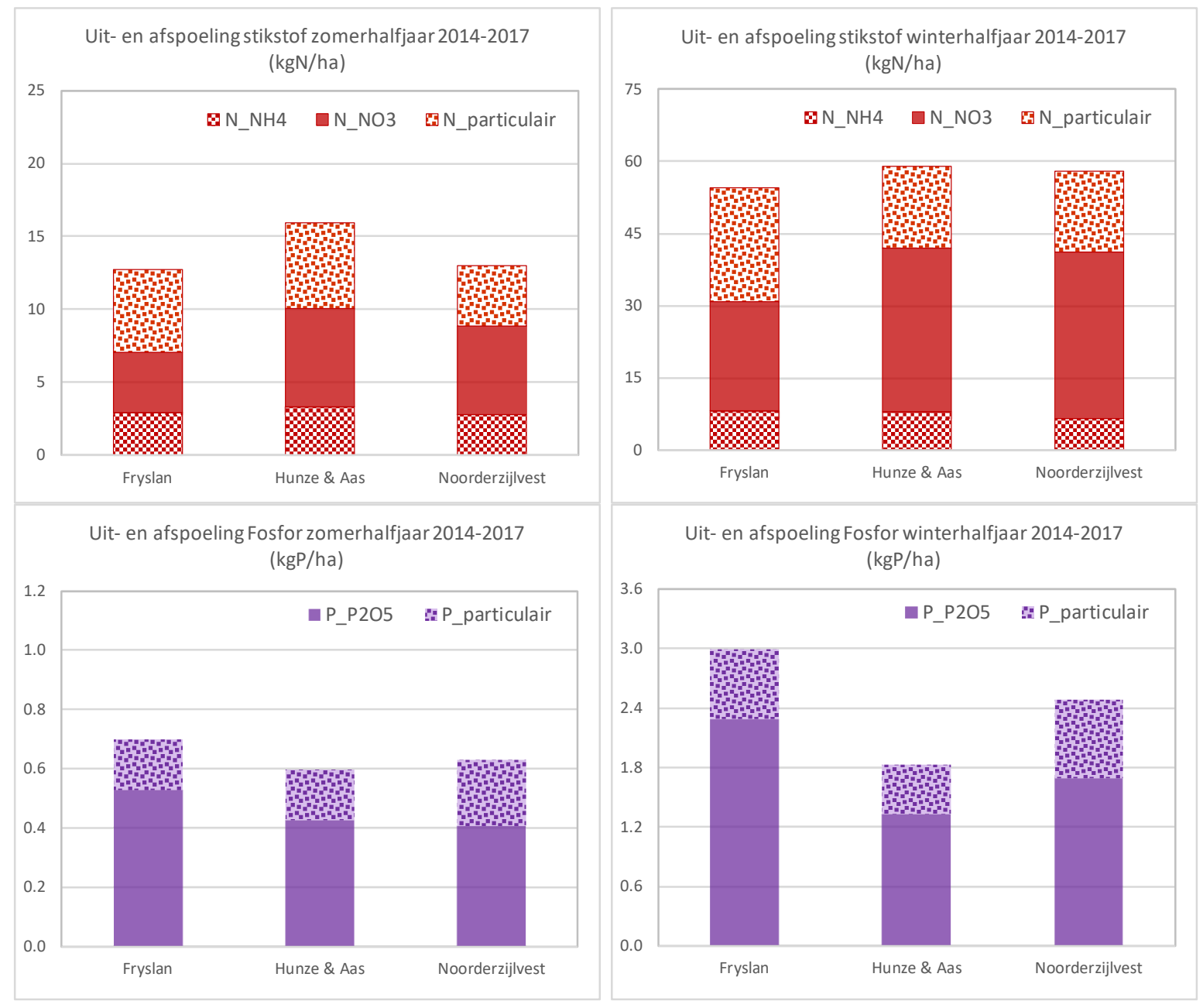

Figuur 3.11 Uit- en afspoeling stikstof (boven) en fosfor (onder) berekend voor het zomerhalfjaar (links) en het winterhalfjaar (rechts) over de periode 2014-2017. Ten behoeve van de aansluitende oppervlaktewaterkwaliteitsmodellering zijn de hoeveelheden voor stikstof uitgesplitst in ammonium $\left(\mathrm{NH}_{4}\right)$, nitraat $\left(\mathrm{NO}_{3}\right)$ en particulair gebonden stikstof en voor fosfor in opgeloste vorm (fosfaat) en particulair gebonden fosfor. 


\section{$4 \quad$ Effecten van bufferzones}

\subsection{Maatregelen landbouwgronden}

Om de KRW-doelen te realiseren, is een substantiële reductie van de huidige uit- en afspoeling van $\mathrm{N}$ en $\mathrm{P}$ uit landbouwgronden nodig (Groenendijk et al., 2016). De regionale spreiding van de opgave is groot, wat betekent dat de gewenste inzet van maatregelen verschilt per gebied. In de afgelopen jaren zijn er honderden agrarische maatregelen geïdentificeerd om de waterkwaliteit te verbeteren (Schoumans et al., 2012; Velthof et al., 2018; Verloop et al., 2018; Van Gerven et al., 2019). Deze maatregelen grijpen in op het nutriëntenoverschot (bron), de efficiëntie van bemesting (maatregelen bodemkwaliteit), de verliesroutes dan wel het ontvangende waterlichaam (Figuur 4.1).

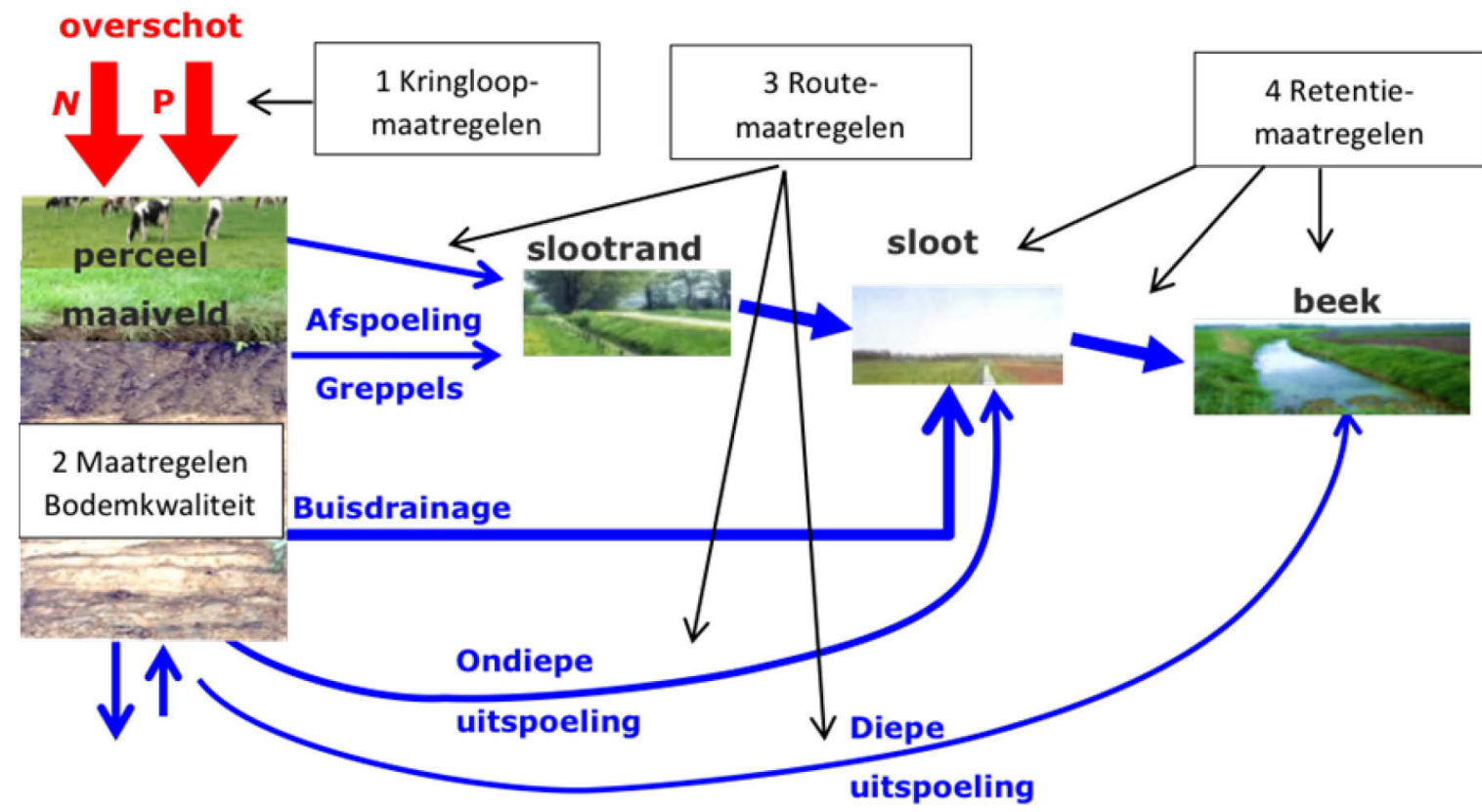

Figuur 4.1 Indeling van maatregelen voor het verlagen van de nutriëntenbelasting van het oppervlaktewater naar aangrijpingspunt: kringloop, bodem, route en retentie (Rozemeijer et al., 2016).

Het mestbeleid was er tot 2016 vooral op gericht om de aanvoer van nutriënten naar de bodem te verlagen (reductieoverschot). Dit gebeurde via gewasspecifieke gebruiksnormen voor stikstof, fosfaatnormen (afhankelijk van de bodemtoestand) en gebruiksvoorschriften wanneer mest wel of niet toegediend mag worden. In het laatste (zesde) Nitraatactieprogramma wordt meer dan voorheen aandacht besteed aan maatregelen die ingrijpen op de transportroutes richting het oppervlaktewater (routemaatregelen). Uit beleidsevaluaties blijkt dat deze aanvullende maatregelen essentieel zijn om de nutriëntenbelasting zodanig te verminderen dat dit de KRW-doelen voor de waterkwaliteit niet belemmert (Grinsven \& Bleeker, 2017). Sinds 2018 krijgt de inzet van de landbouw vooral vorm via het bovenwettelijke spoor binnen het Deltaplan Agrarisch Waterbeheer. Maatwerk staat daarbij centraal, omdat de belangrijkste bronnen en routes afhankelijk zijn van perceelspecifieke kenmerken als de nutriëntentoestand, het bouwplan, de aanwezigheid van drainage en de morfologie van het perceel. Ook de inzetbaarheid en effectiviteit van maatregelen variëren per perceel. 


\section{Bufferstroken}

In het onderzoek is er in overleg met de begeleidingscommissie voor gekozen om de effecten van bufferstroken te kwantificeren. Bufferstroken zijn niet-bemeste stroken op de overgang van perceel naar sloot, vaak met een natuurlijke begroeiing (zie Figuur 4.2). Bufferstroken hebben een positief effect op de terrestrische en aquatische biodiversiteit en zorgen er tevens voor dat er minder nutriënten vanuit het perceel naar het oppervlaktewater gaan. Dat laatste komt enerzijds doordat de bufferstrook niet bemest wordt en anderzijds doordat de bufferstrook een zuiverend effect heeft op het water en de stoffen die de bufferstrook doorstromen. Het gaat dan vooral om oppervlakkig en ondiep afstromend water.

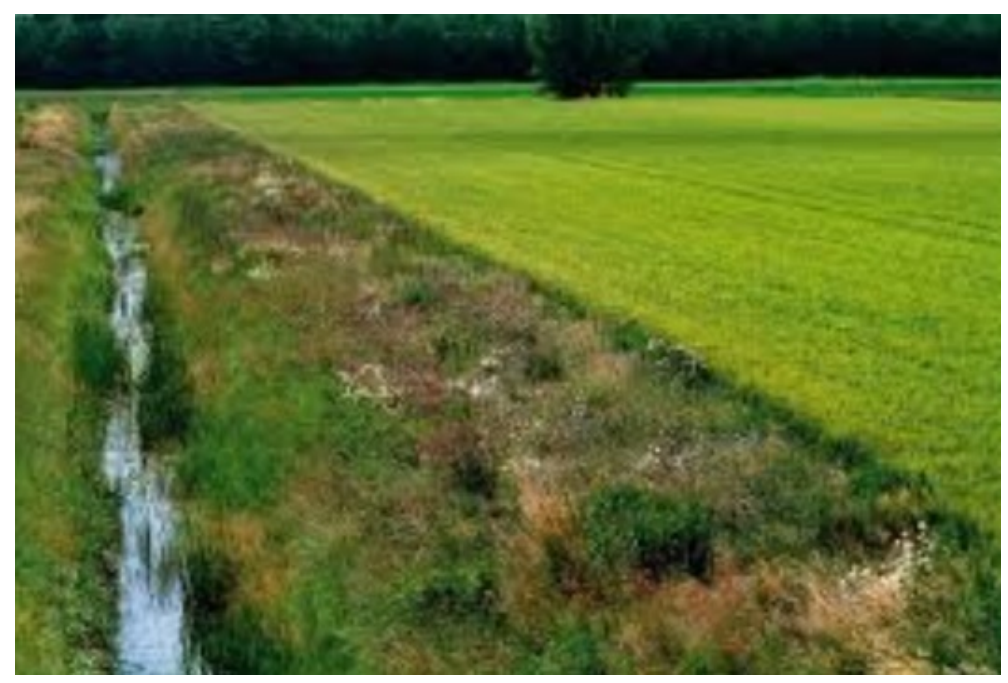

Figuur 4.2 Voorbeeld van een bufferstrook.

\subsection{Uitgangspunten en methodiek berekeningen bufferstroken}

\section{Uitgangspunten toepassingsgebied en breedte}

$\mathrm{Er}$ is al redelijk veel praktijkervaring en onderzoek gedaan naar het effect van bufferstroken, zowel in Nederland als daarbuiten. Met deze inzichten is door de WUR een methodiek ontwikkeld om het effect van bufferstroken op de af- en uitspoeling naar oppervlaktewater te kwantificeren (Groenendijk et al., 2021). Deze methodiek is toegepast in dit rapport. De methodiek kijkt eerst naar waar bufferstroken toepasbaar zijn. Bufferstroken worden zinvol geacht voor percelen:

- Met grasland, bouwland of overige open teelten (geen natuur);

- Groter dan $2500 \mathrm{~m}^{2}$ en met voldoende breedte, zodat het perceel nog steeds landbouwkundig gebruikt kan worden (bij een minimale bufferstrookbreedte van $2 \mathrm{~m}$ );

- Die voor minstens $10 \%$ aan waterlopen grenzen;

- Zonder buisdrainage of met minder dan $10 \%$ buisdrainage.

Met deze uitgangspunten leent ongeveer $40 \%$ van de landbouwpercelen in Nederland zich voor bufferstroken. Voor de breedte wordt uitgegaan van maximaal $5 \mathrm{~m}$. Deze breedte wordt verminderd tot een minimum van $2 \mathrm{~m}$ als het areaal van de strook meer dan $5 \%$ van het perceel inneemt. Voor natte graslanden wordt sowieso uitgegaan van $2 \mathrm{~m}$ als maximale breedte, omdat dit op die percelen vrijwel altijd al meer dan $5 \%$ van het perceel inneemt.

Lopende het onderzoek is discussie ontstaan over het uitgangspunt om bufferstroken in de methode niet toe te passen op percelen waar buisdrainage ligt. Uit die discussie is geconcludeerd dat het zinvol is om de methode daarop aan te passen door die percelen wel mee te nemen en daar een wat minder grote zuiverende werking van de bufferstrook te berekenen. Deze aanpassing kon niet binnen het onderhavige onderzoek worden uitgevoerd. 


\section{Rekenwijze zuiverende werking}

De zuiverende werking van een bufferstrook verschilt wat betreft effectiviteit voor stikstof en fosfor. Voor stikstof is het zuiveringspercentage van de bufferstrook ( $\mathrm{N}_{\mathrm{BS}}$ in \%) gerelateerd aan het oppervlaktepercentage van de bufferstrook ( $A_{B S}$ in \%) via:

$$
N_{B S}=2 * A_{B S} \times\left(\frac{\text { perceelomtrek }}{\text { bufferstrooklengte }}\right)^{0.5}
$$

waarbij $\mathrm{N}_{\mathrm{BS}}$ is afgekapt op maximaal 75\%. Een groter zuiveringspercentage wordt op basis van voorgaande onderzoeken naar bufferstroken niet als realistisch beschouwd en is in lijn met de aanname van het maximaal veronderstelde aandeel van de oppervlakkige P-afspoeling. De factor 2 in de formule representeert een bemestingseffect (omdat bufferstrook niet wordt bemest) en een onderscheppingseffect (en deel van het uit- en afspoelende stikstof wordt door de bufferstrook gezuiverd). Het zuiverend vermogen is gecorrigeerd voor de lengte aan bufferstrook t.o.v. de perceelsomtrek (tweede deel van formule), waarbij is aangenomen dat een kortere strook een hoger zuiverend vermogen heeft, omdat deze strook naar verhouding meer run-off-water te verstouwen krijgt. Het zo berekende zuiveringspercentage van de totale uit- en afspoeling varieert tussen de 0 en $75 \%$, en bedraagt $10 \%$ tot $20 \%$ voor de meeste percelen in Nederland. Deze getallen komen aardig overeen met experimentele resultaten, die een grote spreiding vertonen en gemiddeld rond de $15 \%$ uitkomen voor een bufferstrookbreedte van $5 \mathrm{~m}$. Zo geven Van der Welle en Decleer (2001) onder Belgische omstandigheden een stikstofzuiveringspercentage van $15 \%$ bij een bufferstrookbreedte van $5 \mathrm{~m}$. Noij et al. (2012) geven op basis van modelberekeningen een bandbreedte van 10-20\% voor een bufferstrookbreedte van $5 \mathrm{~m}$ onder Nederlandse omstandigheden.

Voor fosfaat wordt verondersteld dat een bufferstrook vooral effect heeft op het oppervlakkige transport via surface run-off. Surface run-off wordt beïnvloed door een aantal factoren, waaronder de ruwheid van het maaiveld, de grondsoort, teeltwijze, helling en omvang van het perceel. Aangenomen is dat de hoeveelheid fosfor die de bufferstrook zuivert $\left(P_{B S}\right.$, in $\mathrm{kg} \mathrm{ha}^{-1}$.jaar $\left.{ }^{-1}\right)$, afhangt van de hoeveelheid van surface run-off $\left(q_{\text {runoff }}\right.$ in $\mathrm{mm}$.jaar $\left.{ }^{-1}\right)$. Deze hoeveelheid bestaat uit Horton-flow $\left(q_{\text {Horton }}\right.$ in $\mathrm{mm}_{\text {.jaar }}{ }^{-1}$ ) en Dunne flow $\left(q_{\text {Dunne }}\right.$ in $\left.\mathrm{mm}_{\text {.jaar }}{ }^{-1}\right)$. Verder hangt het af van de P-concentratie in runoff-water ( $C_{\text {runoff }}$ in $\mathrm{mg} \mathrm{P/I}$ ) en het vermogen van de bufferstrook om fosfaat in run-off-water te zuiveren $\left(P_{\text {eff }}\right.$ als fractie $\left.[-]\right)$ :

$$
P_{B S}=\frac{1}{100} * c_{\text {runoff }} *\left(1.5 * P_{\text {eff }} * q_{\text {Horton }}+P_{\text {eff }} * q_{\text {Dunne }}\right)
$$

waarin:

$$
\begin{aligned}
& q_{\text {Horton }}=q_{\text {Horton, ref }} \times\left(\frac{24}{\text { afstand tot waterloop }}\right)^{0.5}\left(\frac{\text { helling }}{0.89}\right)^{0.5} \\
& P_{\text {eff }}=0.895\left(1-e^{-0.16 \times \text { bufferstrookbreedte }}\right) \times\left(\frac{\text { perceelomtrek }}{\text { bufferstrooklengte }}\right)^{0.5}
\end{aligned}
$$

waarbij de factor $1 / 100$ voortkomt uit conversie naar de juiste eenheden. 'Horton overland flow' ( $q_{\text {Horton }}$ ) ontstaat als grond dichtslaat. 'Dunne overland flow' $\left(q_{\text {Dunne }}\right.$ ) ontstaat als de onderliggende bodem verzadigd is. In vergelijking 4.2 is te zien aan de factor 1.5 dat het fosfaat in Horton-flow beter wordt gezuiverd dan het $\mathrm{P}$ in Dunne-flow. Dit is gedaan om te compenseren voor het zomereffect, wanneer de bufferstroken het meest begroeid zijn en daardoor de grootste zuiverende werking hebben. Omdat Horton-flow meestal optreedt in de zomer (bij hevige onweersbuien) en Dunne-flow meestal in de winter, is extra zuivering geïntroduceerd (factor 1.5) voor Horton-flow. De grootte van de run-off ( $q_{\text {Horton }}$ en $q_{\text {Dunne }}$ ) is op dezelfde manier berekend als eerder beschreven (sectie 3.4.1). Ditzelfde geldt voor de bepaling van de P-concentratie in het run-off-water ( $c_{\text {runoff }}$ ), aan de hand van de gemeten fosfaattoestand (Pw-getal) van de landbouwbodems in Noord-Nederland (paragraaf 3.4.1). Waar nodig is de afstromende P-vracht afgekapt, zodat deze per perceel nooit groter is dan $75 \%$ van de totale uit- en afspoeling zoals berekend met STONE (Wolf et al., 2003).

Als laatste stap is bepaald welk deel van de berekende afstromende P-vracht wordt afgevangen door de bufferstrook $\left(P_{\text {eff }}\right)$. Het eerste deel van de gehanteerde formule voor de zuiveringsfractie $P_{\text {eff }}$ volgt 
uit een meta-analyse naar de zuivering van bufferstroken door Zhang et al. (2010). Bufferstroken van $5 \mathrm{~m}$ breedte hebben volgens deze formule een zuiverend vermogen van ongeveer $50 \%$, stroken van $2 \mathrm{~m}$ breed zuiveren circa $25 \%$. Dit zuiverend vermogen is gecorrigeerd voor de lengte aan bufferstrook t.o.v. de perceelsomtrek (tweede deel van formule voor $P_{\text {eff }}$ ), waarbij is aangenomen dat een kortere strook een hoger zuiverend vermogen heeft, omdat deze strook naar verhouding meer run-off-water te verstouwen krijgt. Deze berekening houdt geen rekening met het hogere zuiverende vermogen van de bufferstrook in de zomer t.o.v. de winter. Daarom is $P_{\text {eff }}$ verhoogd met $50 \%$ voor water dat afspoelt via Horton-flow, omdat Horton-flow vaak in de zomer optreedt in tegenstelling tot Dunne-flow, die vooral in de winter plaatsvindt. $P_{\text {eff }}$ is in alle gevallen afgekapt op $75 \%$, zodat de zuiverende werking van de bufferstrook nooit groter is dan $75 \%$ van de totale uit- en afspoeling.

\subsection{Toepassingsgebied en breedte bufferstroken}

Met de uitgangspunten die in de voorgaande paragraaf zijn geformuleerd, zijn het toepassingsgebied en de breedte van de bufferstroken voor het gebied berekend zoals weergegeven in Tabel 4.1 en Figuur 4.3. Van alle landbouwpercelen in het beschouwde studiegebied is met die uitgangspunten ongeveer $40 \%$ geschikt voor de aanleg van bufferstroken. In het beheergebied van Fryslân ligt dit percentage duidelijk hoger (47\%) en in Noorderzijlvest lager (24\%). Met de aannames is een totale lengte aan bufferstroken berekend van $34.500 \mathrm{~km}$. De berekende breedte varieert hierbij van 2 tot circa $4 \mathrm{~m}$.

Tabel 4.1 Geschiktheid stroomgebieden voor bufferstroken. Zie Figuur 4.1 voor stroomgebiedsligging.

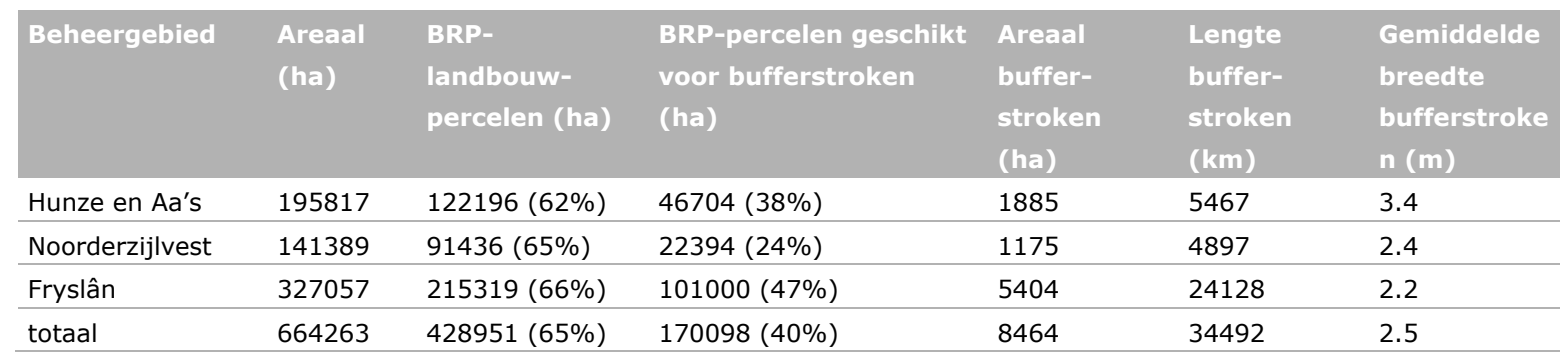

De geschiktheid voor bufferstroken kan sterk verschillen per deelgebied (zie Tabel 4.1, Figuur 4.3 en Figuur 4.4). De geschiktheid is relatief laag in de hogere zandgronden, omdat hier minder percelen grenzen aan water (zie Figuur 4.4 rechts). Voor percelen in dit gebied die wel grenzen aan water zijn vaak bredere bufferstroken mogelijk dan elders in het gebied. De klei- en veengebieden met dichte slootnetwerken lenen zich niet voor brede bufferstroken, omdat er dan nog maar weinig perceelareaal zou overblijven. Het aangenomen areaal bufferstroken in de noordelijke deelstroomgebieden is relatief laag. Dit komt vooral omdat hier veel percelen met buisdrainage liggen en dat in de gehanteerde methode geen bufferstroken zijn doorgerekend op percelen met buisdrainage. Bufferstroken kunnen op die percelen wel zinvol (effectief) zijn als daar ondanks de buisdrainage toch veel water oppervlakkig afstroomt. 


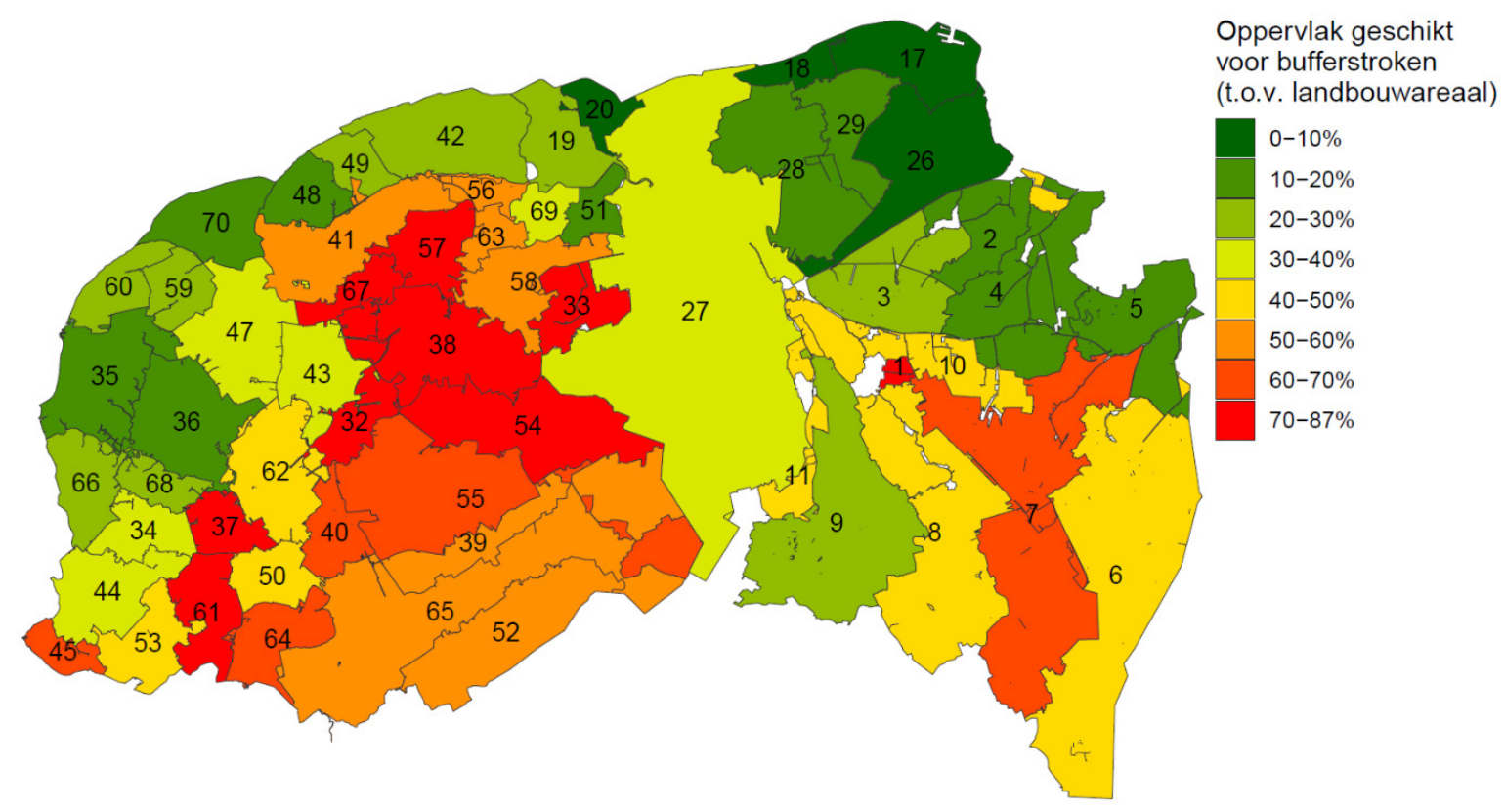

Figuur 4.3 Oppervlak van landbouwpercelen dat geschikt is voor bufferstroken, uitgedrukt als percentage van het totale landbouwareaal in het stroomgebied.
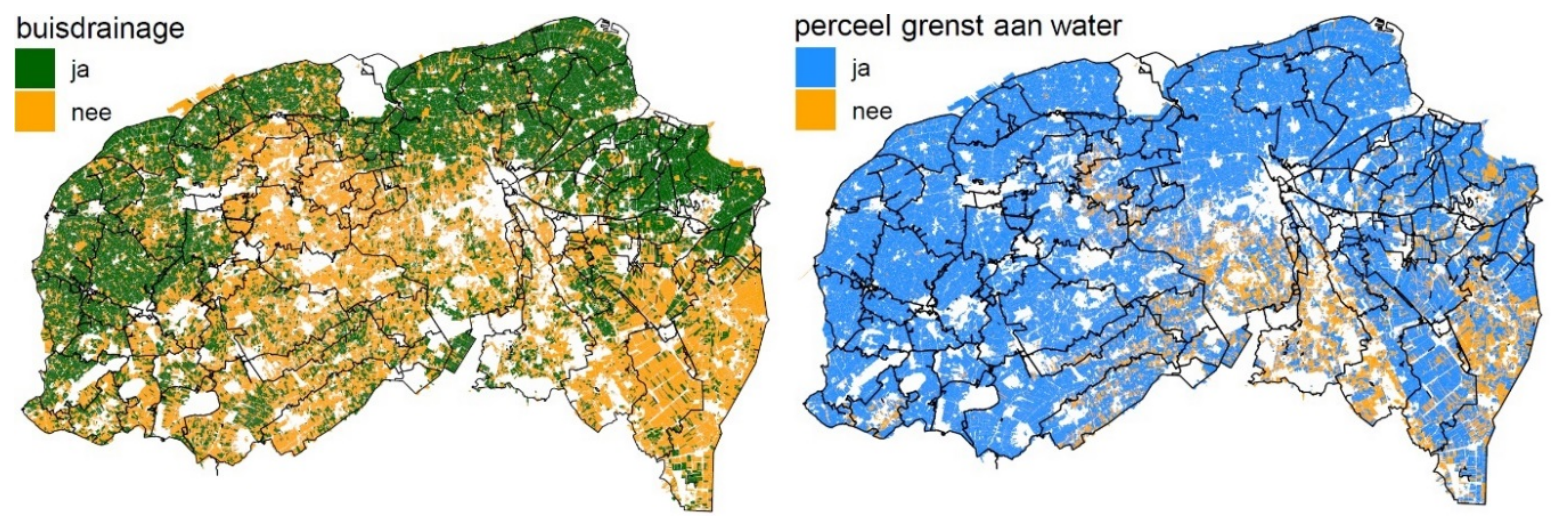

Figuur 4.4 Criteria die bepalend zijn voor de geschiktheid van bufferstroken, namelijk de afwezigheid van buisdrainage (links) en de aanwezigheid van waterlopen die grenzen aan het perceel (rechts).

\subsection{Zuiverende werking bufferstroken}

Over het hele gebied gemiddeld zou de aanleg van bufferstroken leiden tot een reductie op de totale uit- en afspoeling van naar schatting $5 \%$ voor stikstof en $4 \%$ voor fosfor (zie laatste regel van Tabel 4.2). Voor alleen de percelen met bufferstroken komt het gemiddelde zuiverende effect uit op $13 \%$ voor stikstof en $12 \%$ voor fosfor. Bij deze berekeningen is aangenomen dat de totale mestgift van het perceel afneemt naar rato van het bufferstrookareaal. De mestgebruiksruimte neemt dus af. Mocht de mestgebruiksruimte toch hetzelfde blijven, waardoor het bemeste deel van het perceel meer mest per hectare ontvangt, dan zal het zuiverende effect van de bufferstroken afnemen, vooral voor $\mathrm{N}$, waarvoor dit kan leiden tot maximaal een halvering van het effect.

Het zuiverende effect verschilt tussen de deelgebieden, voor fosfor meer dan voor stikstof (zie Tabel 4.2 en Figuur 4.5). Het totale zuiverende effect hangt af van het percentage landbouwgrond dat zich leent voor bufferstroken (Figuur 4.3). Voor de percelen met bufferstroken is het verschil in effectiviteit vooral te wijten aan het verschil in bufferstrookbreedte of -areaal (vooral voor stikstof geldt dat een bredere strook een groter zuiverend effect heeft) en de hoeveelheid nutriënten die de bufferstrook doorstroomt via oppervlakkige en ondiepe afstroom (vooral voor fosfor geldt: hoe groter de afspoelende vracht, hoe groter het zuiverende effect van de bufferstrook). 
Zoals aangegeven, is in de methode aangenomen dat percelen waar buisdrainage aanwezig is, geen bufferstrook wordt aangelegd. Voor (beleids)keuzes over stimulering van bufferzones wordt echter aanbevolen vooral te kijken naar gebieden (percelen) waar relatief grote risico's zijn voor oppervlakkige afstroming van fosfor. Deze risico's zijn weergegeven in Figuur 3.6.

Tabel 4.2 Reductiepercentages af- en uitspoeling door bufferstroken voor het totale landbouwgebied (kolom 4-5) en voor alleen het gebied dat geschikt is voor de aanleg van bufferstroken (kolom 6-7).

\begin{tabular}{|c|c|c|c|c|}
\hline \multirow[t]{2}{*}{$\begin{array}{l}\text { Beheersgebied } \\
\text { Waterschap }\end{array}$} & \multicolumn{2}{|c|}{$\begin{array}{l}\text { Reductie af- en uitspoeling } \\
\text { landbouwgebied door bufferstroken }\end{array}$} & \multicolumn{2}{|c|}{$\begin{array}{l}\text { Reductie af- en uitspoeling door bufferstroken } \\
\text { in het deel van het landbouwgebied dat } \\
\text { geschikt is voor bufferstroken }\end{array}$} \\
\hline & Stikstof ( $\%)$ & Fosfor $(\%)$ & Stikstof $(\%)$ & Fosfor ( $\%)$ \\
\hline Hunze en Aa's & $5 \%$ & $4 \%$ & $12 \%$ & $9 \%$ \\
\hline Noorderzijlvest & $3 \%$ & $3 \%$ & $13 \%$ & $15 \%$ \\
\hline Fryslân & $6 \%$ & $7 \%$ & $13 \%$ & $14 \%$ \\
\hline
\end{tabular}

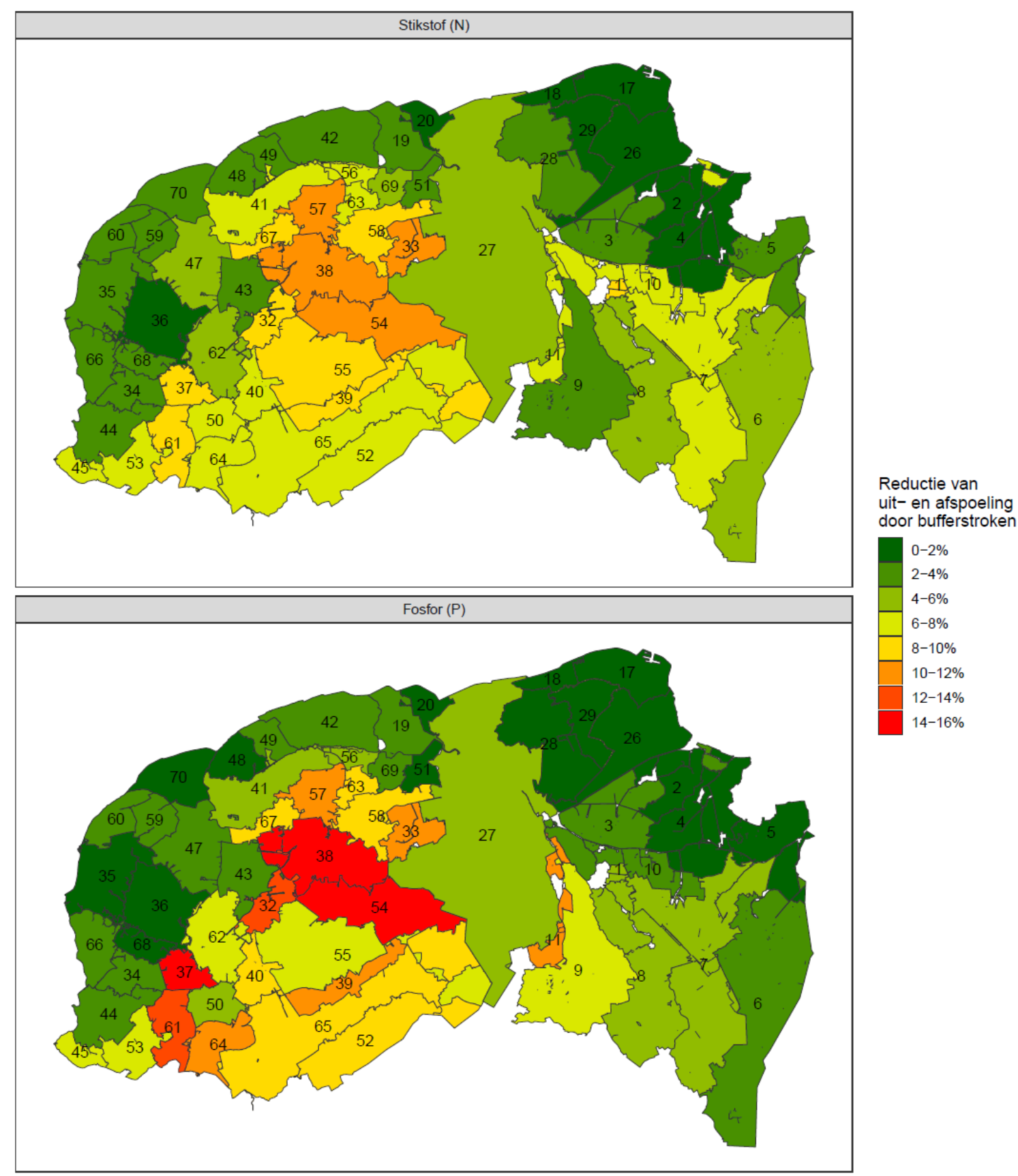

Figuur 4.5 Berekende effect van de aanleg van bufferstroken op de totale uit- en afspoeling vanuit landbouwgebied, uitgedrukt in een reductiepercentage voor stikstof (boven) en fosfor (beneden). Zie kolom 4 en 5 in Tabel 4.2. 
Ook is gekeken hoe de zuiverende werking van de bufferstroken afhangt van de bufferstrookbreedte. Deze breedte varieert tussen de 2 en $5 \mathrm{~m}$, al zijn verreweg de meeste bufferstroken $2 \mathrm{~m}$ breed (zie Figuur 4.6). De meeste percelen zijn namelijk natte graslanden, waarvoor de bufferstrookbreedte is gesteld op $2 \mathrm{~m}$ (zie methode). De drogere percelen hebben een bufferstrookbreedte van $5 \mathrm{~m}$, die eventueel wordt verminderd tot een minimum van $2 \mathrm{~m}$ als het areaal van de strook meer dan $5 \%$ van het perceel inneemt. Aan de zuiveringspercentages per bufferstrookbreedte-klasse is te zien dat de $\mathrm{N}$ zuivering afhangt van het percentage perceel dat de bufferstrook inneemt in combinatie met de bufferstrookbreedte (Tabel 4.3). Bij een gelijkblijvend percentage (van 5\%) neemt de $\mathrm{N}$-zuivering toe naarmate de bufferstrook breder is. De stroken van $5 \mathrm{~m}$ breed hebben echter het laagste zuiveringspercentage voor $\mathrm{N}$. Dit komt doordat de bufferstroken in deze (drogere) percelen gemiddeld geen $5 \%$, maar $3 \%$ van het perceel beslaan, waardoor de zuiverende werking kleiner is. Voor $P$ is er een minder duidelijk verband tussen het zuiveringspercentage en de bufferstrookbreedte. Dit komt doordat naast bufferstrookbreedte (hoe breder de strook, hoe groter de zuiverende werking) ook andere factoren van invloed zijn op de P-zuivering, zoals de P-aanvoer via oppervlakkige afstroom die sterk kan variëren binnen het gebied.

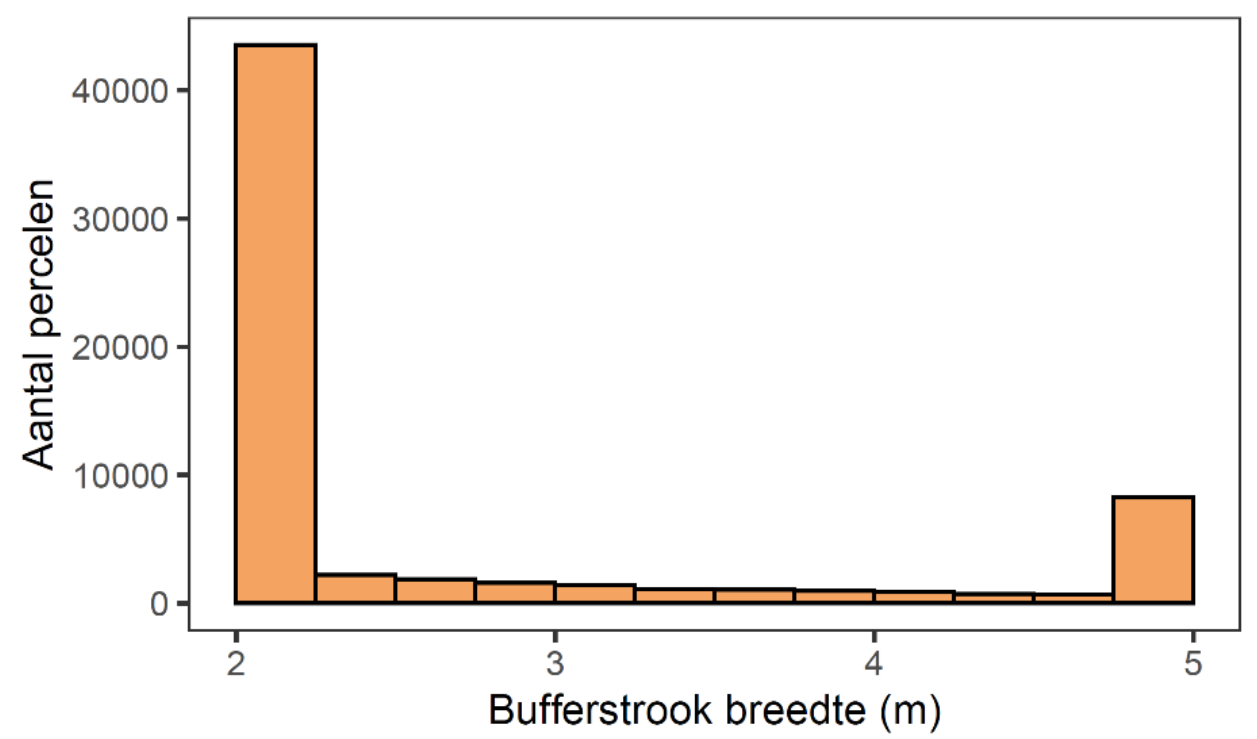

Figuur 4.6 Breedte van de bufferstroken in het studiegebied.

Tabel 4.3 Zuiverende werking van bufferstroken in het gehele studiegebied naar gelang de breedte van de bufferstrook.

\begin{tabular}{|c|c|c|c|c|c|}
\hline \multirow[t]{2}{*}{$\begin{array}{l}\text { Bufferstrook- } \\
\text { breedte }(\mathrm{m})\end{array}$} & \multirow[t]{2}{*}{$\begin{array}{l}\text { Totale lengte } \\
(\mathrm{km})\end{array}$} & \multirow[t]{2}{*}{ Aantal percelen } & \multirow[t]{2}{*}{$\begin{array}{l}\text { Bufferstrook- } \\
\text { areaal (ha) }\end{array}$} & \multicolumn{2}{|c|}{$\begin{array}{l}\text { Reductie van uit- en afspoeling door } \\
\text { bufferstroken }(\%)\end{array}$} \\
\hline & & & & Stikstof & Fosfor \\
\hline $2-3 m$ & $4609(13 \%)$ & $8531(13 \%)$ & $4771(5 \%)$ & 13.1 & 12.2 \\
\hline $3-4 m$ & $2334(7 \%)$ & $4591(7 \%)$ & $811(5 \%)$ & 13.4 & 11.8 \\
\hline $5 \mathrm{~m}$ & $2245(7 \%)$ & $7648(12 \%)$ & $1122(3 \%)$ & 10.9 & 12.8 \\
\hline
\end{tabular}




\section{Conclusies en aanbevelingen}

\subsection{Conclusies}

Voor het studiegebied zijn in het recente verleden met verschillende methodes onderzoeken uitgevoerd die inzicht geven in de uit- en afspoeling van stikstof en fosfor uit landbouw- en natuurbodems en de factoren die dit bepalen. In toenemende mate is informatie beschikbaar op perceelniveau die medebepalend is voor de uit- en afspoeling uit landbouw en natuurbodems. De onderzoeken die uitgingen van statistische benaderingen maakten gebruik van meetgegevens van de bovenste bodem $(10-25 \mathrm{~cm}$ ) en andere databronnen en deze zijn complementair aan de procesmatige modelonderzoeken. Die complementariteit zit in zowel het schaalniveau als in de toekenning van gemeten concentraties aan emissiebronnen.

Uit de studies die uitgaan van statistische benaderingen volgen gebiedskenmerken die in het studiegebied sturend zijn voor de uit- en afspoeling en de concentraties in regionale oppervlaktewateren. Op basis hiervan kan lokaal inzicht worden gegeven in de invloed van nutriëntgehaltes in de bodem, de bemesting en bodemkwaliteit op de variatie in $\mathrm{N}$ - en P-concentraties in het oppervlaktewater. Kennis van het bodem- en watersysteem is hierbij cruciaal om onderscheid te maken tussen causaliteit en correlatie. De mechanistische modellering met STONE biedt onderbouwd inzicht in de relatie tussen de historische en actuele belasting van de bodem, de bodembronnen, geohydrologie en het niveau van de uit- en afspoeling. Door de focus op mechanistische processen kan gericht inzicht worden gegeven in de bijdrage van verschillende bronnen en emissieroutes. Wel is het ruimtelijke schaalniveau waarop de modellen zijn gevalideerd van belang voor het leveren van maatwerk op lokaal niveau. Dit biedt potentie in de koppeling van de gebruikte brondata, de statistische modellen en het STONE-instrumentarium. Idealiter zou door de koppeling van beide benaderingen op perceelniveau inzicht geboden kunnen worden in de daadwerkelijke risico's van de uit- en afspoeling van N en P. De huidige beschikbare meetgegevens en modelonzekerheden zorgen er op dit moment (anno 2021) echter voor dat dit inzicht alleen op een grover ruimtelijk detailniveau geboden kan worden.

Enkele aandachtspunten die in die studies naar voren zijn gekomen om procesmatig modelonderzoek te verbeteren en verfijnen, zijn verwerkt in de herberekening van de uit- en afspoeling met SWAPAnimo rekenplots van het modelinstrumentarium STONE. Dit betreft de P-toestand van de ondiepe bodem (bovenste 10 en $25 \mathrm{~cm}$ ), hetgeen is verwerkt in berekening van de oppervlakkige afspoeling. Ook is gewerkt met verbeterde inschattingen van de concentraties van stikstof en fosfor in kwelwater, hetgeen verwerkt is in de berekende uitspoeling. De nieuwe berekeningen geven ruimtelijk inzicht in de 'hotspots', waar de grootste risico's zijn voor relatief hoge uit- en afspoeling van stikstof en waar de grootste risico's zijn voor oppervlakkige afspoeling van fosfor.

Om de uit- en afspoeling te verminderen, kunnen droge bufferzones worden ingezet. De modelberekeningen die voor de onderhavige studie zijn uitgevoerd, geven aan dat hiermee de uit- en afspoeling voor stikstof tot maximaal $15 \%$ afnemen en voor fosfor tot $20 \%$. Per deelstroomgebied kan dit sterk verschillen, enerzijds door de verschillen in de perceelskenmerken en anderzijds door de aannames dat percelen wel/niet geschikt zijn voor aanleg van een bufferstrook. In de deelstroomgebieden waar is aangenomen dat het merendeel $(>50 \%$ ) van de percelen zich leent voor aanleg van een bufferstrook, is berekend dat daar de uit- en afspoeling van stikstof afneemt van 6 tot $11 \%$ en van fosfor van 4 tot $15 \%$. In de methode is aangenomen dat percelen waar buisdrainage aanwezig er geen bufferstrook wordt aangelegd. Als ook voor die percelen het effect van een bufferstrook wordt berekend, zal ook daar de uit- en afspoeling afnemen, maar zal het effect minder groot zijn in vergelijking met percelen waar geen buisdrainage aanwezig is. Voor (beleids)keuzes over stimulering van bufferzones wordt aanbevolen vooral te kijken in gebieden (percelen) waar relatief grote risico's zijn voor oppervlakkige afstroming van fosfor. Deze risico's zijn weergegeven in Figuur 3.6. 


\subsection{Aanbevelingen voor vervolgstudies}

De voorliggende studie beschrijft en integreert de verschillende studies die in de afgelopen jaren zijn uitgevoerd om inzicht te krijgen in de uit- en afspoeling van stikstof en fosfor richting het oppervlaktewater. Op basis hiervan zien we kansen en mogelijkheden voor:

- Een sterkere eenduidigheid rond berekeningen van de uit- en afspoeling landbouw- en natuurgronden, bronnenanalyse en de hieruit af te leiden KRW-opgave voor nutriënten. Er is een grote variatie in classificaties, terminologie, gebruikte jaren, meetpunten en watersystemen. Het is aan te bevelen om dit verder te uniformeren en te standaardiseren.

- Een verdere ontwikkeling en koppeling van zowel de statistische als de mechanistische aanpak om zo de kracht van beide aanpakken te integreren en betrouwbare voorspellingen te genereren van de $\mathrm{N}$ - en P-uitspoeling op zowel regionaal als lokaal niveau.

- Een verdere verbetering van de meetbasis rond de geschatte $\mathrm{N}$ - en $\mathrm{P}$-aanvoer vanuit grondwater. Dit behelst onzes inziens een uitbreiding van het huidige monitoringsnet van de grondwaterkwaliteit om hiermee beter ruimtelijk inzicht te geven in de concentraties van fosfor en stikstof in het grondwater, die representatief zijn voor de invloed van kwel vanuit watervoerende lagen naar het ondiepe bodemprofiel en detaildrainage.

- Meer inzicht over het transport van fosfaat over het bodemprofiel. Dit houdt concreet in dat bodemkwaliteitsmetingen niet worden beperkt tot de bovenste toplaag (10-25 cm), maar ook dieper in de bodemprofiel (tot ca. $1 \mathrm{~m}-\mathrm{mv}$ ), met name om beter inzicht te krijgen in het verloop van de Pgehalten vanaf de wortelzone tot aan de freatische grondwaterstand (GLG).

Het gedrag van stikstof en fosfor gedurende het transport door het oppervlaktewater wordt sterk beïnvloed door de kenmerken en het beheer van de watergangen. Om met name beter inzicht te krijgen in de retentie die optreedt in de detailontwatering en in de meren en grote plassen die in verbinding staan met het boezemstelsel, zijn hoogfrequente metingen van zowel debieten als concentraties op belangrijke uitwisselpunten noodzakelijk om modellering van de nutriëntenbelasting en hieraan gekoppelde oppervlaktewaterkwaliteit te kunnen valideren. De indruk vanuit bestaande studies is dat de huidige monitoring van het oppervlaktewater hier nog weinig op is toegespitst.

Voor het inschatten van de potentie van bufferzones wordt aanbevolen de hier toegepaste rekenmethode aan te passen door bufferzones ook mee te nemen op percelen waar buisdrainage ligt.

\subsection{Aanbevelingen voor maatregelen}

\subsubsection{Handvatten voor haalbaarheid KRW-doelen}

Zoals eerder beschreven, is schoon en gezond grond- en oppervlaktewater een belangrijk onderdeel van een gezonde leefomgeving. Hoewel de waterkwaliteit de afgelopen decennia is verbeterd, zijn er nog steeds belangrijke opgaven omdat de verbetering van de fysisch-chemische waterkwaliteit de laatste jaren stagneert, met als resultante een mogelijke verslechtering van de ecologische waterkwaliteit.

In het rapport 'Nutriënten op hun plek. Arrangementen van waarde voor voedselproductie, bodem en water' (Westerhof et al., 2016) onderscheiden de auteurs vier strategieën om de N- en P-belasting vanuit de landbouw naar het oppervlaktewater te verlagen:

1. Inzet van maatregelen die onderdeel zijn van de Goede Landbouw Praktijk (GLP);

2. Inzet van een verbeterde GLP;

3. Inzet van maatregelen die de huidige praktijk verder extensiveren;

4. Het verlaten van de hoofdfunctie landbouw.

Naast deze strategieën, die gericht zijn op de landbouw, zijn ook maatregelen nodig voor een betere inrichting van het watersysteem om de ecologische randvoorwaarden te optimaliseren (voldoende licht, voldoende zuurstof, voldoende diepte etc.), maatregelen ter vermindering van N- en P-belasting van niet-landbouwbronnen, zoals effluentlozingen van rioolwaterzuiveringen (rwzi's), industriële 
lozingen en riool-overstorten en maatregelen waarmee gebiedsvreemd water dat wordt ingelaten of toestroomt vanuit andere deelstroomgebieden of het buitenland schoner wordt.

De ecologische sleutelfactoren voor de ontwikkeling van een gewenste ecologische toestand varieert per waterlichaam, waardoor de opgave per waterlichaam ook anders is. Dit vraagt maatwerk, waarbij de vermindering van de diffuse belasting vanuit bodems een van de grootste uitdagingen is, omdat er deels sprake is van een historische erfenis die niet op korte termijn met het huidige agrarisch management op te lossen is. Voor de hierboven genoemde vier strategieën is maatwerk essentieel, waarbij de KRW-doelen voor stikstof binnen handbereik liggen (Groenendijk et al., 2016; Ros et al., 2018c). De opgave voor fosfor is met de bestaande maatregelen echter niet te realiseren in alle gebieden (Grinsven \& Bleeker, 2017; Groenendijk et al., 2016) en vraagt inzet van extra maatregelen die ingrijpen op de transportroute naar, dan wel de retentie in het waterlichaam (strategie 3). De huidige focus van veel projecten binnen het DAW ligt juist vaak op de implementatie van een GLP. Dit betekent ook dat de belasting van het oppervlaktewater met $P$ daardoor weinig tot niet vermindert. In gebieden met een grote $\mathrm{N}$ - en $\mathrm{P}$-opgave zullen daarom maatregelen nodig zijn vanuit de derde of mogelijk zelfs vierde strategie.

Op basis van beschikbare kennis en inzichten is het aan te bevelen om de GLP (strategie 1) breed uit te rollen, omdat dit bijdraagt aan het sluiten van kringlopen, meerwaarde biedt voor de agrariër en positief bijdraagt aan lagere emissies naar het oppervlaktewater. Voor gebieden met een grotere opgave voor $\mathrm{N}$ en $\mathrm{P}$ is het aan te bevelen om aan de slag te gaan met maatregelpakketten die naar verwachting het effectiefst zijn voor vermindering van de nutriëntenverliezen (strategie 2-3) en hierop te monitoren. Hiervoor kan gebruik worden gemaakt van de verzamelde kennis uit de diverse studies die in Noord-Nederland zijn uitgevoerd en in dit rapport wordt samengevat. Belangrijkste les is dat in de zoektocht naar maatwerkoplossingen niet alleen gefocust moet worden op het agrarisch landgebruik (wat gebeurt er op een perceel), maar gekeken moet worden naar het gehele bodemwatersysteem, inclusief het beheer van sloot(randen). Instrumenten zoals de Maatregel-Op-De-Kaart, de BedrijfsWaterWijzer en het BedrijfsBodemWaterPlan (Ros et al., 2020a) kunnen hierbij van grote waarde zijn, omdat daarin de complexiteit van gebiedsopgaves, perceelskenmerken en belangrijkste routes van $\mathrm{N}$ en $\mathrm{P}$ worden verwerkt tot eenvoudig maatwerk per perceel en per bedrijf.

Op basis van expertkennis is geconcludeerd dat met combinaties van maatregelen de $\mathrm{N}$ - en $\mathrm{P}$ belasting van het oppervlaktewater substantieel kan worden verlaagd (Groenendijk et al., 2016; Rozemeijer et al., 2016). De toepassing, effectiviteit, de kosteneffectiviteit en termijn waarop effecten op de waterkwaliteit zichtbaar zijn, zijn sterk afhankelijk van regionale en zelfs lokale omstandigheden. ${ }^{5}$ De keuze voor de juiste maatregelen op de juiste plek vereist inzicht in de belangrijkste bronnen en routes van stikstof en fosfaat naar het oppervlaktewater én de stuurbaarheid ervan. Dit is relevant voor zowel de technische implementatie (waar zijn welke maatregelen zinvol) als de sociale motivatie (maatregelen moeten ook uitgevoerd worden) en het noodzakelijke instrumentarium om veranderingen in beweging te brengen. De modelresultaten zoals beschreven in deze rapportage onderbouwen dit inzicht en illustreren deze aanpak voor de potentiële effectiviteit en inzetbaarheid van bufferzones.

De belasting vanuit rwzi's is relatief eenvoudig stuurbaar, maar technische aanpassingen voor een schoner effluent vergen in het algemeen een forse investering. Het afwegen van zulke aanpassingen en investeringen vraagt om interne afstemming binnen de waterschappen om bestaande uitgangspunten van waterzuivering (die stuurt op concentraties) te combineren met ecologische doelen en daarvan af te leiden doelen om de nutriëntenbelasting te verlagen. Vermindering van de diffuse belasting vanuit de bodem is veel lastiger te realiseren, in het bijzonder voor fosfaat.

\footnotetext{
5 Uit enquêtes en workshops met experts blijken de inschattingen over de effectiviteit van maatregelen sterk uiteen te lopen. Het is onmogelijk maatregelen te selecteren die voor heel Nederland en voor elk bedrijf haalbaar en kostenefficiënt zijn. Het hoogst haalbare is een eenduidige procedure om per bedrijf maatregelen te selecteren en ontwerpen, rekening houdend met de lokale omstandigheden en de bedrijfsvoering conform de systematiek van MOK of BBWP. Een knelpunt bij de huidige bestuurlijk geaccordeerde lijst van bovenwettelijke maatregelen voor schoner oppervlaktewater is dat voor veel maatregelen op deze lijst nog niet bekend is hoe effectief ze zijn onder specifieke omstandigheden.
} 


\subsubsection{Handvatten voor ondersteunen DAW-spoor}

In 2013 is het Deltaplan Agrarisch Waterbeheer van start gegaan om een bijdrage te leveren aan de wateropgaven in Nederland. Heel concreet zijn daarbij de volgende doelen geformuleerd:

1. Het bereiken van een betere waterkwaliteit (oplossen van alle knelpunten in 2027);

2. Zorgen voor voldoende water (optimale waterhuishouding en spaarzaam watergebruik);

3. Koersen op hogere productie en efficiënt ruimtegebruik.

Voor het realiseren van deze doelstellingen is de afgelopen jaren samengewerkt tussen het agrarisch bedrijfsleven en waterbeheerders. Vanuit het DAW worden agrarisch ondernemers gestimuleerd en gefaciliteerd om met een water- en bodemgerichte bedrijfsvoering te werken aan duurzame oplossingen voor de wateropgaven. In beleidsnotities van het ministerie van LNV wordt onderkend dat kennis en innovatie cruciaal zijn in het transitieproces naar Kringlooplandbouw, maar ook dat dit sturing vanuit de overheid nodig heeft. Binnen DAW worden drie thema's onderscheiden waarin kennisdeling aan de orde komt: 1) de ontwikkeling van nieuwe kennis dan wel het beschikbaar maken van bestaande kennis, 2) het delen van kennis met partijen die betrokken zijn bij de uitrol van het DAW en 3) de implementatie van deze kennis op het boerenbedrijf.

In 2020 en 2021 zijn in het kader van het DAW gebiedsplannen gemaakt waarin de opgaves en het handelingsperspectief voor maatregelen concreet zijn gemaakt op het niveau van

(deel)stroomgebieden. In dat proces is regelmatig voortgebouwd op de resultaten van de in deze rapportage beschreven studies. De verschillende gebiedspartijen staan voor de komende jaren voor de uitdaging om deze doelen en maatregelen te vertalen in maatwerk per perceel en per bedrijf. Het is aan te bevelen om hierbij gebruik te (blijven) maken van de inzichten zoals die in deze studie zijn beschreven. Ook is het aan te bevelen om meer aandacht te geven aan het in beeld brengen van de effectiviteit van maatregelen. Omdat het DAW breder is dan alleen de kwaliteit van grond- en oppervlaktewater, komen hier ook aspecten rond de integraliteit van bodembeheer en DAWmaatregelen aan de orde. De eerdergenoemde instrumenten kunnen dit proces verder faciliteren (Ros et al., 2020ab).

\subsubsection{Relaties met overige beleidsthema's}

Er komt in het mestbeleid, bodembeleid, het agrarisch natuurbeleid alsook binnen grondwaterbeschermingsgebieden meer en meer aandacht voor maatwerk. Alleen via dit maatwerk is het mogelijk om de uiteenlopende doelen en beleidsopgaves te vertalen in maatregelen waarmee de agrarische sector bij kan dragen aan de realisatie van deze doelen. Deze ontwikkeling wordt bijvoorbeeld zichtbaar bij de invulling van het nieuwe GLB, het Deltaplan Agrarisch Waterbeheer, het (grond)water- en bodembeheer in de provincie Brabant, het Agrarisch Natuur en Landschapsbeheer en het pachtbeleid. De aanwezige opgaves die concreet moeten worden gemaakt per gebied liggen niet per se in lijn met een duurzame landbouwbodem met minimale verliezen naar grond- en oppervlaktewater. Denk bijvoorbeeld aan de opgave om substantiële hoeveelheden koolstof op te slaan in de Nederlandse bodem (voor het klimaat), de opgave om lokale organische reststromen te hergebruiken op het agrarisch bedrijf (voor de circulaire economie), de teelt van biobrandstoffen (voor het klimaat) en het verlate maaien of inunderen van percelen om weidevogels in het voorjaar een plek te geven om te foerageren of te nestelen (voor natuurbeheer). In al deze opgaven speelt de bodem een rol en bestaat er een risico dat maatregelen die positief uitwerken voor klimaat, biodiversiteit of circulaire economie, een negatieve invloed hebben op de $\mathrm{N}$ - en P-belasting naar het oppervlaktewater.

In de praktijk heeft de complexiteit van opgaven tot gevolg dat er knelpunten ontstaan op het terrein van landbouwkundige productie of duurzaamheid. Veel maatregelen hebben namelijk een direct of indirect negatief effect op het landbouwkundig areaal dan wel op het opbrengend vermogen van de bodem. Of maatregelen zorgen voor een toename in uit- en afspoeling van nutriënten, zoals vernatting of hoge toelaatbare P-giften. Integraliteit en maatwerk zijn twee cruciale begrippen die het mogelijk kunnen maken om op elke plek de juiste dingen te doen en trade-offs te voorkomen. Dit wordt concreet uitgewerkt in het concept van de KansenKaart (Verhoeven \& Ros, 2018ab): laat elke ondernemer op basis van zijn eigen bedrijf kijken aan welke opgaven hij/zij kan bijdragen, maak deze bijdrage inzichtelijk en ontwikkel nieuwe verdienmodellen om deze bijdrage te belonen. 
Wat betekent dit concreet voor de kwaliteit van grond- en oppervlaktewater in relatie tot de landbouwbodem? Op dit snijvlak zijn zowel synergie als trade-offs mogelijk. Veel maatregelen die positief zijn voor de bescherming van grondwaterkwantiteit en kwaliteit kunnen ook positief bijdragen aan de kwaliteit van de landbouwbodem. Denk bijvoorbeeld aan het voorkomen van afspoeling door beter bodembeheer (zorgt voor netto meer infiltratie en minder afspoeling), de teelt van vanggewassen of diep wortelende gewassen (vermindert grondwateraanvulling, maar verlaagt ook nitraatuitspoeling), een uitgekiende bemesting waarmee gestuurd wordt op een bemesting op het juiste moment, met de juiste meststof, op de juiste plek en met de juiste gift (verhoogt de bodemkwaliteit en verlaagt nitraatuitspoeling). Op basis van de specifieke kenmerken van percelen, zoals dat bijvoorbeeld vorm krijgt in deze publicatie (als ook de verschillende NMI-studies), kan voor elk perceel in kaart worden gebracht hoe de bodemkwaliteit bijdraagt aan de verschillende diensten.

Op wat grotere schaal ligt er potentie in de connectie tussen het 4-Return-model van landschapsbeheer (een natuurlijke, gemengde en economische zone in relatie tot rendement van 1) financieel kapitaal, 2) natuurlijk kapitaal, 3) sociaal kapitaal en 4) inspiratie (zie Ferwerda \& Schoenmaker, 2020; Bakker et al., 2020)) en het concept van de Kansenkaart (Verhoeven \& Ros, 2018a, 2018b), waarbij op basis van perceelskenmerken en gebiedsopgaven in kaart wordt gebracht hoe individuele bedrijven kunnen bijdragen aan de hierboven genoemde vormen van kapitaal.

Gezamenlijk bepalen bodem en water (dan wel de kenmerken van een perceel) welke potentie er is en beïnvloeden ze de gewenste transitie om kringlopen in de landbouw beter te sluiten. Met deze transitie wordt een vorm van landbouw gestimuleerd waarbij zo veel mogelijk gebruik wordt gemaakt van eigen hulpbronnen, in evenwicht en met respect voor de natuurlijke omgeving (bodem-, lucht-, wateren natuurkwaliteit, landschappelijke waarde, klimaat en dierenwelzijn). Het ultieme doel hierbij is dat waterkwaliteit en waterkwantiteit een even grote rol zullen spelen als de andere hierboven genoemde doelen. We zien hierbij potentie voor een regeneratieve, op ecologische kennis en gebiedsaanpak gebaseerde landbouw, waarbij de bedrijven zelf en met elkaar gestimuleerd worden om de connectie te maken met de draagkracht en potentie van het gebied.

In 2020 heeft een werkgroep rondom bodemwaarderingsinstrumenten nagedacht over mogelijkheden om prestaties van agrarische ondernemers voor een duurzame leefomgeving te kunnen belonen. Zij stellen voor dat er gewerkt kan worden met kritische prestatie-indicatoren (KPI) die integraal sturen op duurzaam bodembeheer (Erisman \& Verhoeven, 2020; Erisman et al., 2020). KPI's zijn integrale en resultaatgerichte indicatoren waaraan doelen gekoppeld kunnen worden voor functies waaraan bodembeheer kan bijdragen. KPI's vormen een integrale set die gezamenlijk de prestaties op bodem en leefomgeving weergeven en voldoen aan de voorwaarde dat:

- Ze gezamenlijk een duidelijke en aantoonbare relatie met bodem- en waterkwaliteit hebben en vergelijkbare informatie geven voor verschillende percelen en bedrijven.

- De set integraal is. Het gaat erom dat het ene niet ten koste gaat van het andere, maar dat door alle aspecten in samenhang te nemen de bodem- en waterkwaliteit versterkt wordt.

- Aan de KPI's een streefwaarde verbonden is en op ieder bedrijf een nulmeting als ook het handelingsperspectief helder is. De streefwaarde is daarbij gekoppeld aan een of meerdere doelen.

- KPI's beïnvloedbaar moeten zijn door het nemen van maatregelen en bij voorkeur ook snel, goedkoop en betrouwbaar beschikbaar te maken zijn met minimale administratieve lasten.

In 2020 heeft een brede groep van experts en adviseurs dit verder concreet gemaakt voor het thema waterkwaliteit. Op basis van een evaluatie van huidige tools en instrumenten binnen het DAW (Ros et al., 2020b) en een inventarisatie van gebruikerswensen wordt geadviseerd om kennis over nutriënten in de bodem alsook de effectiviteit van maatregelen in te bedden binnen drie strategische ontwikkellijnen:

1. Gebruik een kwalitatieve adviesstool voor bedrijven om agrariërs en hun adviseurs te faciliteren in de keuze voor effectieve maatregelen die bijdragen aan schoon grond- en oppervlaktewater. Hiervoor kunnen huidige tools zoals de BodemScan, het BodemWaterPlan, het BedrijfsWaterPlan, de Maatregel-Op-De-Kaart en de Open-Bodemindex worden gefuseerd, voortbouwend op de ontwikkeling van het BBWP in provincie Noord-Brabant. De focus ligt op advisering van maatregelen, de mogelijkheid van feedback en niet op kwantitatieve evaluatie van effecten. 
2. Gebruik een kwantitatieve bedrijfstool om inzicht te geven in de impact van maatregelen binnen een bedrijfscontext. De focus ligt hier niet op advisering van maatregelen, maar op de borging en kwantificering van impact. Hiervoor kunnen de huidige BedrijfsWaterWijzer, de KringloopWijzerBodem en Hydrometra worden gekoppeld. Voor de toekomst is daarbij een uitbreiding gewenst richting andere sectoren. Mogelijk ligt hierbij zelfs een potentiële koppeling met de Afrekenbare Stoffenbalans zoals deze door commissie Remkens wordt voorgesteld als oplossing voor de huidige stikstofcrisis.

3. Gebruik een gebiedstool om op gebiedsniveau uitspraken te doen over de haalbaarheid en effectiviteit van maatregelen gegeven de beleidsopgaven en relateer dat aan de informatie rond en advisering van maatregelen uit de twee bedrijfsmatige tools. 


\section{Literatuur}

Akker, C. van den et al. (2012) Risico op ondergrondverdichting in het landelijk gebied in kaart. Alterra-rapport 2409, 80 pp.

Anonymus (2019). Inventarisatie provinciale aanpakken voor klimaat en landbouw., Wageningen.

Arcadis (2019). Waterkwaliteitsstudie KRW wateren Noorderzijlvest. Technisch rapport Waterschap Noorderzijlvest.

Bakker, Martha, Jan Phillip Witte, Gerard Ros, Wim de Vries, Bardia Mashhoodi, Sjerp de Vries, Hans Kros \& Tom Kuhlman (2020) Een ruimtelijke visie voor het landelijk gebied. Milieu. In press.

Boderie, P., W. Altena, E. Meijers, L. Kramer en R. Wortelboer (2021). Regionale pilot Kennisimpuls Rijn-Noord. Deltares rapport 11202710-002-ZWS-0007.

Boekel, E. M. P. M. van, P. Groenendijk en L.V. Renaud (2017). Maatregelen voor het verlagen van de nutriëntenbelasting uit landbouwpercelen: effecten van landbouwkundige maatregelen op de nutriëntenbelasting van het oppervlaktewater in zes polders in het beheergebied van Wetterskip Fryslân, rapport 2824, Wageningen Environmental Research, Wageningen.

Bolt, F.J.E. van der; T. Kroon, P. Groenendijk, L.V. Renaud, J. van den Roovaart, C.M. Janssen, S. Loos, P. Cleij, A. van den Linden en A. Marsman (2020). Het Landelijk Waterkwaliteitsmodel: Uitbreiding van het Nationaal Water Model met waterkwaliteit ten behoeve van berekeningen voor nutriënten. Wageningen: Wageningen Environmental Research rapport 3005 - 220.

Bruggen, C. van, A. Bannink, C.M. Groenestein, J.F.M. Huijsmans, L.A. Lagerwerf, H.H. Luesink, S.M. van der Sluis, G.L. Velthof en J. Vonk (2019). Emissies naar lucht uit de landbouw in 2017: berekeningen met het model NEMA. WOt-technical report 147, Wageningen, Wettelijke Onderzoekstaken Natuur \& Milieu. https://doi.org/10.18174/499382

Erisman JW \& F Verhoeven (2020) Integraal op weg naar kringlooplandbouw 2030 - Een voorstel voor kritische prestatie indicatoren systematiek. Bunnik. LBI-rapport 2020-010 LbP.

Erisman JW, Koopmans C, Zanen M, Van Eekeren N \& J Wagenaar (2020) Prestatie-indicatoren voor landbouwbodems. Landschap 2020/4, 223-229.

Ferwerda W \& D Schoenmaker (2020) Financiële sector kan transitie naar duurzame landbouw versnellen. ESG 105, 106-110.

Gaalen, F. van, L. Osté en E. van Boekel (2020). Nationale analyse waterkwaliteit. Onderdeel van de Delta-aanpak Waterkwaliteit. PBL-publicatienummer: 4002, The Hague, PBL Planbureau voor de Leefomgeving https://www.pbl.nl/sites/default/files/downloads/pbl-2020-nationale-analysewaterkwaliteit-4002_0.pdf

Gerven, L.P.A. van, Jansen, S., Groenendijk, P. (2019). Maatregel op de Kaart (Fase 1), identificeren van kansrijke landbouwmaatregelen per perceel voor schoner grond- en oppervlaktewater. Kennisimpuls Waterkwaliteit notitie.

Gerven, Luuk van, Stefan Jansen, Arnaut van Loon, Saskia Lukacs, Frank Verhoeven, Debby van Rotterdam en Piet. Groenendijk (2020): 'Maatregel op de kaart, kansrijke landbouwmaatregelen per perceel voor schoner grond en oppervlaktewater'. H2O, 8 januari 2020.

Gevaert, A. en M.J. Waterloo (2019). Waterschap Hunze en Aa's. Topsoil Duurzame waterkwaliteit Drenthe. Effecten van klimaat- en beheerscenario's op de export van nutriënten en gewasbeschermingsmiddelen in de stroomgebieden van de Drentsche Aa en de Hunze., Ref.: 1603390A00-R19-710, RPS advies- en ingenieursbureau bv.

Griffioen, J., R. Heerdink, L. Maring, S. Vermooten, D. Maljers en J. Hettelaar (2006). Enkele lithologische en (hydro)geochemische karakteristieken van de ondergrondparametrisering in het landelijke nutriëntenemissiemodel STONE. TNO-rapport 2006-U-R0161/A.

Grift B. van der, K. Klein, N. de Boorder en J.C. Rozemeijer (2011) Grondwaterbijdrage aan oppervlaktewaterkwaliteit in de Drentse Aa en Schuitenbeek. Deltares rapport 1202790-000-BGS0009.

Grinsven, J.J.M. van, A. Tiktak en C.W. Rougoor (2016) Evaluation of the Dutch implementation of the nitrates directive, the water framework directive and the national emission ceilings directive, NJAS - Wageningen Journal of Life Sciences, Vol 78, Pages 69-84. 
Grinsven H. van en A. Bleeker (2017) Evaluatie Meststoffenwet 2016: syntheserapport. PBL-rapport 2258, $196 \mathrm{pp}$.

Groenendijk, P., E. van Boekel., L. Renaud, A. Greijdanus, R. Michels en T. de Koeijer (2016). Landbouw en de KRW-opgave voor nutriënten in regionale wateren: het aandeel van landbouw in de KRW-opgave, de kosten van enkele maatregelen en de effecten ervan op de uit- en afspoeling uit landbouwgronden, rapport 2749, Wageningen Environmental Research, Wageningen.

Groenendijk, P., E. van Boekel en L. van Gerven (2021). Maatregelen op en rond landbouw-percelen ter vermindering van de uit- en afspoeling van nutriënten. Achtergrondinformatie over maatregelen ten behoeve van de Nationale Analyse Waterkwaliteit. Kennisimpuls Waterkwaliteit rapport 2021 (in press).

Groenendijk, Piet, Luuk van Gerven, Peter Schipper, Stefan Jansen, Simon Buijs, Arnaut van Loon, Saskia Lukacs, Frank Verhoeven, Bart Housmans, Debby van Rotterdam, Gerard Ros, Koos Verloop en Gert-Jan Noij (2021). Maatregel op de Kaart (Fase 2). Identificeren van kansrijke perceelsmaatregelen voor schoner grond- en oppervlaktewater. Kennisimpuls Waterkwaliteit rapport 2021.

Hattum, T. van et al. (2011) P-reducerende maatregelen in het stroomgebied van de Hunze; inventarisatie van de meest kosteneffectieve P-reducerende maatregelen in het stroomgebied van de Hunze. Alterra-rapport 2183, 84 pp.

Kros, Hans; Jaap van Jaap, Jan Cees Voogd, Piet Groenendijk, Cor van Bruggen, Romuald Molder en Gerard Ros (2019). Ruimtelijke allocatie van mesttoediening en ammoniakemissie: beschrijving mestverdelingsmodule INITIATOR versie 5. Wageningen: Wageningen Environmental Research, rapport 2939 - 95.

Molnar C (2018). Interpretable Machine Learning. A guide for Making Black Box Models Explainable. Open source publicatie, beschikbaar via https://christophm.github.io/interpretable-ml-book/

Prins, P. (2011). Boeren op weg naar klimaatbestendige productie: resultaten van het project Klimaat en landbouw in Noord-Nederland., Grontmij, Drachten.

Provincie Groningen, Drenthe, Fryslân, Waterschap Hunze en Aa's, Noorderzijlvest, Fryslân en Rijkswaterstaat Noord Nederland (2020). Afstemmingsnota Europese Kaderrichtlijn Water Rijn Noord, Nedereems en Eems-Dollard, Planperiode 2022-2027, Versie augustus 2020.

Ros, G.H., S. Verweij, N. Quist \& N. van Eekeren (2020a). Bedrijfsbodemwaterplan; maatwerk voor duurzaam bodem- en waterbeheer. Nutriënten Management Instituut BV, Wageningen, Rapport 1805.N.20, 33 pp.

Ros et al. (2018c) Advies nutriëntenvisie Rijn-Oost. Inventarisatie van knelpunten en oplossingen. NMI-rapport 1589.N18.21, 33 pp.

Ros G.H., L.P.A. van Gerven, P. Groenendijk, S. Damen, K. Verloop en M. de Haan (2020b). Strategisch plan voor de ontwikkeling van tools voor bewustwording en advies aan agrariërs voor verbeteren van waterkwaliteit. Kennisimpuls Waterkwaliteit Rapport.

Ros, G. H., H. Kros, P. van Vliet en K. van Duijvendijk (2018a). Kwantificering nutriëntensituatie van de bodem in het beheergebied van Waterschap Noorderzijlvest, Rapport 1708.N.17, Nutriënten Management Instituut NMI BV, Wageningen.

Ros, G. H., H. Kros, P. van Vliet en K. van Duijvendijk (2018b). Kwantificering nutriëntensituatie van de bodem in het beheergebied van Wetterskip Fryslân, Rapport 1708.N.17, Nutriënten Management Instituut NMI, Wageningen.

Ros, G. H. en S.E. Verweij (2019a). Bodem- en waterkwaliteit in het beheergebied van Wetterskip Fryslân. Deel 2. Ruimtelijke gebiedsanalyse, Rapport 1726.N.17, Nutriënten Management Instituut NMI bv, Wageningen.

Ros, G. H. en S.E. Verweij (2019b). Ontwikkeling maatwerkpakketten waterkwaliteit. Deel 1. Ruimtelijke gebiedsanalyse waterschap Hunze en Aa, Rapport 1742.N.18, Nutriënten Management Instituut NMI BV, Wageningen.

Ros, G. H. en S.E. Verweij (2019c). Ontwikkeling maatwerkpakketten waterkwaliteit. Deel 2. Gebiedsanalyse Hunze en Aa's voor N, P, en NH4, Rapport 1742.N.19, Nutriënten Management Instituut NMI bv, Wageningen.

Ros, G. H., J-C. Voogd, K. Brolsma en H. Kros (2019). Bodem-en bemestingskaarten Hunze \& Aa's, Rapport 1694.N.17, Nutriënten Management Instituut NMI bv, Wageningen.

Rozemeijer et al. (2016) Expertbeoordeling van landbouwmaatregelen voor oppervlaktewaterkwaliteit. H2O / 28 november 2016, 6 pp. 
Rozemeijer et al. (2018) Monitoring voor een gebiedsgerichte aanpak van nutriënten. Water Matters juni 2018, 4 pp.

RPS \& Acacia Water (2019). Waterschap Hunze en Aa's. Topsoil Duurzame waterkwaliteit Drenthe. Rapportage classificatie bodem en grondgebruik SWAP/SWAT., Referentienr. 16033900A100-R19226, RPS advies- en ingenieursbureau bv.

Schaap, B. (2009). Klimaat en landbouw Noord-Nederland: rapportage van fase 2, PRI Nota 629, Plant Research International, Wageningen.

Schipper, P. N. M. (2017). Nutriëntenbelasting gw-ow Rijnnoordoosteems., WEnR brief 10 okt 2017 Wageningen.

Schipper, P., E. van Boekel, E. Gies, P. Groenendijk, L. Jeurissen, H. Kros, L. Renaud en J.C. Voogd (2021). Landbouw en de KRW-opgave voor nutriënten in stroomgebied Maas, Opgave voor landbouw en de potentie van maatregelen voor het behalen van doelen. Wageningen Environmental Research, rapport 3046, 134 blz.

Smits, M.-J., N. Polman, R. Michels, R. Schrijver, W. Sukkel, A. Visser, T. Vogelzang en F. Kistenkas (2019). Natuurinclusieve landbouw: van niches naar mainstream (fase 1), nota 2019-033, Wageningen Economic Research, Wageningen.

Staveren, G. van en J. Velstra (2012). Verzilting van de landbouwgronden in Noord Nederland in het perspectief van de effecten van de klimaatverandering, KlimaatvoorRuimte (KvR).

Velthof et al. (2018) Wettelijk instrumentarium voor landbouwmaatregelen om waterkwaliteit te verbeteren. Realisatie van nutriëntendoelstellingen uit de Kaderrichtlijn Water. WOt-rapport 129, $118 \mathrm{pp}$.

Verhoeven F \& GH Ros (2018a) Kansenkaart Waterkwaliteit: slimme combinaties. V-Focus februari 2018.

Verhoeven F \& GH Ros (2018b) Kansenkaart 1.0: slimme combinaties. V-Focus oktober 2018.

Verloop, Koos; Maaike van Agtmaal, Wim Bussink, Nick van Eekeren, Piet Groenendijk, Stefan Jansen, Gert-Jan Noij en Marleen Zanen (2018). Achtergronden bij informatie in de BOOT-lijst factsheets. Wageningen Plant Research, Business unit Agrosysteemkunde, Rapport WPR 842.

Vries, W. de, H. Kros, J.C. Voogd, K. van Duijvendijk en G.H. Ros (2018). Kansen voor het sluiten van de mineralenbalansen in Noord-Nederland: effecten op regionale schaal en bedrijfsschaal., rapport 2925, Wageningen Environmental Research, Wageningen.

Westerhof et al. (2016) Nutriënten op hun plek. Arrangementen van waarde voor voedselproductie, bodem en water. ORG-ID, $71 \mathrm{pp}$.

Wit, J. de, D. Swart en E. Luijendijk (2009). Klimaat en landbouw Noord-Nederland: 'effecten van extremen', Grontmij Nederland BV, Houten. 


\section{Bijlage 1 Toelichting model STONE}

STONE is een simulatiemodel dat wordt gebruikt om nitraatconcentraties in het grondwater en de uiten afspoeling van stikstof en fosfor uit landbouw- en natuurgronden te berekenen. Het is een consensusmodel dat in samenwerking met RIVM en RIZA is ontwikkeld voor landelijke beleidsevaluaties van het mest- en het waterbeleid. Daarnaast berekent STONE de fosfaataccumulatie en de posten van de $\mathrm{N}$ - en P-balans van de bodem. Door de koppeling aan INITIATOR kan STONE de effecten van diverse scenario's ten aanzien van de intensiteit van de veestapel, de aanwending van dierlijke mest en kunstmest en de verandering van landgebruik doorrekenen.

De keten van deelmodellen van het modelinstrumentarium is weergegeven in onderstaande figuur. De hydrologische informatie voor STONE wordt berekend met het gekoppelde SWAP/NAGROM-model waarin op basis van informatie over meteo, drainage en geohydrologie de vochthuishouding wordt gesimuleerd.

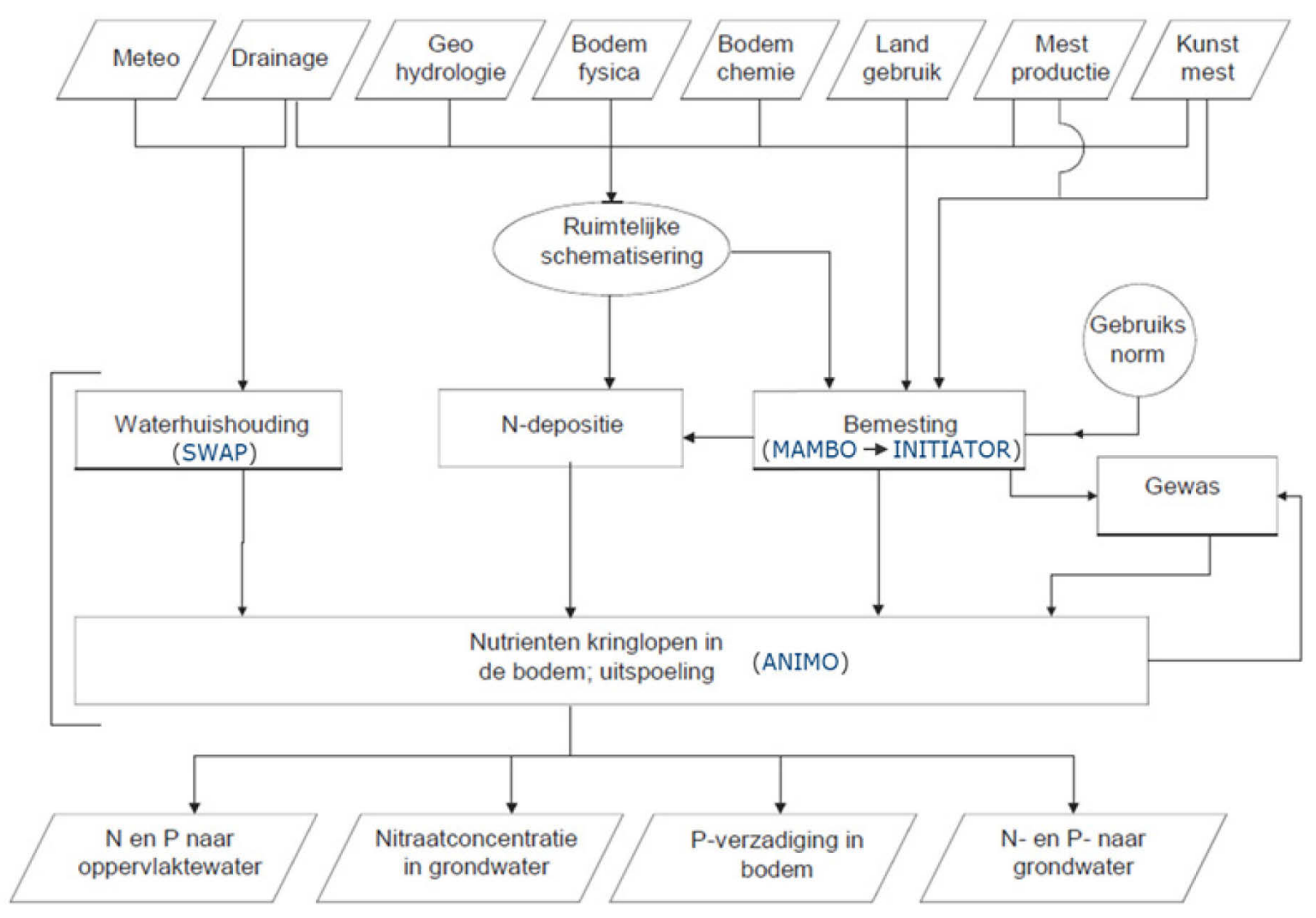

Figuur B1.1 Schema van rekenmodules en datastromen in STONE2.4.

De module ANIMO simuleert in STONE de nutriëntenhuishouding in de bodem en de resulterende uiten afspoeling naar water. ANIMO is een procesgericht model voor het simuleren van de kringloop van koolstof, stikstof en fosfor in de bodem, dat aanvankelijk is ontwikkeld voor toepassing op perceelniveau, maar ook geschikt is voor regionale toepassingen. Binnen STONE voert ANIMO de berekeningen uit voor clusters van rastercellen met een grootte van $250 \times 250$ m en met een tijdsstap van 10 dagen. Gerekend wordt in tijdseries van 15 jaar, waarbij de periode 1941-1970 wordt gebruikt om de modelkolommen te initialiseren. STONE omvat 6405 clusters (rekeneenheden) die verschillen in hydrologische en drainagekenmerken, landgebruik, bodemtype, bodemchemie en klimaat (meteodistrict). 
De opzet van die ANIMO-rekeneenheden is weergegeven in Figuur B1.2. Deze module simuleert de stikstof- en fosforprocessen in de grond en ondiep grondwater tot een diepte van $13 \mathrm{~m}$ en berekent de oppervlakkige afstroming en de $\mathrm{N}$ - en P-vrachten naar greppels, sloten en grotere wateren. Daarnaast wordt de uitspoeling van $\mathrm{N}$ en $\mathrm{P}$ naar dieper grondwater berekend en de nitraatconcentraties in de eerste meter van het grondwater. Geochemische processen in dieper grondwater en stromingsprocessen en biologische en chemische processen in oppervlaktewateren zijn niet inbegrepen.

Het model en toepassingen van het model zijn gepubliceerd in diverse rapporten en wetenschappelijke literatuur.

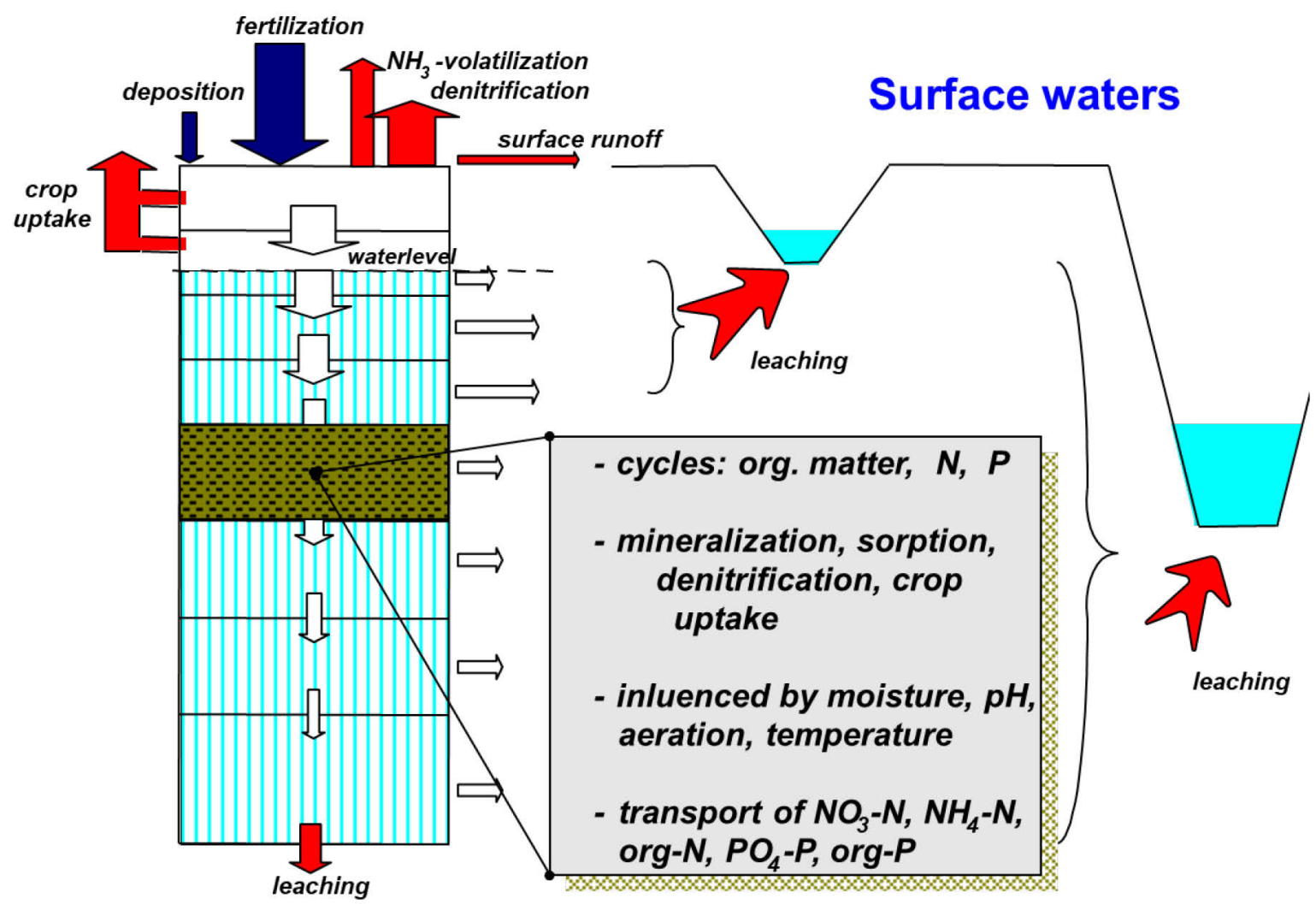

\section{Groundwater}

Figuur B1.2 Schematisch overzicht van de beschreven processen in het ANIMO-model. 


\section{Bijlage 2 Af- en uitspoeling stikstof en fosfor vanaf landbouwgronden}
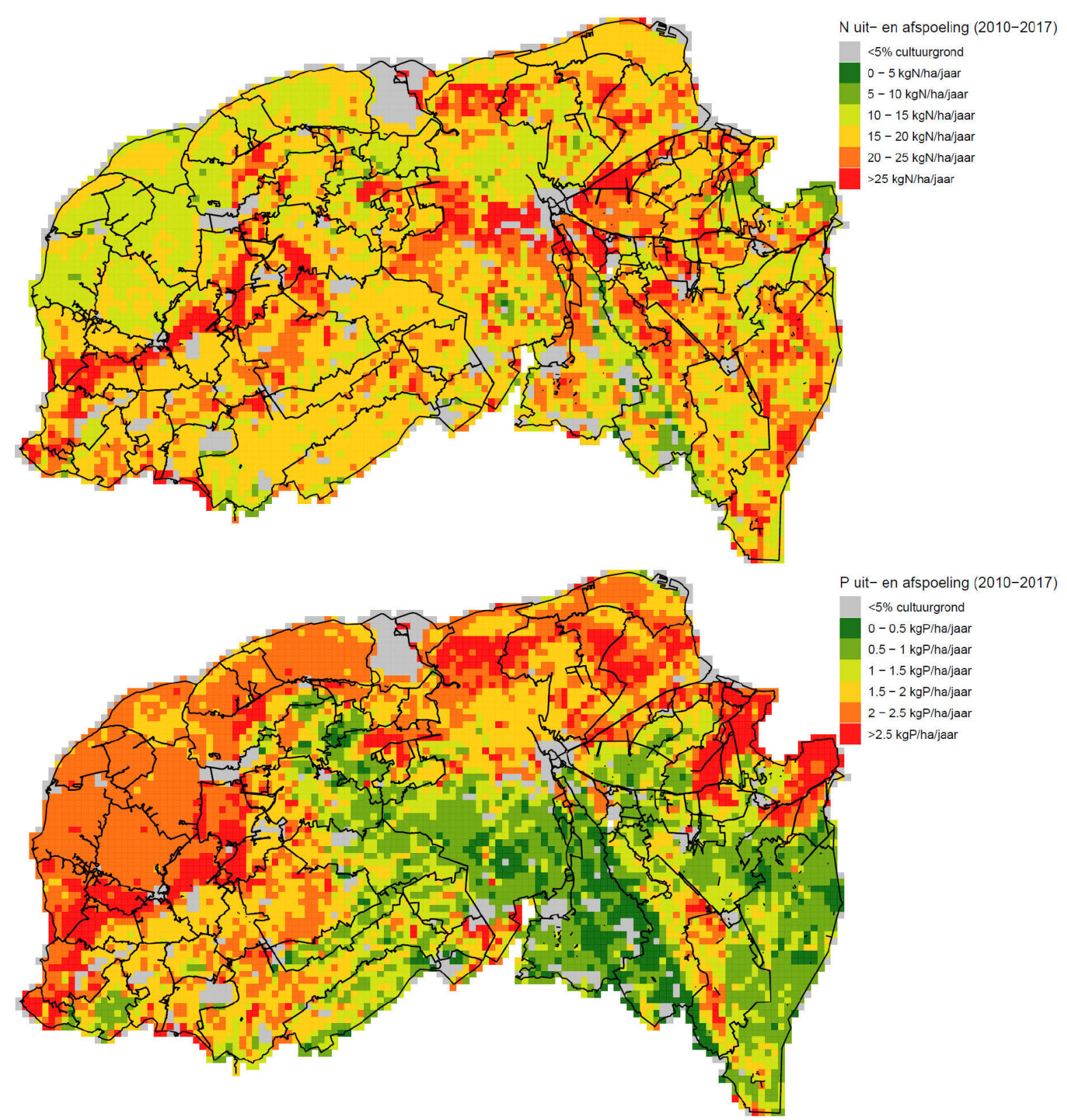

Figuur B2.1 Jaargemiddelde uit- en afspoeling van nutriënten vanuit cultuurgronden naar het oppervlaktewater, voor stikstof (boven) en fosfor (midden). Het gaat om resultaten van de rekenplots van het STONE-model na herschikking en aangepaste kwelconcentraties, gemiddeld over de periode 2010-2017. 
Wageningen Environmental Research Postbus 47

6700 AA Wageningen

T 0317480700

www.wur.nl/environmental-research

Wageningen Environmental Research Rapport 3094

ISSN 1566-7197
De missie van Wageningen University \& Research is 'To explore the potential of nature to improve the quality of life'. Binnen Wageningen University \& Research bundelen Wageningen University en gespecialiseerde onderzoeksinstituten van Stichting Wageningen Research hun krachten om bij te dragen aan de oplossing van belangrijke vragen in het domein van gezonde voeding en leefomgeving. Met ongeveer 30 vestigingen, 6.800 medewerkers ( $6.000 \mathrm{fte}$ ) en 12.900 studenten behoort Wageningen University \& Research wereldwijd tot de aansprekende kennisinstellingen binnen haar domein. De integrale benadering van de vraagstukken en de samenwerking tussen verschillende disciplines vormen het hart van de unieke Wageningen aanpak. 


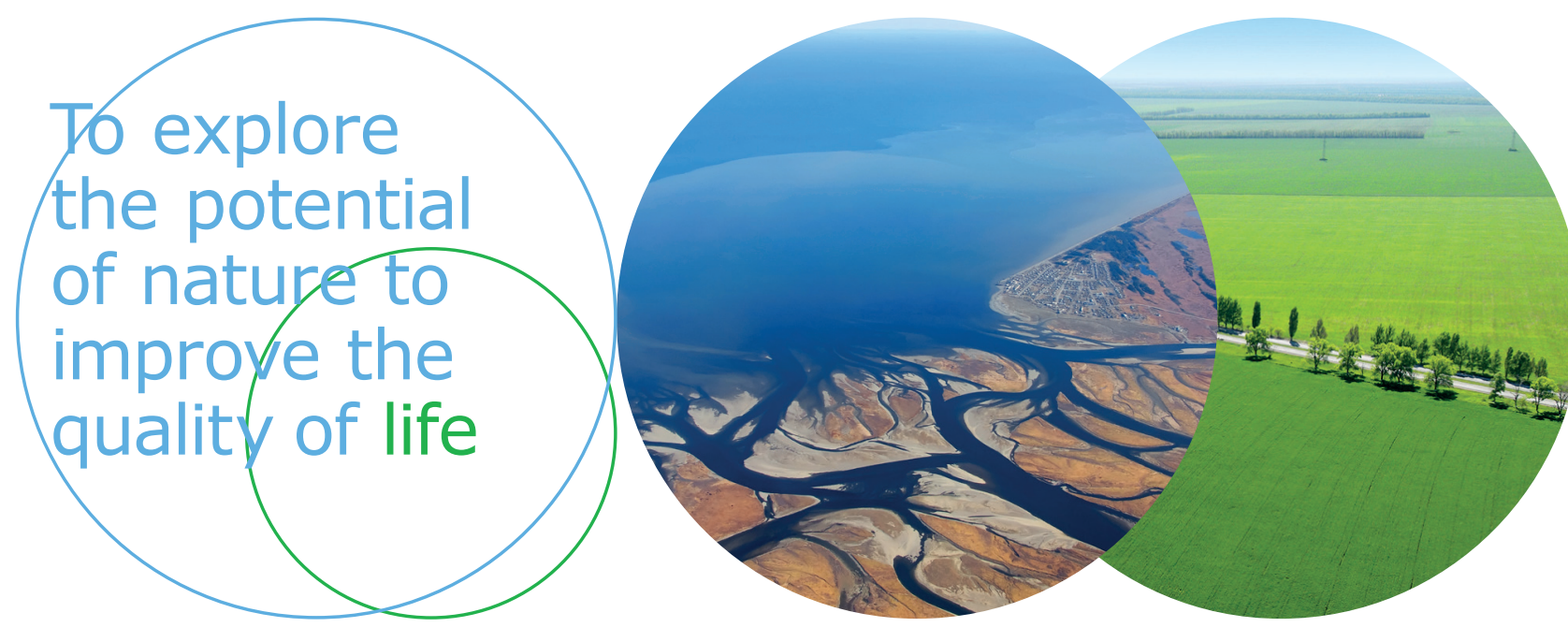

Wageningen Environmental Research Postbus 47

$6700 \mathrm{AB}$ Wageningen

T 317480700

www.wur.nl/environmental-research

Rapport 3094

ISSN 1566-7197
De missie van Wageningen University \& Research is 'To explore the potential of nature to improve the quality of life'. Binnen Wageningen University \& Research bundelen Wageningen University en gespecialiseerde onderzoeksinstituten van Stichting Wageningen Research hun krachten om bij te dragen aan de oplossing van belangrijke vragen in het domein van gezonde voeding en leefomgeving. Met ongeveer 30 vestigingen, 6.800 medewerkers (6.000 fte) en 12.900 studenten behoort Wageningen University \& Research wereldwijd tot de aansprekende kennisinstellingen binnen haar domein. De integrale benadering van de vraagstukken en de samenwerking tussen verschillende disciplines vormen het hart van de unieke Wageningen aanpak. 